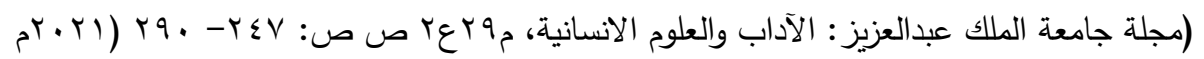

$$
\begin{aligned}
& \text { DOI:10.4197/Art.29-2.10 }
\end{aligned}
$$

\title{
دور الجامعات السعودية في تعزيز قيم المواطنة الرقمية (دراسة تحليلية للمواقع الإلكترونية للجامعات السعودية)
}

\author{
د. ظافر بن أحمد مصلح القرني \\ جامعة المجمعة - كلية التربية الزلفي
}

مستخلص. استهدفت الدراسة الحالية التعرف على درجة إسهام الجامعات السعودية في تعزيز قيم ومبادئ المواطنة

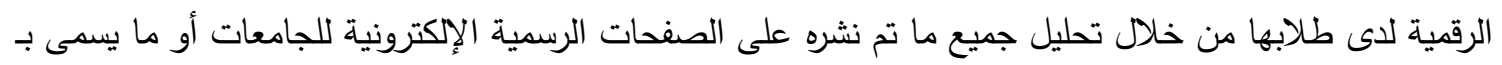

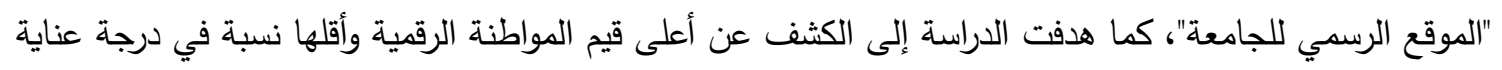

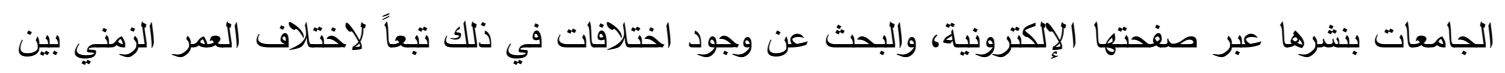
جامعة وأخرى، وقد اعتمد الباحث في تحليل الصفحات الإكترونية للجامعات على بطاقة خاصة قام بإعدادها تحقيقاً لأهداف الدراسة ،حيث اشتملت هذه البطاقة على المحاور التسعة الرئيسية لمبادئ المواطنة الرقمية، تم من خلالها استتتاج عدد من القيمة الفرعية لكل محور حيث استقر عددها بعد التحكيم من المختصين على(01) قيمة مواطنة رقمية، ثم قام الباحث بتطبيقها في مسح الصفحات الرسمية للجامعات السعودية الحكومية على شبكة الإنترنت ،البالغ عدئ

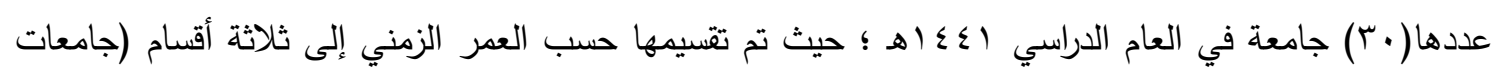
قديمة- جامعات متوسطة العمر - جامعات ناشئة)،وقد توصلت نتائج الدراسة إلى تقوق ثلاثة من مبادئ المواطنة الرقمية على باقي المبادئ التسعة وهي المبدأ الأول "الاتصال الرقمي" والثالث "التواصل الرقمي"، والخامس "اللياقة الرقمية"، وذلك يجسد الاهتمام الكبير للجامعات السعودية بتعزيز عناصر هذه المبادئ لاىى طلابها، كما أثبتت النتائج عدم وجود فروق ذات دلالة إحصائية تُعزى لاختلاف عمر الجامعات في إسهاماتها لتعزيز قيم ومبادئ المواطنة

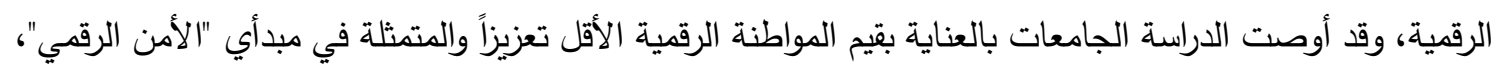

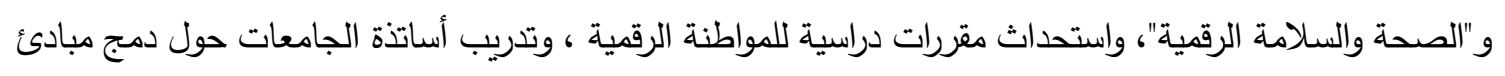
المواطنة الرقمية في المناهج الدراسية ، وإجراء المزيد من الدراسات حول إسهامات الجامعات السعودية في تعزيز قيم المواطنة الرقمية من خلال قنوات التواصل الاجتماعي المختلفة ك: تويتر ، وفيس بوك ، وسناء شئ شات، و وإجراء 
المزيد من الدراسات حول المقترحات والبرامج العملية التي يمكن من خلالها تعزيز دور الجامعات في نشر مبادئ المواطنة الرقمية في المجتمع السعودي على كافة مستوياته.

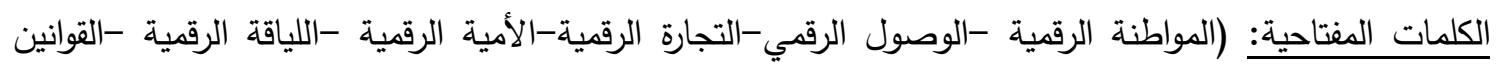
الرقمية -الحقوق والمسؤوليات الرقمية -الصحة والسلامة الرقمية -الأمن الرقمي).

الحصول على مصادر المعلومات ولجميع شرائح

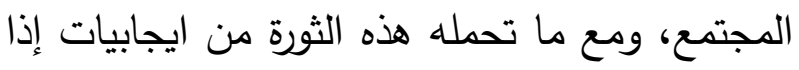

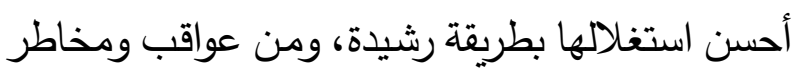

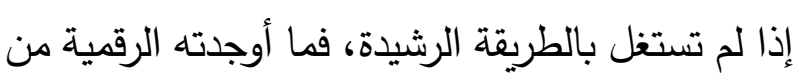

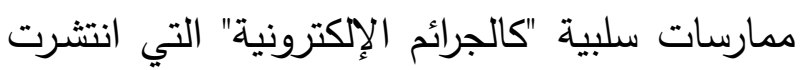

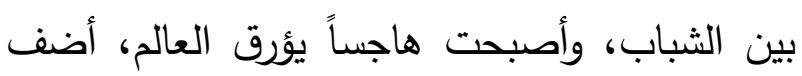
إلى تلك الممارسات المخدرات الرقمية، والإرهاب الإلكتروني، وغير ذلك من ممارسات نتيجة للاستخدام غير الرشيد للرقمية.

ومما يزيد الأمر خطورة إنه في غالب الأحيان تكون لأندان الفئات العمرية التي تستخدم التكنولوجيا الرقمية بشكل مفرط؛ هي الفئات العمرية الصغيرة من الأطفال

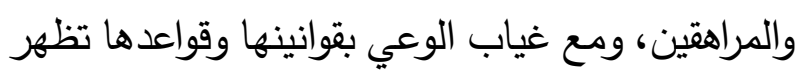
مشكلات وجرائم كثيرة قد تشكل خطراً على هذا الجيل.

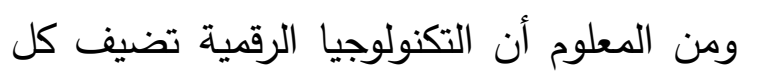

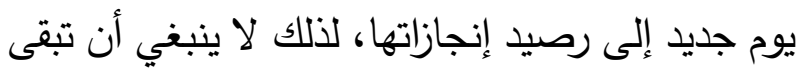

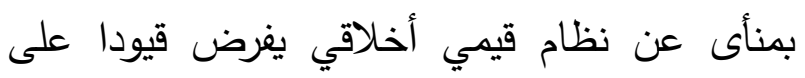
استخدامها لتحقيق الاستفادة القصوى من إمكاناتها،

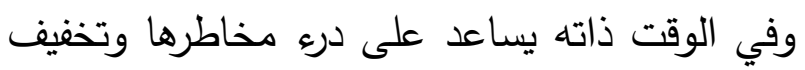
آثارها السلبية وأضرارها النفسية والاجتماعية، حيث أن داعل دأن

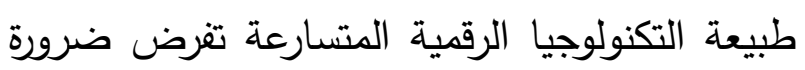

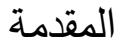

يلقب العصر الحالي بالعصر الرقمي الذي امتزجت

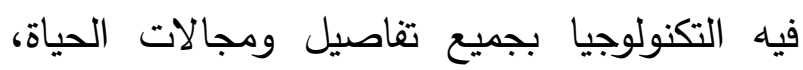
وأصبحت جزءً لا يتجزأ ومكوناً أساسياً من حياة الفرد والمجتمع، وأصبحت في متتاول أيدي الصغار قبل

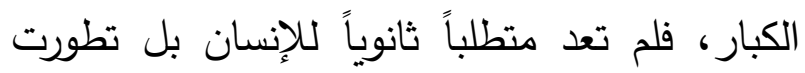
لتكون حاجة أساسية لا يَّتغنى عنها؛ واكتسبت أهمية بالغة في تسهيل عمليات التواصل الاجتماعي والتعليم والصحة والتجارة والأعمال .... وغيرها.

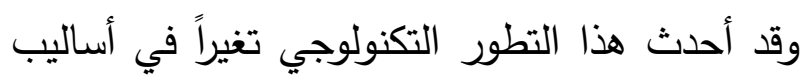
تعامل الناس مع بعضهم، ومفاهيم ومحددات المجتمعات عبر شبكات التواصل الرقمية، وظهرت

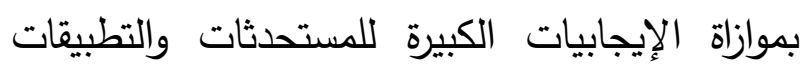
التكنولوجية؛ سلبيات متعددة، وممارسات غريبة، وأخلاقيات وأنماط تفكير دخيلة، حيث دخلت بعض السلوكيات المستحدثة على سلوكيات مجتمعاتتا الإسلامية الدحافظة مما أدى إلى انتشار أنواع حديثة

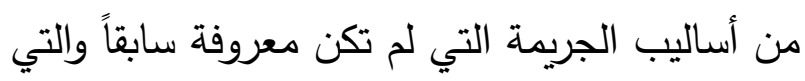
تدار بواسطة أيدٍ خفية خلف شاشات الأجهزة الإلكترونية.

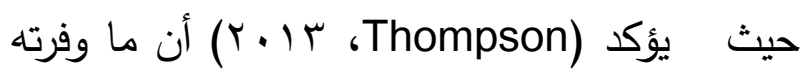
ثورة الاتصالات الرقمية من تسهيل وسرعة في 
حيث يشير (reurydice(ب)، إلى أن المواطنة الرقمية لها علاقة وطيدة بالتعليم، لأنها الوسيلة التي آني

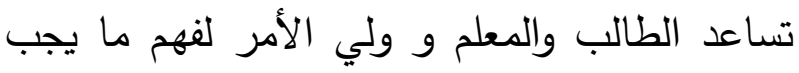
فهمه من أجل الاستخام الأمثل للتكنولوجيا، فهي وسيلة لإعداد الطالب للانخراط بالمشاركة في خذمة الإنة وطنه من خلال الاستخدام الأمثل لها، كما أن معظم

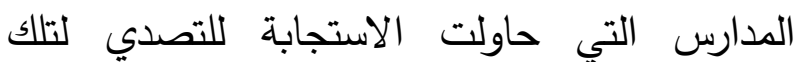
المشكلات بوضع سياسات تضمن قواعد لاستخدام

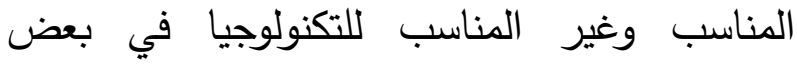
الدجتمعات الغربية تأثيراً محدوداً في السلوك المسؤول أثناء التعامل مع التكنولوجيا وأن التصدي الحقيقي للتغلب على تلك المشكلات يعتد بالدرجة الأولى على التى تزويد المتعلمين بالمعرفة وتعليم التقكير التأملي، ووضع الضوابط التي تسمح للتلاميذ فهم الكيفية المناسبة لاستخدام التكنولوجيا (Ribble\& Bailey)،

$$
\text { . (r...T }
$$

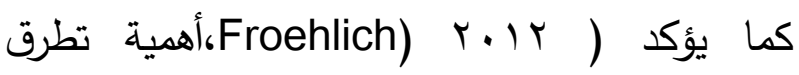
المؤسسات التعليمية المختلفة ولا سيما الجامعات لتعزيز مبادئ المواطنة الرقمية فهي تقدم أجيالاً من الثباب الذي يقع على عاتقه مسؤولية مجتمعية كبيرة من نشر ثقافات حضارية ومنهجية سليمة في التعامل مع التكولوجيا الرقمية وحماية أنفسهم ومن حولهم من مخاطرها بجانب الاستفادة منا تقدمه من خدمات للمجتمع، فلا شك أن نشر ثقافة المواطنة الرقمية في

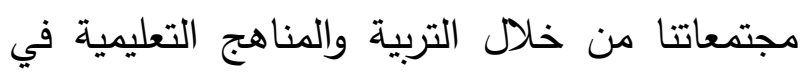
الدداس والجامعات أصبح من أساسيات الحياة
وجود قيم حاكمة وزاد أخلاقي للفرد في تعاملاته

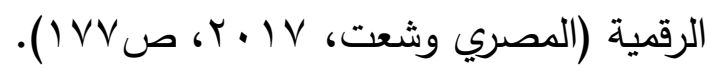
ومن هذا المنطلق ظهر مصطلح جديد أصبح يكتسب زخماً واهتماماً كبيرين في جميع أنحاء العالم وهو

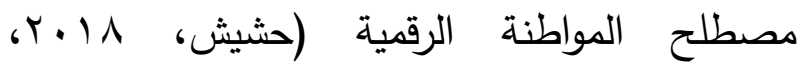
ص • (؟))، حيث تشكل المواطنة الرقمية نظام حماية لجميع الأفراد عند استخدام أجهزة الحاسب الآلي، والأجهزة المحمولة، وشبكة الإنترنت بصورة إيجابية، بحيث تسعى إلى إيجاد الشخصية المتكاملة للمواطن الرقمي الذي يحب وطنة، ويفكر لخدمته وحمايته، بعيداً عن الإساءة والتشهير بالآخرين، كما تعزز المواطنة الرقمية لبيئة إلكترونية إيجابية، أكثر أمناً وسلامة للجميع، وتعمل على توحيد الثقافة التقنية، وتوفير الأساس الذي يقوم عليه المجتمع الرقمي، ومحاولة تفهم المخاطر والمشكلات المحتملة، ومحاولة تقليل الفرص التي تجر الجيل إلى المشكلات من

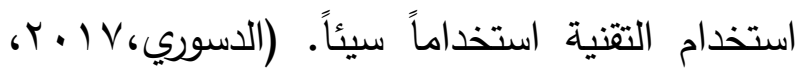

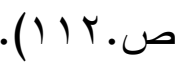
وبما إن المواطنة الرقمية جاءت مؤطرة بمبادئ وقيم وقوانين حاكمة؛ فان المؤسسات التعليمية عامة والجامعات خاصة جديرة بالاهتمام بها والسعي الحثيث لنشر ثقافتها وقوانينها بين طلبتها ومنسوبيها، خاصة في ظل التوجه الحديث للرقمنة وتوظيف البرامج والتطبيقات التكنولوجية في جميع المجالات الإدارية والتعليمية بالمدارس والجامعات. 
وعلى نحو آخر نجد أن دولاً متقدمة عديدة مثل بريطانيا والولايات المتحدة وكندا تدرس لطلابها في المدارس مواضيع خاصة بالمواطنة الرقمية في إطار منهج التربية الرقمية، كما نجد في نفس الإطار المشروع الذي وضعته أستراليا تحت شعار " الاتصال بثقة: تطوير مستقبل أستراليا الرقمي" والذي ينص على تصني تصني تعميم تدري المواطنة الرقمية للطلاب مع تدريب

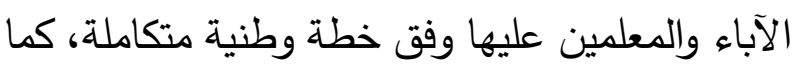
تخطط فرنسا لجعل موضوع المواطنة الرقمية قضية وطنية كبرى (القايد، ع ا ـ ب). جدير بالذكر إن ديننا الإسلامي الحنيف كان له قصب الهب

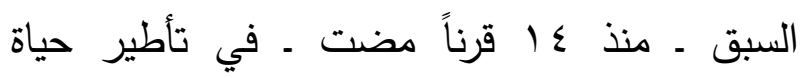
المجتمعات الإنسانية ورسم خارطة الطريق الواضحة لقوانين التعايش بين البشرية وأساليب التعامل مع الإنيه المستحدثات العلمية والاتصال والتواصل الإيجابي مع الآخرين سواءً كانوا من المسلمين أو غير المسلمين؛

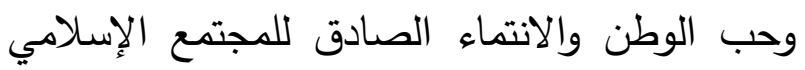
والدفاع عن ثوابت المجتمع والتعامل الواعي مع الأبع الآخرين، والصدق في البيع والثراء والوفاء بالعهود،

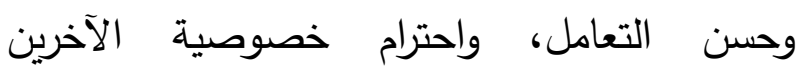
.....وغيرها من المعاني السامية التي يمكن إدراجها تحت مبدأ((حسن الخلق))، والذي يلتقي مع مبادئ وقيم المواطنة الرقمية الحديثة التي تشكلت مع التطور التكنولوجي الحديث في بيئات ومجتمعات الاتصال والتواصل الرقمي، فقد جاء ذلك في مواطن عدة من

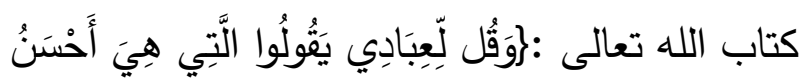

وضرورة ملحة يجب أن تتحول إلى مشاريع وبرامج تربوية بالتعاون مع مبادور مبات المجتمع المدني والمؤسسات الإعلامية حتى نتمكن من حماية مجتمعاتتا من الآثار السلبية للتكنولوجيا وتحفيز الاستفادة المثلى منها للمساهمة في بناء الاقتصاد الرقمي الوطني. وقد اتجهت الجامعات السعودية ـ بفضل الله ـ. في العقدين الأخيرين إلى التحول التقني والاستفادة من الثورة الرقمية بدرجة كبيرة فتم توظيف البرامج التقنية في التعاملات الإدارية في شؤون الموظفين، والطلبة، وشؤون أعضاء هيئة التدريس ، وتم توظيف منصات التواصل وقنوات الاجتماعي المختلفة كتويتر

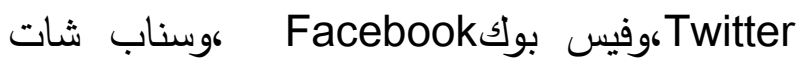
Snap chat للجامعات ...؛لنقل الأخبار والفعاليات والتواصل مع المسؤولين كبدائل للتعاملات الورقية السابقة ، كما تم إدماج التعليم الإلكتروني بأنماطه المختلفة الكلي ،والجزئي، والمتمازج في التعليم الجامعي، مما أدى بالهري

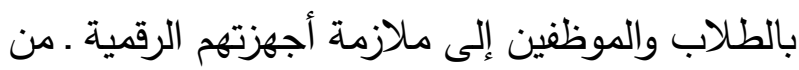
أجززة حاسوب أو هواتف ذكية ـ لأوقات طويلة داخل

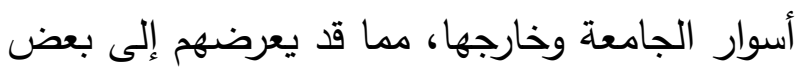
الإشكالات النفسية والفكرية، والجسدية، والاجتماعية

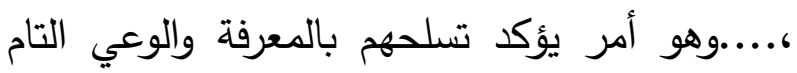

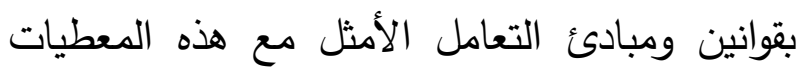
التكنولوجية من جميع النواحي وذلك يتمثل في معرفة مبادئ وقيم المواطنة الرقمية. 


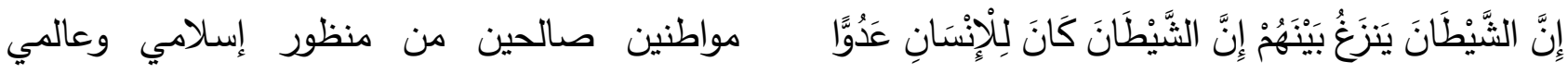

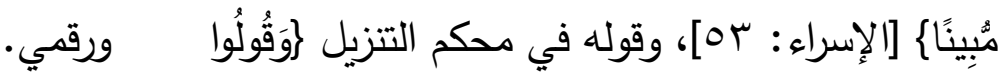

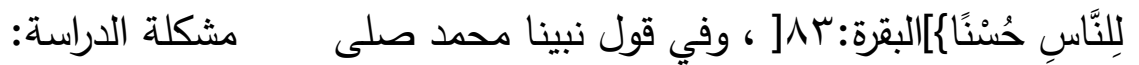
تناولت عدد من الدراسات العربية والأجنبية موضوع مُنك المواطنة الرقمية من جوانب محتفلة؛ حيث أكدت

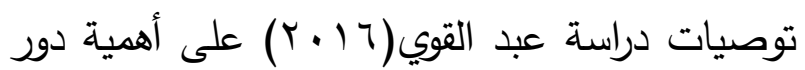
الجامعات في توعية الطلاب بحقوقهم وواجباتهم الرقمية، وأضافت دراسة الجزار (ع ا ب ب) أهمية دور المؤسسات التربوية في غرس قيم المواطنة الرقمية ودور المؤسسة والمعلمين والمتعلمين في هذه الخطة،

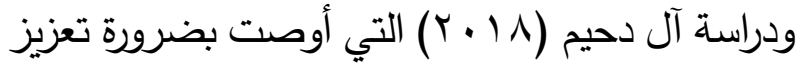
قيم المواطنة الرقمية لدى مدربي التدربب التربوي وتضمينها في المقررات الدراسية في المرحلة الجامعية،

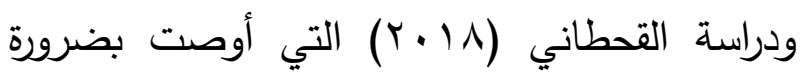
العمل على تحقيق وتفعيل قيم المواطنة الرقمية المتضمنة في مقرر تقنيات التعليم، ودراسة الحافظي

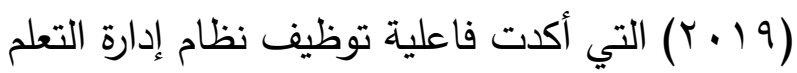
في تتمية قيم المواطنة الرقمية (Black board) ومهارات التفكير التأملي لدى طلاب كلية التقنية Dottere ) بمدينة جدة، ودراسة دويتيرر وآخرون

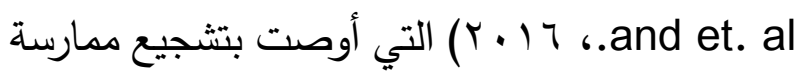
المواطنة الرقمية في مجالات التعليم المختلفة بالولايات المتحدة الأمريكية، وتسليط الضوء على مزايا وفوائد تدريس المواطنة الرقمية للشباب، ودراسة بيراردي

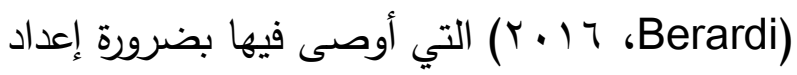
المعلم ليكون مستعدا للتربية على الرقمية، إلا إنه -

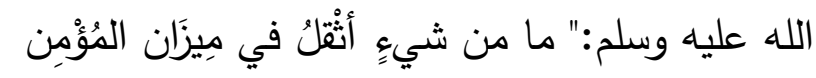

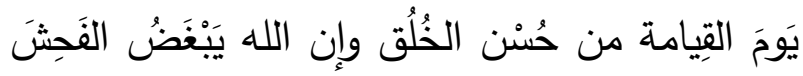
البذِيّ" وقوله صلي الله عليه وسلم كذلك :" المُسْلُِِ مِنْ

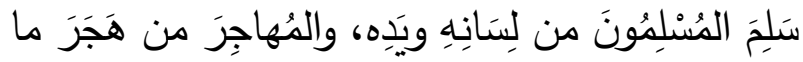
نهى الله عَنْهُ" وليس أدل من اعتبار حسبِ حسن أخلاق المسلم شرط لاكتمال إسلامه، إلا حرص الإسلام على حسن الخلق ولين القول احترام الآخرين والإحسان إليهم حتى في مواضع الخلاف. والأدلة كثيرة من الكتاب والسنة على عنى عناية الثارع

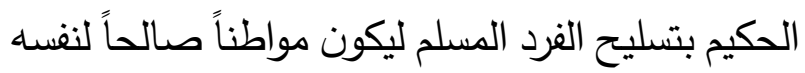
في العناية بصحته وسلامته الجسدية والفكرية كمؤشر على قيم الصحة والسلامة الرقمية، وفي مجال التجارة كمؤشر على قيم التجارة الرقمية، والقوانين الرقمية،

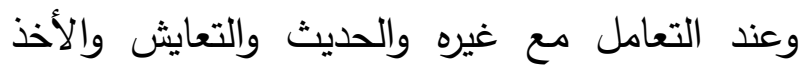
والطلب كمؤشر على قيم اللياقة الرقمية، والاتصالات الرقمية، ومن جانب معرفة ماله وما عليه وتحمل مسؤولية ذلك كمؤشر على قيم الحقوق والمسؤوليات الرقمية، والحث على تعلم كل جديد والاستفادة منه كمؤشر على قيم محو الأمية الرقمية، والحذر والوعي بالمخاطر وتقديرها كمؤشر على قيم الأمن الرقمي

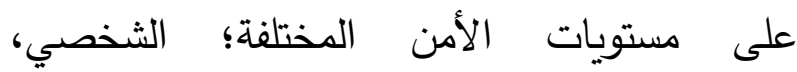
والاجتماعي، والوطني، وما إلى ذلك من القيم التي حرص الإسلام على تربية المسلمين عليها ليكونوا 
العمل بعد التخرج والمساهمة الفاعلة في بناء المجتمع والقدرة على الحماية الثخصية والوطنية المناسبة متسلحاً في ذلك بالدين والعلم والفكر القويم .من هنا جاءت فكرة أو (مشكلة) هذه الدراسة لتسليط الضوء على دور الجامعات السعودية في تعزيز مبادئ المواطنة الرقمية من خلال ما يتم نشره على الصفحات الرسمية للجامعات على الإنترنت من خلال رصد كافة الفعاليات والبرامج والأخبار ذات العلاقة بالمواطنة الرقمية ومبادئها التسعة، ومن ثم تقديم التوصيات المبنية على نتائج الدراسة التحليلية سعياً للعناية بهذا الجانب المهم من جوانب دور الجامعات السعودية المنوطة بها في إعداد المواطن الصالح لنفسه ولوطنه ومجتمعه، والقادر على المساهمة الفاعلة في التتمية والإنتاجية والمنافسة العالمية في شتى مجالات العمل

والحياة المختلفة. أسئلة الدراسة:

تسعى الدراسة للإجابة على التساؤل الرئيس التالي: "ما دور الجامعات السعودية في تعزيز قيم المواطنة الرقمية؟" ويتقرع من السؤال الرئيس التساؤلات الفرعية

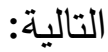

ا . ما درجة تعزيز الجامعات السعودية لقيم "

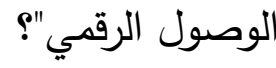

r. ما درجة تعزيز الجامعات السعودية لقيم " التجارة

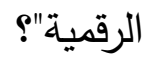

". ما درجة تعزيز الجامعات السعودية لقيم "

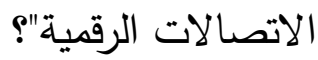

وفي حدود علم الباحث - لم تتناول أي من الدراسات السابقة دور الجامعات السعودية في تعزيز مبادئ المواطنة الرقمية من خلال ما ينشر عبر قنوات التواصل الاجتماعي خاصة الصفحات الرسمية للجامعات، من جانب آخر ومن خلال خبرة الباحث في مجال التدريس الجامعي والتعامل مع طلبة أكثر من جامعة وفي تخصصات مختلفة ومن خلال تدريس عدد من مساقات تكنولوجيا التعليم ؛ فقد لاحظ تكرز استخدام الطالب الجامعي على توظيف التقنية في مجالات الترفيه، والبحث عن الأخبار الرياضية وأخبار آخر الصيحات الثبابية من ملبوسات وألعاب ... وغيرها ، وفي المقابل هناك ضعف واضح في توظيف التقنية في مجالات البحث العلمي، وتعلم المهارات الحياتية المختلفة واللغات، ومهارات التفكير والتعلم، كما أن الطلبة يفتقرون إلى الوعي بقوانين التواصل والت التهات الرقمية ومهارات وفنيات التعامل الإيجابي مع ما ليات يقرأونه في صفحات الإنترنت ؛ من أخبار كثيرة وإعلانات وشائعات وما يواجهون من حسابات وهمية لأشخاص أو منظمات مجهولة منها ما يدعو يونات للإرهاب، ومنها ما يسوق لمنتجات إباحية وتجارة

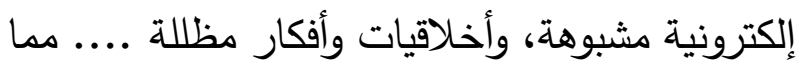
قد يؤدي بالثباب إلى الانحراف والتخلق بمثل هذه الأخلاقيات السيئة، أو يعرضهم للابتزاز ، أو يجندهم ضد مجتمعاتهم وبلدانهم، في حين إن الطالب الجامعي يتوقع منه أن يكون معداً إعداداً مهنياً إندان

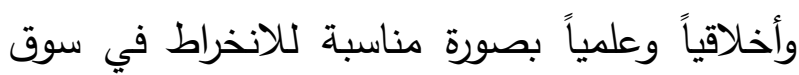


0. الكثف عن وجود اختلافات في نسب توافر قيم المواطنة الرقمية في صفحات الجامعات السعودية الرسمية تبعاً لاختلاف عمر الجامعة (قديمة - حديثة فعيه - ناشئة) أهمية الدراسة: 1. تسعى الدراسة للمساهمة في التقدم بدور الجامعات السعودية في تحسين مخرجاتها وتخريج أجيال ذات كفاءة شخصية وعلمية ووطنية. r. ت تقدم الدراسة أداة لقياس توافر قيم المواطنة الرقمية

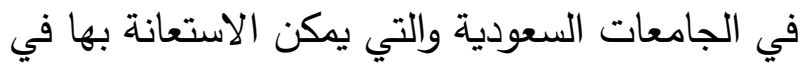
تقييم جامعات أُخر حول العالم. r. تقدم الدراسة إطار نظري يفيد في توجيه أنظار المختصين في الجامعات السعودية نحو أهمية تعزيز قيم المواطنة الرقمية لدى طلاب الجامعات. ع. تقدم الدراسة نتائج إحصائية حول مدى مراعاة الجامعات السعودية لقيم المواطنة الرقمية، وكيفية تعزيزها لتنمية هذه المبادئ التسعة. ه. تعمل هذه الدراسة على تحديد القيم التي لم تعززها مواقع الجامعات السعودية الناشئة على الإنترنت بصورة جيدة وواضحة. 7. تعمل هذه الدراسة على تحديد القيم الي ساهمت مواقع الجامعات السعودية الناشئة على الإنترنت بتعزيزها وتتميتها بصورة جيدة.

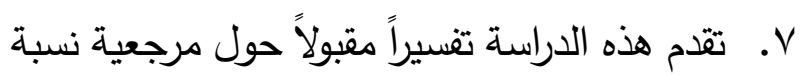
توافر قيم المواطنة الرقمية تبعاً لاختلاف العمر الزمني

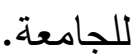

ء. ما درجة تعزيز الجامعات السعودية لقيم " محو

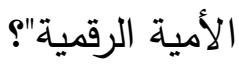
ه. ما درجة تعزيز الجامعات السعودية لقيم " اللياقة

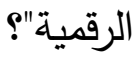
T. ما درجة تعزيز الجامعات السعودية لقيم " القوانين

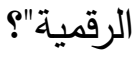
V. ما درجة تعزيز الجامعات السعودية لقيم " الحقوق لرق

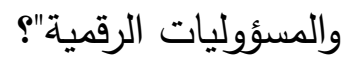
^. ما درجة تعزيز الجامعات السعودية لقيم " الصحة

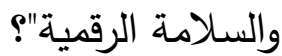
9. ما درجة تعزيز الجامعات السعودية لقيم" الأمن

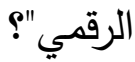
• ا.هل هناك فروق ذات دلالة إحصائية بين متوسطات درجات تضمين الجامعات السعودية لقيم المواطنة الرقمية في صفحتها الإكترونية الرسمية تعزى لمتغير العمر الزمني للجامعة؟ أهداف الدراسة: هدفت الدراسة الحالية إلى تحقيق الأهداف التالية: ا. التعرف على دور الجامعات السعودية في تعزيز قيم المواطنة الرقمية من خلال صفحاتها الرسمية. r. تصنيف الجامعات السعودية من حيث إسهاماتها في تعزيز قيم المواطنة الرقمية. r. الكشف عن قيم المواطنة الرقمية ذات النصيب الأعلى في عناية الجامعات السعودية بتنميتها. ء. الكثف عن قيم المواطنة الرقمية ذات النصيب الأقل في عناية الجامعات السعودية بتنميتها. 
• جامعات حديثة: وتضم الجامعات التي تأسست منذ أكثر من • ا سنوات وأقل من · r سنة، ويبلغ عددها

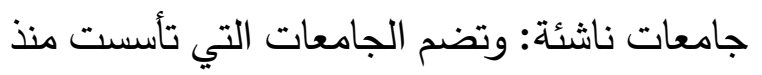

أقل من · إنوات، ويبلغ عددها ويبلغ عددها (^)

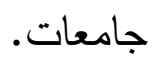

$$
\text { ويبلغ عددها (ع ا ) جامعة. }
$$

مجتمع الاراسة

يتمثل مجتمع الدراسة في كافة جامعات المملكة

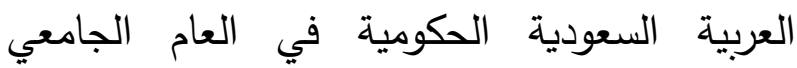

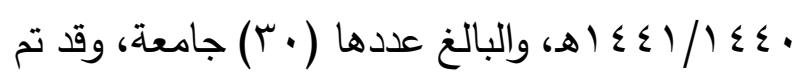
تقسيمها بحسب العمر الزمني منذ تاريخ التأسيس إلى إلى

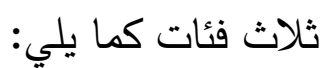

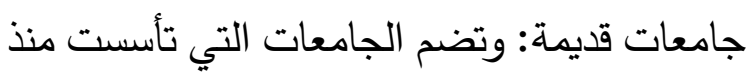

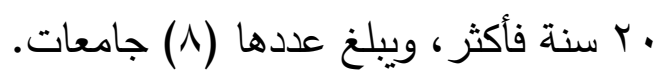
ويوضح الثكل (1) التصنيف التفصيلي لهذه الجامعات:

شكل (1) التصنيف التفصيلي للجامعات السعودية مصنفة حسب عمرها (مجتمع الدراسة)

\begin{tabular}{|c|c|c|c|}
\hline جامعات ناشئة & جامعات حديثة & جامعات قديمة & b \\
\hline الجامعة السعودية الإككترونية & جامعة الملك خالد & الجامعة الإسلامية بالمدينة المنورة & 1 \\
\hline جامعة الأمير سطام & جامعة الأميرة نورة & جامعة الملك سعود & 2 \\
\hline ل & جامعة الباحة & جامعة الملك عبد العزيز & 3 \\
\hline جامعة الملك عبد الرحمن بن فيصل & جامعة جوف & جامعة الامام محمد بن سعود & 4 \\
\hline جامعة بيشة & جامعة الحدود الشمالية & جامعة الملك فهد للبترول & 5 \\
\hline جامعة جدة & جامعة الطائف & جامعة الملك فيصل & 6 \\
\hline جامعة حفر الباطن & جامعة القصيم & جامعة أم القرى & 7 \\
\hline \multirow[t]{7}{*}{ جامعة شقراء } & جامعة الملك سعود للعلوم الصحية & \multirow[t]{7}{*}{ جامعة نايف للعلوم الصحية } & 8 \\
\hline & جامعة الملك عبد الله & & 9 \\
\hline & جامعة تبوك & & 10 \\
\hline & جامعة جازان & & 11 \\
\hline & جامعة حائل & & 12 \\
\hline & جامعة طيبة & & 13 \\
\hline & جامعة نجران & & 14 \\
\hline
\end{tabular}

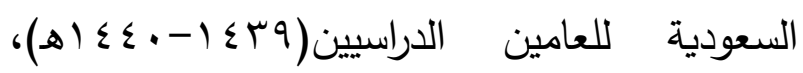

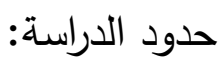
(ه) (ه $1 \leqslant 1-1 \leq \varepsilon \cdot)$

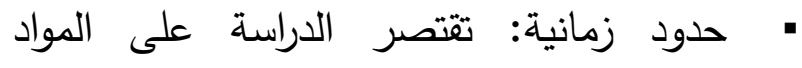

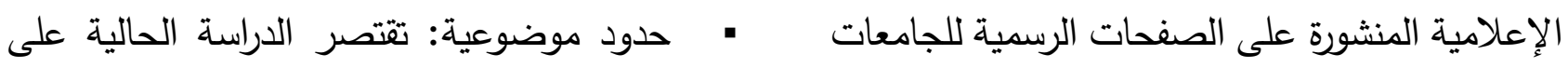

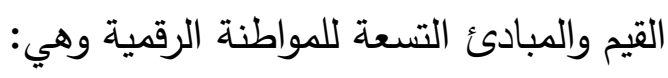


هي مجموعة المعتقدات والسلوكيات المرتبطة بمجموعة من المجالات القيمية الرقمية والتي يمكن من خلالها تحديد سلوك الفرد نحو الاستخدام الواعي والمسؤول في المجتمع الرقمي (الحافظي، 9 1. r،

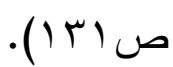

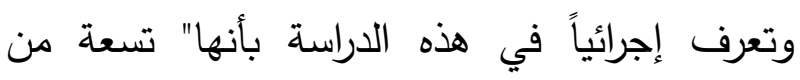
المبادئ الرئيسة التي تضم مجموعة القيم والسلوك فئون

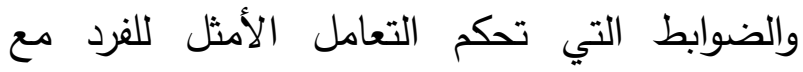
المعطيات التكنولوجية والمواقع والمنصات الرقمية وتسلحه بالعلم والمعرفة والأخلاق عند التعامل مع الأفراد والمؤسسات ومن خلالها وتوجه سلوكه نحو التصرف الأمثل مما يوفر له وللطرف الآخر الحماية

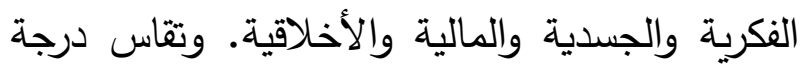
تتمية الجامعات لهذه القيم من خلال مقدار ما يتم نشره على صفحاتها الرسمية على الإنترنت من فعاليات وبرامج ضمن إطار مبادئ المواطنة الرقمية التسعة والقيم المندرجة تحتها. الفصل الثاني: أدبيات الدراسة والدراسات السابقة

\section{مفهوم المواطنة الرقمية:}

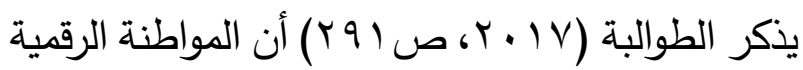

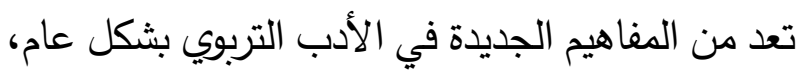
والأدب المتعلق بتربية المواطنة أو الأدب المتعلق لهن بموضوعات الدراسات الاجتماعية بشكل خاص، حيث

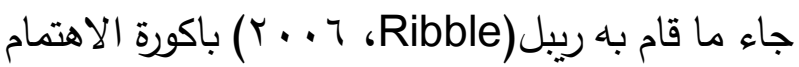
بهذا المفهوم فدافعه الأساسي لإظهار هذا المفهوم هو بها
- مبدأ الوصول الرقمي.

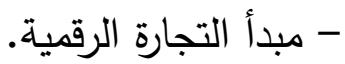
- مبدأ الاتصالات الرقمية. - مبدأ محو الأمية الرقمية. - مبدأ اللياقة الرقمية. - مبدأ القوانين الرقمية. - مبدأ الحقوق والمسؤوليات الرقمية. - مبدأ الصحة والسلامة الرقمية.

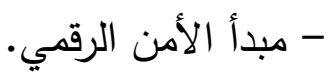
• تقتصر الدراسة على العناصر التفصيلية (O^) عنصراً، والمضدنة ببطاقة تقييم توافر قيم المواطنة الرقية بالصفحات الرسمية للجامعات السعودية. • تقتصر الدراسة على الجامعات السعودية الحكومية وعدد (·r) جامعة.

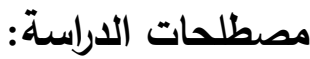
المواطنة الرقمية Digital Citizenship: تعرف المواطنة الرقمية بأنها مجموعة من المعايير والمهارات وقواعد السلوك التي يحتاجها الفرد عند التعامل مع الوسائل التكنولوجية، لكي يحترم نفسه ويحترم الآخرين، ويتعلم التواصل مع الآخرين، ويحمي

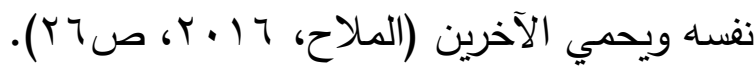
وهي مجموعة القواعد والضوابط والمعايير والأفكار والمبادئ المتبعة في الاستخدام الأمثل للتقنية التي

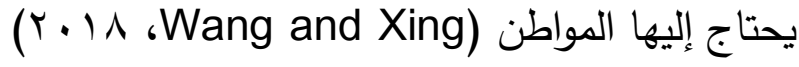

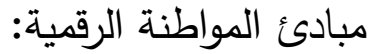


والتطبيقات وتحديد الدحاور التسعة التي تقوم على

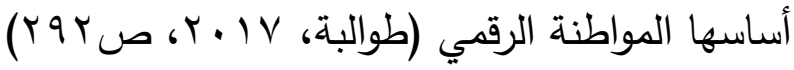
ويمكن تعريف المواطنة الرقمية بأنها قواعد السلوك الكئك

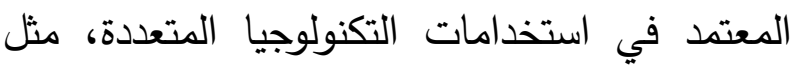
استخدام من أجل التبادل الإلكتروني للمعلومات، والمشاركة الإلكترونية الكاملة في المجتمع، وشراء وبيع البضائع عن طريق الإنترنت، وغير ذلك، وتعرف

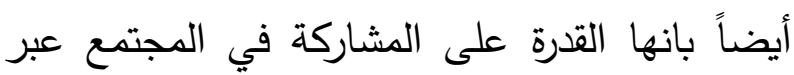
شبكة الانترنت، كما أن المواطن الرقمي هو الذي الني يستخدم الانترنت بشكل منتظم وفعال (مصطفى الانى الترني

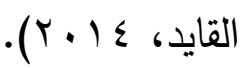
وقد عرفت المواطنة الرقمية بأنها توجيه وحماية، توجيه نحو منافع التتنيات الحديثة، وحماية من أخطارها

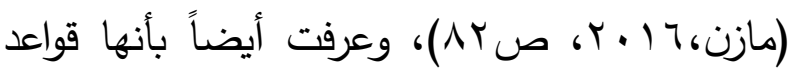

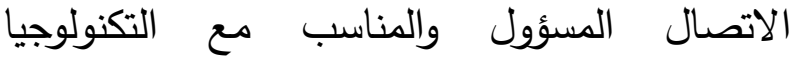
Wang \& ( ) (\&reddy, 2016, p) Xing

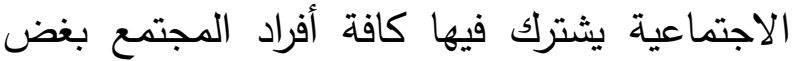
النظر عن الجنس أو العرق أو الدين أو أسلوب الحياة وتنطوي على عدد من الحقوق والواجبات. ويضيف حسان (ع (ب) أنها تسهم تزويد الطالب بترسانة من المهارات في مجال استخدامات تويتر والتدوين الإكتروني والفيس بوك، إضافة إلى اكسابه القدرة على استخدام بعض المواقع الإلكترونية الثهيرة لغرض التعليم والدراسة، ومنهج المواطنة الرقمية يعلم

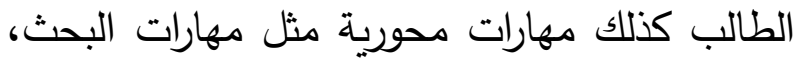

ملاحظته للانتشار الواسع، والاستخدام المفتوح لأدوات التكنولوجيا، فأضحى لكل فرد من أفراد المجتمع مجال

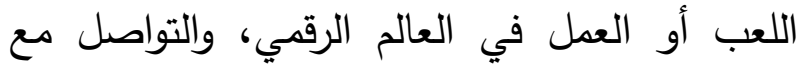
مجهولين رقميين قد يشكلون خطراً عليهم في أي الي الي مجتمع، وكذلك وجود رغبة جامحة لدى الأفراد (طلبة الددارس خاصة) بتصفح مواقع غير معروفة، وربما مشبوهة وخطيرة، فضلاً عن استحالة مراقبة كل ما يتم مشاهدته أو متابعته أو سماعه، و وتأسيساً على ذلك، كان لا بد من رسم سياسة توعوية تثثيفية لاستخدام

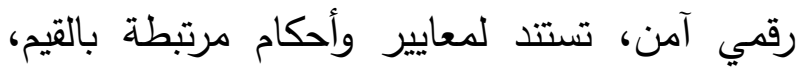
بقصد نثر ثنقافة المواطنة الرقمية في أماكن التعلم واللعب والتسوق تمهيداً لتهيئة الطلبة للاندماج في المجتمع الرقمي والمشاركة الإيجابية فيه. وحمايتهر

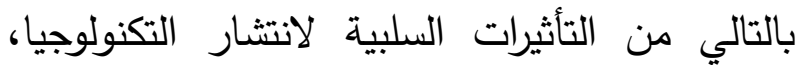
لاسيما مع انتثار استخدام أدواتها من قبل كافة الفئات لاتيات

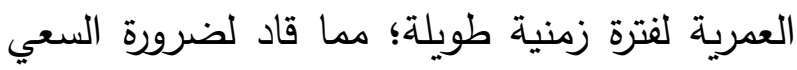
لحماية الطلبة من الحروب الرقمية، والجريمة الرقمية، ومن الأضرار الصحية والاجتماعية والاقتصادية العادية العادية والفكرية الناجمة عن الاستخدام غير السليم للتقنيات

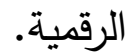
وكمبادرة من أجل معالجة هذا الواقع، جاءت إسهامات ريبل وبيلي وروس (Ribble, Bailey\& Ross)

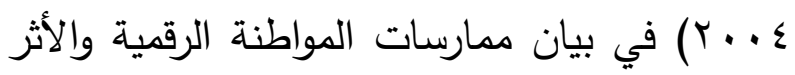
المنتظر من تطبيق هذا الففهوم على مجالات واسعة وتحديد الضوابط المحدة لهذه الاستخدامات 
الانترنت، والمفصولة زمنياً والمستقلة جغرافياً، متعددة الثقافات، والمجتمعات العالمية. كما تعد المواطنة الرقمية واحدة من غايات العملية التعليمية التي تعمل بجوهرها على تهيئة أفراد المجتمع

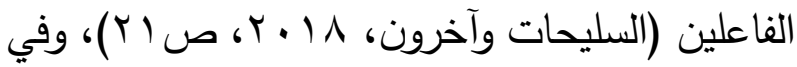
ذات السياق تشكل المواطنة الرقمية شكلاً من المشاركة الفعالة في المجتمع ولكن باستخدام الطرق

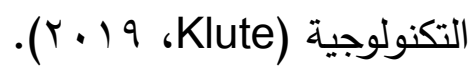

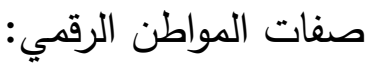
يطلق مصطلح المواطن الرقمي على المواطن الذي

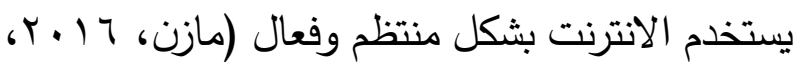

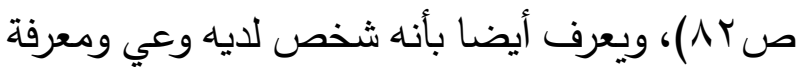

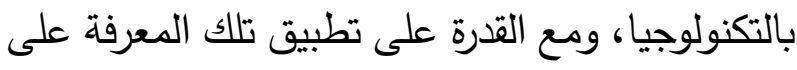

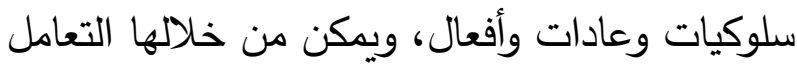
بشكل لائق مع التكنولوجيا نفسها أو مع الأشخاص

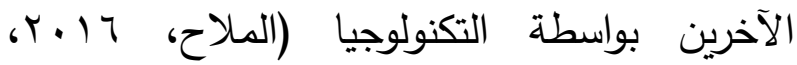

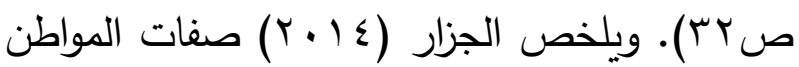

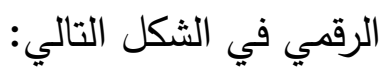

والتواصل، ومهارات حل المشكلات، إضافة إلى إثراء معرفته بثقافة بلاده وتاريخها، وتعزيز إيمانه بقيم الحرية والعدالة والديمقراطية، ويضيف المسلماني

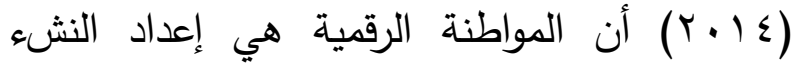
وتعليمه كيفية استخدام الوسائل التكنولوجية بالطرق السليمة المناسبة والأمنة التي تجلب له المنفعة، ومن خلال تدريب الطلبة على الالتزام بمعايير السلوك الإيجابي عند استخدام هذه الوسائل لأغراض التواصل

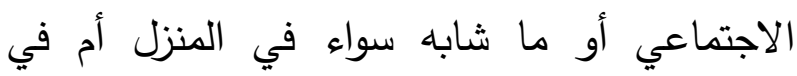
المؤسسة التعليمية والتربوية.

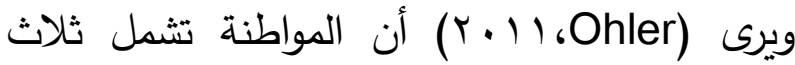
دلالات هي: أن المواطنة تحدث ضمن مجتمع معين،

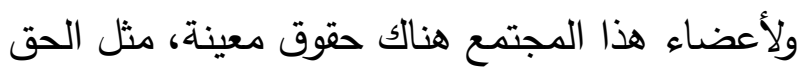

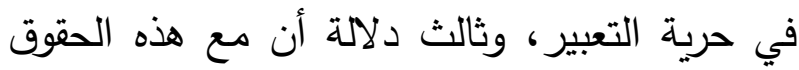
تأتي مسؤوليات وهي الحدود التي يجب أن يعيش بها أفراد المجتمع، وحيث أن المجتمعات تتألف من أفراد لذا يجب أن تكون الهيئات المكونة للمجتمع أعضاء مبتدئين لخلق مجتمع فعال، والمواطنة الرقمية تتطلب بالمثل المبادئ الأخلاقية للعمل بشكل فعال داخل

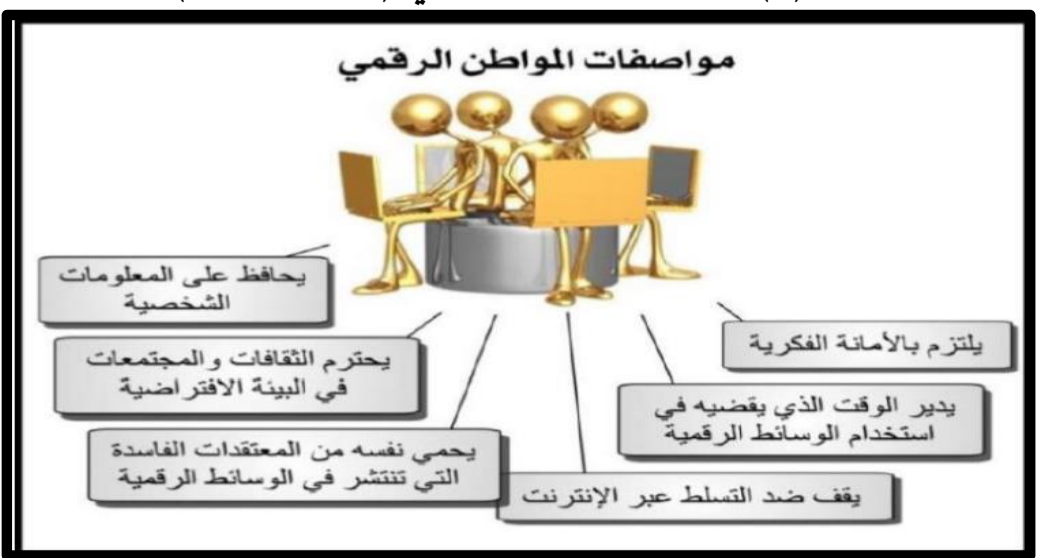


ع- ملم بالقراءة والكتابة ولغة الرموز والنصوص والتكنولوجيات الرقمية ويوظفها بكفاءة في الفضاء الإلكتروني.

0- على بينة بالتحديات في بيئات تكنولوجيا المعلومات ولاتصالات، ومتمكن من إدارتها بشكل بلاتل فعال. ؟- يستخدم تكنولوجيا المعلومات والاتصالات في التواصل مع الآخرين بطرق ذات معنى إيجابي.

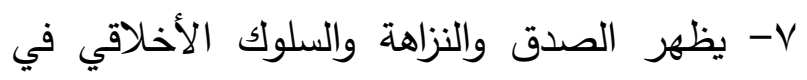
استخدام تكنولوجيا المعلومات والاتصالات.

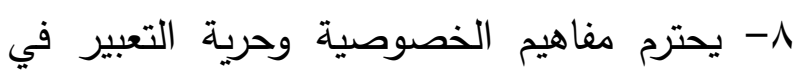

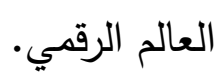
9- يساهم ويعزز بنشاط قيم المواطنة الرقمية. ( $(r)$ r NetSafe الأهداف التي يجب أن تحققها المواطنة الرقمية: ارتبطت المواطنة الرقمية بما يعرف بالحياة الرقمية والهدف الأساسي في التعليم للمواطنة الرقمية هو: تحسين التعلم والنتائج وإعداد الطلاب في إطار قواعد السلوك المناسب المسؤول لاستخدام التكنولوجيا ليصبحوا مواطنين القرن الحادي والعشرين، ويمكن

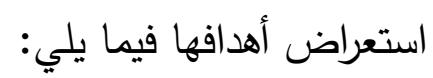
1- توعية مختلف المراحل العمرية بمفهوم المواطنة الرقمية بصورة محببة. r- برفع مستوى الأمان الإلكتروني. r- تمثيل البلاد بأحسن صورة من خلال السلوك الألمكرن

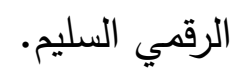

ويستنتج من الثكل السابق أن مواصفات المواطن الرقمي تتمثل في صفات الفرد الواعي الذي يلتزم

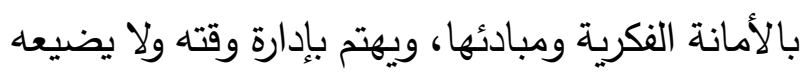
بلا فائدة تستدعي ذلك، وينظم وقته الذي يستخدم فيه

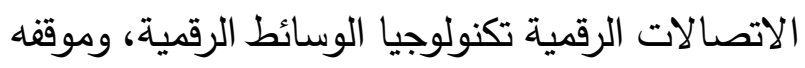

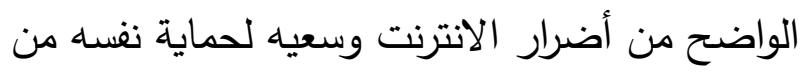
هذه المخاطر فيقف ضد تسلط الانترنت، ويحمي نفسه

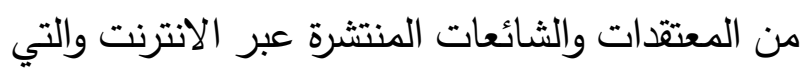

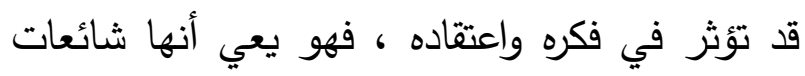
فاسدة ويستطيع التمييز بينها وبين الحقائق، وهو أيضا الثخص الذي يحتم الرأي الآخر ويترك مساحة

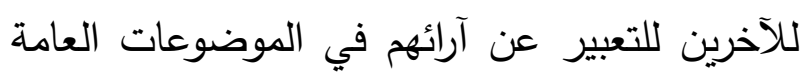

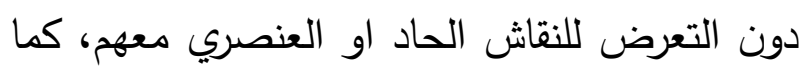
أنه يستطيع وسط كل هذه التحديات والمخاطر المحافظة على المعلومات الثخصية لحسابه الخاص دون تعرضها للسرقة أو الانتهاك. وينبغي أن يكون المواطن الرقمي متمكناً من مجموعة الرفات من المهارات ليستحق هذا اللقب؛ فيكون المواطن

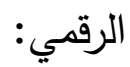
1- مستخدم واثق ومتمكن من تكنولوجيا الاتصالات والمعلومات. r- يستخدم التقنيات للمشاركة في الأنشطة التعليمية والثقافية والاقتصادية. r- يستخدم ويطور مهارات التفكير النقدي في ولهي الفضاء الإلكتروني. 
1- الوصول الرقمي: المشاركة الإكترونية الكاملة

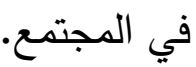
r- التجارة الإلكترونية: بيع وشراء البضائع إلكترونياً.

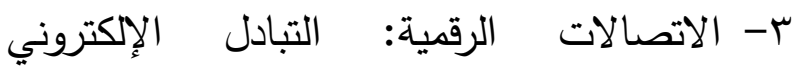

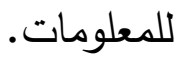

ع- محو الأمية الرقمية: عملية تعليم وتعلم التكنولوجيا واستخدام أدواتها. 0- اللياقة الرقمية: المعايير الرقمية لسلوك

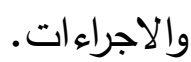

צ- القوانين الرقمية: المسؤولية الرقمية على الأعمال

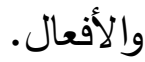
V - الحقوق والمسؤوليات الرقمية: الحريات التي يتمتع بها الجميع في العالم الرقمي. 1- الصحة والسلامة الرقمية: الصحة النفية والبعية البدنية في عالم التكنولوجيا الرقمية. 9- الأمن الرقمي (الحماية الذاتية): إجراءات ضمان

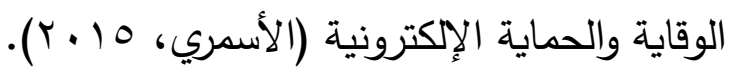
ويمكن شرح هذه المحاور الرئيسة في السياق المختصر التالي: - الوصول الرقمي: تمثل الفجوة الرقمية واحدة من أكثر القضايا الصعبة لوقية في مجتمع المعرفة، إذ توجد منافع اجتماعية

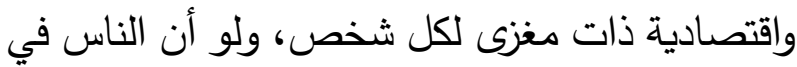

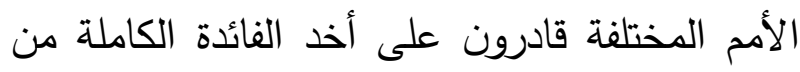

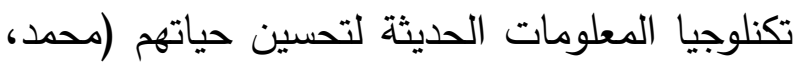
A ... r، (0)، لذلك فإن الوصول الرقمي حق إنساني
ع- تقليل الانعكاسات السلبية لاستخدام الانترنت على الحياة الواقعية. ه- نشر ثقافة حرية التعبير الملتزمة بالأدب. ז- تيسير وإيضاح الطرق المثلى لتعامل الفرد مع المواقف أو قضية إلكترونية معينة عبر إعداد مرجع متكامل للقضايا الإكترونية المنتشرة. - تحويل مفهوم الرقابة المشددة وانعدام الخصوصية - V إلى مفهوم الرقابة الذاتية وفق ضوابط شرعية الإسلامية والقيم الاجتماعية. 1- توفير بيئة تواصل اجتماعي خالية من العنف.

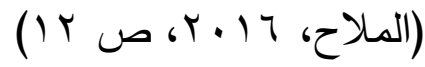

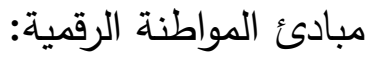
أبعاد المواطنة الرقمية عي عبارة عن المواطية الرحددات الثقافية والاجتماعية والصحية والقانونية والأمنية ذات الصلة بالتكنولوجيا، والتي تمكن الفرد من تحديد معايير استخدام التكنولوجيا بشكل مقبول وممارسة

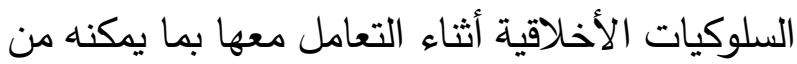
مسايرة العالم الرقمي وخدمة الوطن الذي يعيش فيه

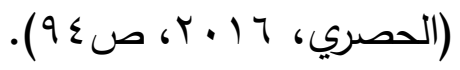
وفي هذا الإطار قد حددت منظمة ISTE (International Society For Technology in تسعة محاور عامة لتشكيل المواطنة

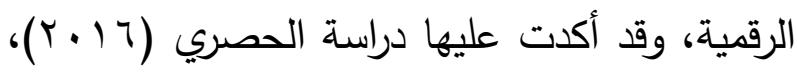

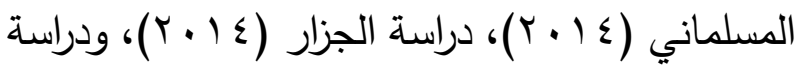

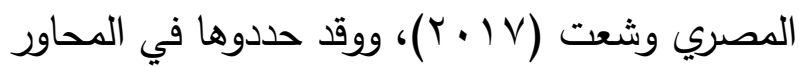
التسع التالية: 
لذلك بات من الضرورة أن يكتسب المواطن العصري أساليب وضوابط البيع والثراء في عالم الاقتصاد

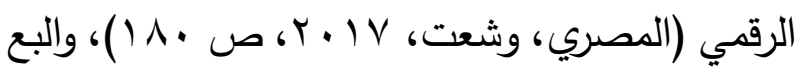
والثراء عبر شبكة الانترنت أصبح واقع في تزايد مستمر ، ومن ثم لابد من تحقيق الوعي بالضوابط الضئ

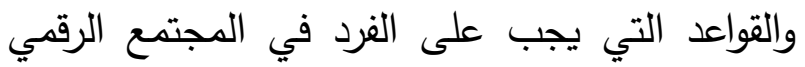
الالتزام بها حتى يصبح مواطن صالح ( الحصري، T ( • Y، ص ( • ())، والمواطنة الرقمية تثقف الفرد

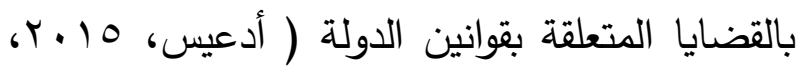
ص ( )، ومن هنا يستتتج الباحث مما سبق أن التجارة

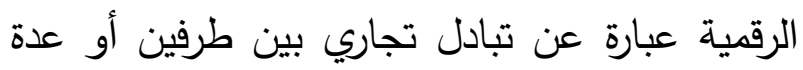

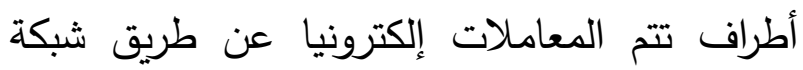
الانترنت، ونظرا لتوسع هذه الدائرة فإن من الضروري فري وضع مجموعة من الضوابط لتحكم هذه العمليات

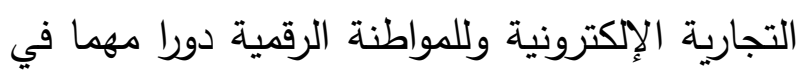
ذلك.

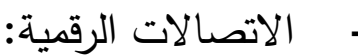

ويقصد بها التشارك الإككتروني للمعلومات وفهم طرق لاته الاتصال الرقمي ومساعدة الأفراد على معرفة قنوات الاتصال الرقمية الفاعلة وهذا يتطلب توعية الأفراد

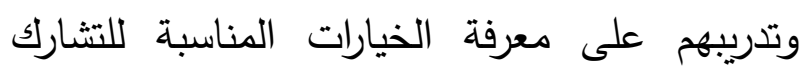

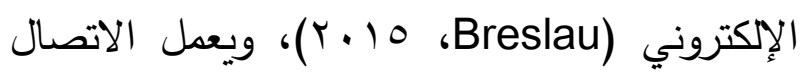
عبر الانترنت على توسيع شبكة علاقات الفرد الاجتماعية مع الآخرين على المستوى المحلي تلئي والإقليمي والدولي، وبصرف النظر عن خلفياتهر السياسية، والاقتصادية، والاجتماعية، والعرقية،
كفلته العديد من الدول لمواطنيها، والمواطنة الرقمية تهدف إلى ترسيخ مبدأ الوصول الرقمي واسع النطاق

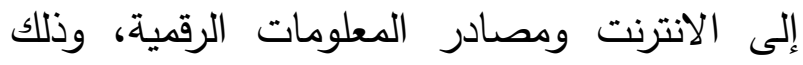

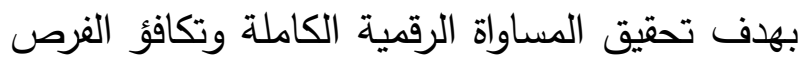
أمام جميع أفراد المجتمع بلا استثناء فيما يتعلق لماف لرفيه

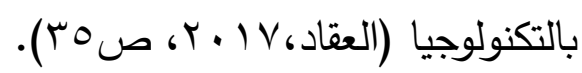

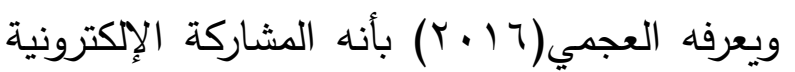
في المجتمع وإتاحة الفرصة للجميع في استخدام التقنية وتقديم التسهيلات لذوي الظروف الاقتصادية ولذوي الاحتياجات الخاصة وتوفير معامل للحاسب الآلي في المدرس وتثجيع المعلمين على استخدامها، فالمواطنة الرقمية تنطلق من ضرورة تحقيق مبدأ المشاركة الرقمية المتكافلة أو حق الوصول الرقمي لجميع أفراد المجتمع، دون تمييز وذلك لضمان تمتع جميع

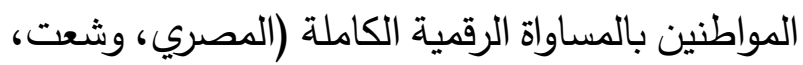

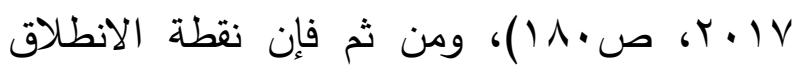
للمواطنة الرقمية في العمل على توفير الحقوق الرقمية

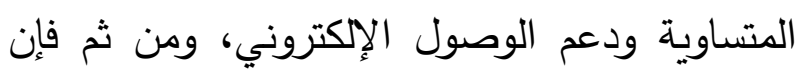
الإقصاء الإلكتروني يجعل من العسير تحقيق النمو لإنوان

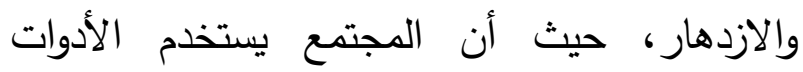

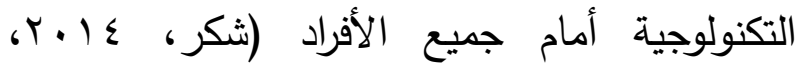

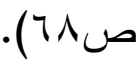

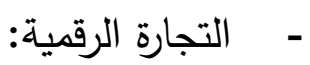
يطلق على عمليات تبادل السلع والخدمات والمعلومات في الاقتصاد الرقمي بالتجارة الرقمية التي تعتمد على بلى توظيف التكنولوجيا الرقمية في العمليات التجارية، 
المتاحة وزيادة وعيهم بطرق استخدامها والاستفادة منها

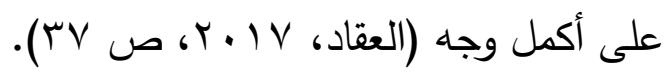

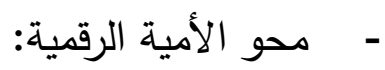

لم يعد مفهوم الأمية في هذا العصر مقتصراً على القراءة والكتابة فقط، بل تعدى ذلك إلى البعد الرقمي، وأصبح محو الأمية الرقمية هدفا للدول التي تسعى إلى بناء مجتمعات معرفة حديثة ومتطورة عن طريق اكساب شعوبها المهارات الأساسية التي تمكنهم من استخدام واستعمال تقنيات الحاسوب في حياتهم اليومية

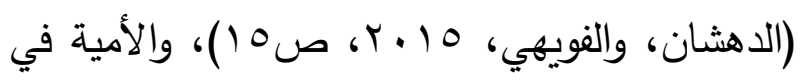
العصر الحالي لم تعد تقتصر على عدم القدرة على القراءة والكتابة، فقد تغير المفهوم وأضيف إليه بعد جديد وهو البعد الرقمي وأصبحت الأمية الحقيقية هي الأمية الرقمية، والمقصود بها عدم القدرة على استخدام التكنولوجيا الرقمية، وأن المواطنة الرقمية تسعى لمحو الأمية الرقمية من خلال تأهيل المواطنين وإيصالهم إلى مستوى ثقافي يمكنهم من استخدام التكنولوجيا

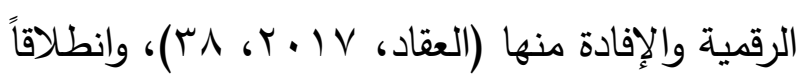
من كون المواطنة الرقمية هي ثقافة وقيم وسلوك، ومحو الأمية الرقمية تعني وصول المواطنين إلى مستوى تعليمي وثقافي يمكنهم من استخدام التكنولوجيا الرقمية والإفادة منها وتوظيفها في خدمة أنفسهم

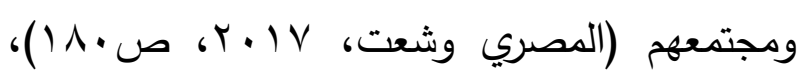
فالمواطنة الرقمية تقوم على تعليم وتتقيف الأفراد بأسلوب جديد أخذا في الاعتبار حاجة هؤلاء الأفراد إلى مستوى عالي من مهارات محو الأمية المعلوماتية
والجنسية، وقد أصبحت تقنيات الاتصال ونقل الدعلومات رافاًاً أساسيا، وركناً مهماً في بناء منظومة الآهاء

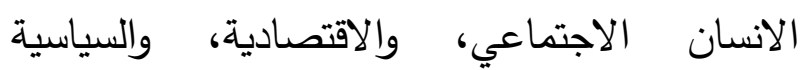

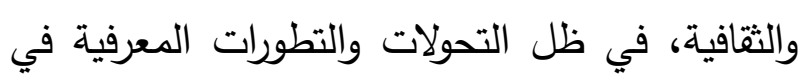

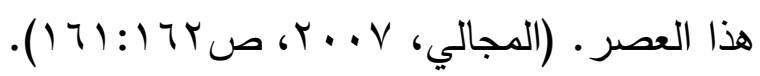
فالاتصال الرقمي هو تبادل المعلومات الإكترونية عن طريق التواصل والمشاركة باستخدام الأجهزة

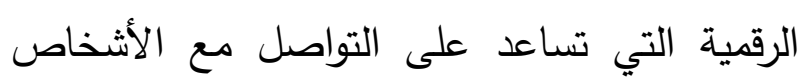
والمنظمات، والتعارف عن بعد، وممارسة الخدمات الثبكية بكل سرور وسهولة، وهي كثيرة كالبريد الإلكتروني، وبرامج التواصل الاجتماعي ومحركات

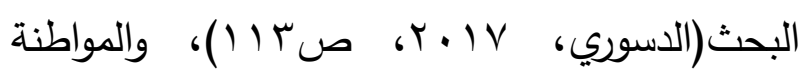
الرقية تهتم بأن يمتلك الفرد القدرة على اتخاذ القرار السليم أمام العديد من خيارات الاتصالات الرقمية المتاحة وأن يكون على وعي بكيفية استخدامها

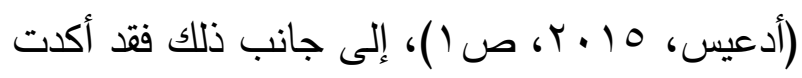
الدراسات على أن المواطنة الرقية يمكن أن تساعد الريات على تعزيز التواصل الايجابي بين أطراف العملية التعليمية (Dotterer, et. al. والاتصالات الرقمية هي اتصالات تتعامل بمدأ النظام

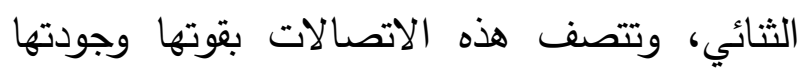
العالية مقارنة بالاتصالات التناظرية، والاتصالات الرقمية نوعين اتصال هما المتزامن وغير المتزامن، والمواطنة الرقمية تهدف إلى زيادة قدرة الأفراد على الكى الكين اتخاذ القرار السليم أمام خيارات الاتصالات الرقية الإدية 
المواطن بواجبه الرقمي على الوجه الصحيح يحتاج إلى تعلم معايير السلوك الرقمي المقبول في العالم

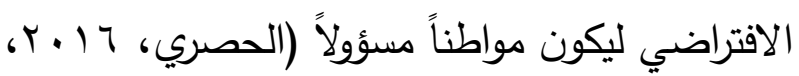

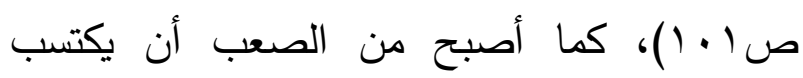
الطلاب قواعد اللياقة الرقمية قبل استخدامها، وعلى ملى الهي المؤسسة التربوية غرس الاستخدامات والتصرفات

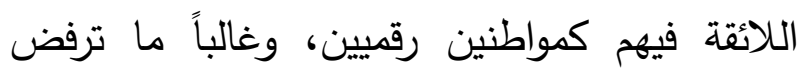

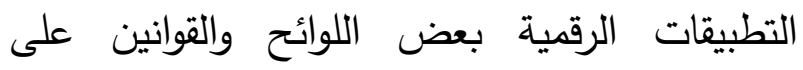
المستخدمين، أو يتم حظر التقنية بكل بساطة لوقف

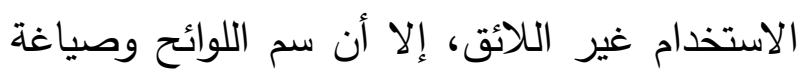

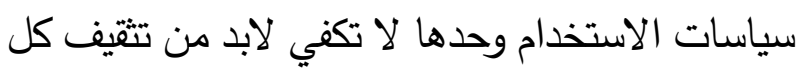
مستخدم وتدريبه على أن يكون مواطناً رقميا مسؤولاً

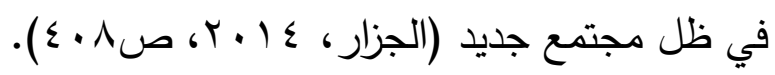
-

ويقصد بها القيود التشريعية التي تحكم استخدام التقنية

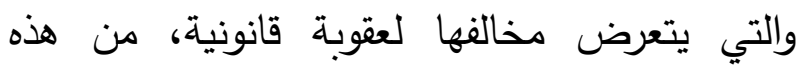
المخالفات نشر المواد المخالفة، السرقة العلمية مما لماله يجب توعية المستخدمين لهذه القوانين لحمايتهح

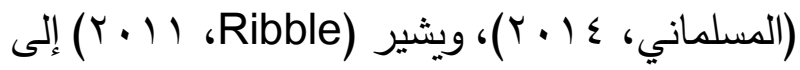
أن القوانين التي ترتبط بالتكنولوجيا يجب أن كون من

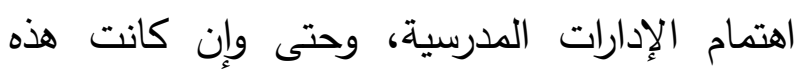
الانتهاكات تحدث بعيداً عن المدرسة، إلا أن آثرها

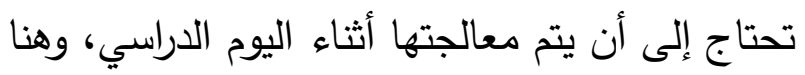

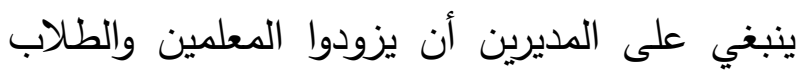

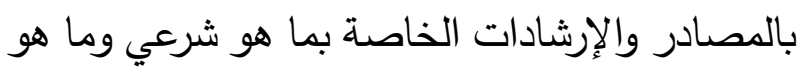
غير شرعي، ويشتق القانون الرقمي ببعض الدول من لإن
(شكر ، ؟ ( ـ Y، ص997)، والأمية الرقمية هي عبارة

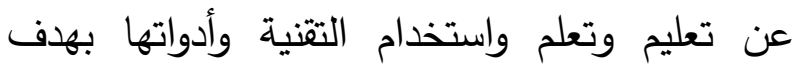
الاستفادة منها بشكل مناسب والتحقق من دقة وصحة المعلومات في شبكة الانترنت وتوفير محتوى رقمي ذو صلة بمجالات التعليم المتتوعة (العجمي،

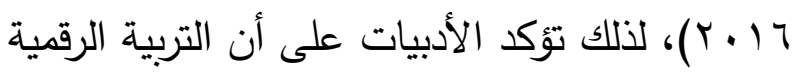
أصبحت ضرورة من ضرورات العصر، لدورها المحوري في تعريف الطلاب بالأدوات الرقمية، وكيفيو استخدامها بصورة مناسبة، حيث تعني التربية الرقمية بتتمية قدرات الطلاب على استخدام التكنولوجيا الرقمية، ومعرفة متى وكيف يمكن استخدامها

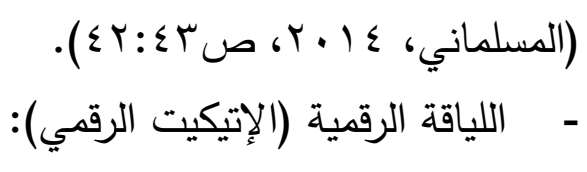
تعرف بأنها المعايير الرقمية للسلوك والإجراءات وتتعلق بالإشكاليات المرتبطة بالمواطنة الرقمية مثل السلوك غير المسؤول عند استخدام التقنية ولذلك يتم فرض قوانين ولوائح على مستخدمي التقنية فيجب تثقيف كل مستخدم للتقنية ليكون مواطناً رقمياً صالحاً

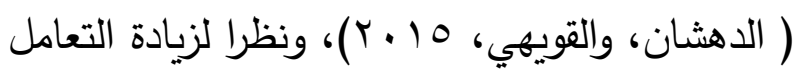
مع التكنولوجيا في جميع مجالات الحياة فقد ظهرت الحاجة إلى تعليم اللياقة والسلوك الرقمي وأن يكون جزء لا يتجزأ من العملية التعليمية في مختلف المراحل

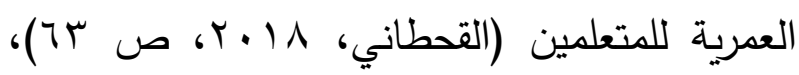
وتؤكد الدراسات على أنه ينتشر داخل العالم الرقمي

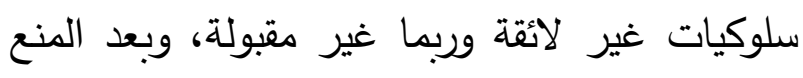
والحرمان للمواطن الرقمية للجميع ومن ثم حتى يقوم 


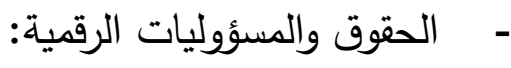
هي عبارة عن وعي الفرد بما يمتلكه من حقوق وما

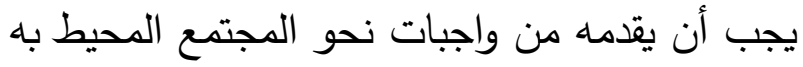
أثناء الاتصال الرقمي بالعلم المحيط به، واستخدامه

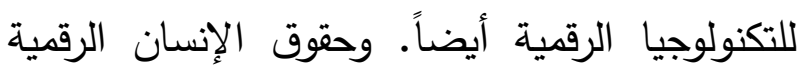
يقصد بها إجمال الحقوق التي تضمن للإنسان القدرة على تداول المعلومات والبيانات في البيئة التي يعيش لهي فيها، والحق في الوصول إليها واستخدامها، والقدرة

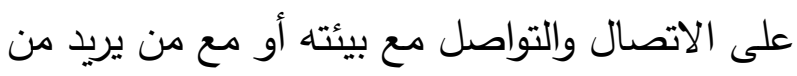

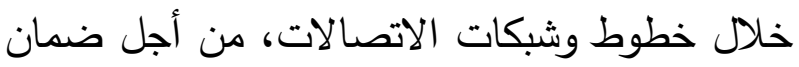
توفير آليات وتقنيات الوصول الرقمي إلى الجميع بلا

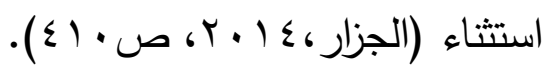

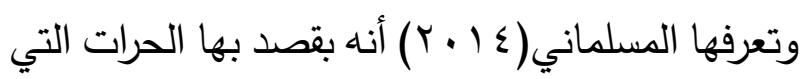
يتمتع بها الجميع في العالم الرقمي، ويتمتع المواطن الرقمي بمجموعة من الحقوق مثل الخصوصية وحرية التعبير التي من الضروري أن يفهمها ويعيها، مقابل

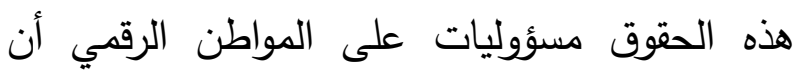
يحافظ عليها كي يكون مواطناُ رقمياً صالحاً.

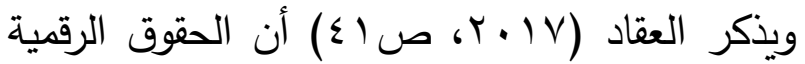
تشير إلى حقوق المواطن بالوصول إلى المحتوى الرقمي واستخدامه وإنشائه ونشره أو الوصل إلى أجهزة الرقمية أو شبكات الاتصال واستخدامها، ويتعلق هذا المصطلح بثكل خاص بحمايه وإعمال الحقوق وله الموجودة، مثل الحق في الخصوصية والسرية وحرية التعبير في سياق التتنيات الرقمية، وخصوصاً شبكة

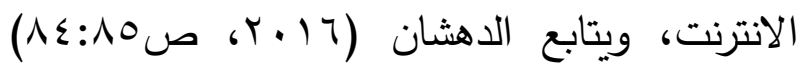

القانون الحالي كما هو الحال في كندا؛ حيث يحترم حقوق الملكية، ويجرم سرقة الهويات، وسرقة البرمجيات، وقرصنة الكمبيوتر، ونشر الفيروسات، وفي الولايات المتحدة أكد القانون على ضرورة إنشاء مواقع لمشاركة المواد المختلفة، وتدعيم تكنولوجيا إدارة Alberta Education, 2012, p ) الحقوق الرقمية (Ribble, 2011, P،28) ( أنه في ظل الثورة الرقمية التي (Y. V V) تجتاح العلم في العصر الحالي بات من الضرورة سن قوانين تحكم استخدام التكنولوجيا الرقية وذلك لحماية حقوق المستخدمين، وأن تكون صادرة عن جهات حكومية رسمية لضمان الالتزام بها، ويعد احترام القوانين الرقمية هو العنصر المعني بالأخلاقيات

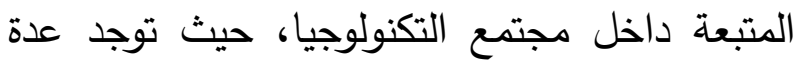
قوانين سنها المجتمع الرقمي لا بد من الانتباه إليها، ويقع تحت طائلة هذه القوانين كل من اخترق معلومات الآخرين، وقام بتنزيل الملفات الخاصة بهم بشكل غير

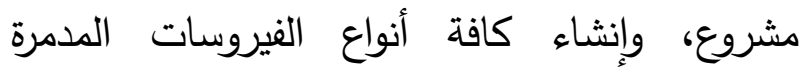
وفيروسات التجسس وغيرها من الرسائل غير المرغوب فيها أو سرقة هوية شخص آخر أو ممتلكاته، كل هذا لنا

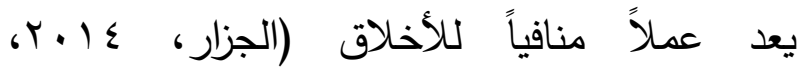
ص9 • ـ )، وبالتالي فالمواطنة الرقمية تتطلب الالتزام

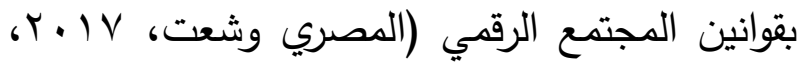
ص (1) (1). 
الفرد المتعامل مع التثنية لمشكلات صحية ونفسية لذا لابد من توعية المستخدمين لها للمحافظة على لهائ صحتهم (الدهشان، والفويهي، 0 ( • ب). فمما لاشك فيه أن التعامل غير الرشيد مع التكنولوجيا

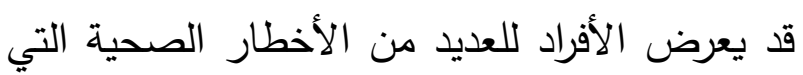
تؤثر عليهم، مثل الاجهاد البدني والنفسي والمشكلات الاجتماعية المترتبة على الاستخدام المفرط، ومن ثم ثلثي

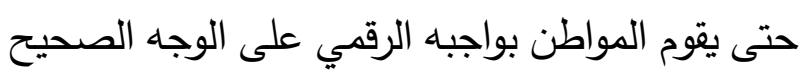

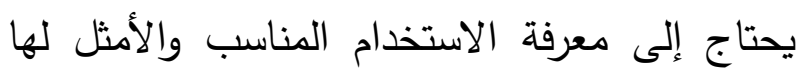

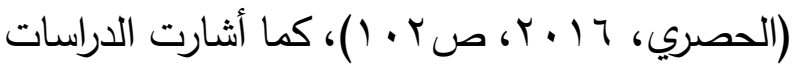
والأدبيات أن التعرض والتعامل مع التكنلوجيا الرقمية بشكل مبالغ فيه وقضاء وقت طويل في العالم الإككتروني الافتراضي يسبب أمراض عديده مثل وفئ

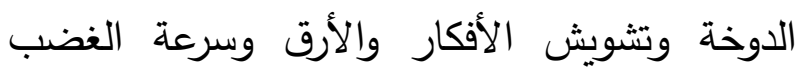

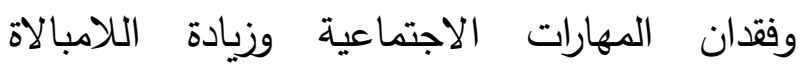
بالمستقبل.

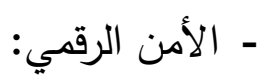
هو إجراءات ضمان الحماية والوقاية الرقمية، ويوجد الرقدية

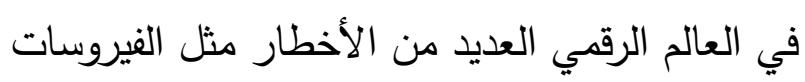

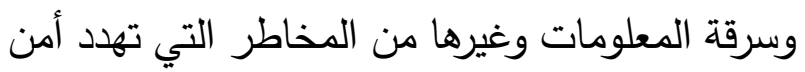
مستخدمي التقنية، ويحتاج المواطن الرقمي إلى معرفة وندي طرق الحماية من تلك المخاطر وكيف يتصدى لها مثل الاعتماد على برامج الحماية من الفيروسات

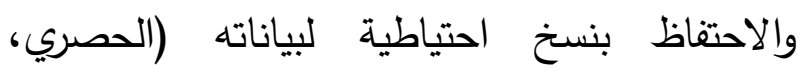

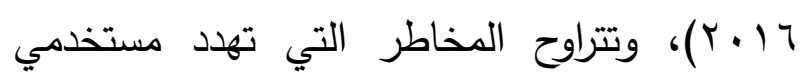
البيئات الرقمية بين الإصابة بالفيروسات المدمرة
مؤكداً على أنه لابد من دراسة ومناقشة الحقوق الرقمية

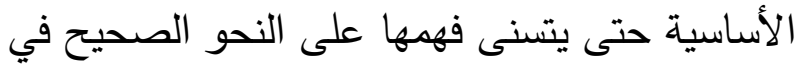

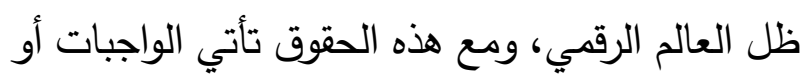
المسؤوليات، فلابد أن يتعاون المستخدمون على تحديد أسلوب استخدام التكنولوجيا على النحو اللائق، وبناء

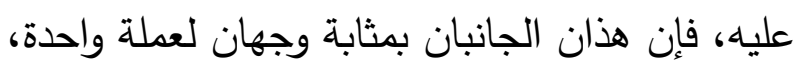
فلابد من تفعيلهما معاُ حتى يصبح كل مواطن رقمي

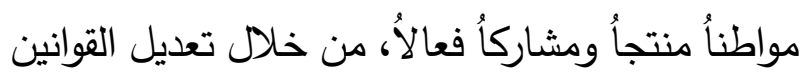

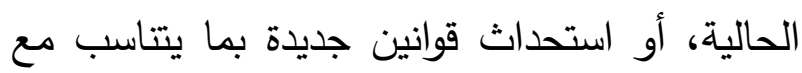
طبيعة الحياة في العصر الرقمي مع تثديد العقاب على من يخالفها لتكون مانعاُ من موانع ارتكابها. - الصحة والسلامة الرقمية:

فالمواطنة الرقمية تهتم بنشر الوعي الصحي الأمن

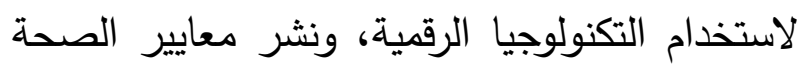

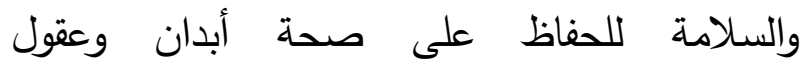

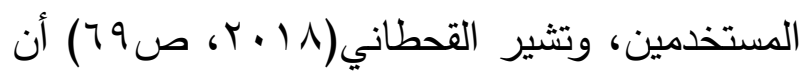
التكنولوجيا الرقمية أصبحت هي الرفيق الدائم لأغلب الأشخاص ولا عجب في ذلك فهي تحيط بنا من كل جانب ونكاد لا نستغنى عنها في جميع مناحي الحياة، لذا كان من الواجب تبنى عادات سليمة تضمن للفرد

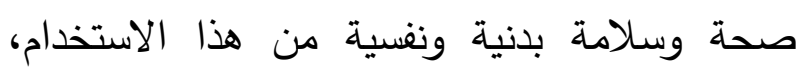
وتعرفها المسلماني(؟ ( ا ب) الصحة والسلامة الرقمية بأنها هي جميع الإشادات والاحتياطات اللزمة لضمان الصحة والسلامة البدنية والنفسية من جراء استخدام التقنيات الرقمية، ويقصد بها أيضاً الصحة ولنة الصناء

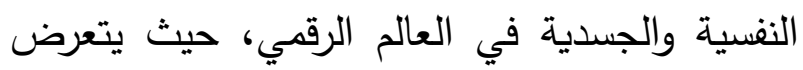


اشتدت الحاجة إلى التوعية بهذه القوانين وكذلك خلق

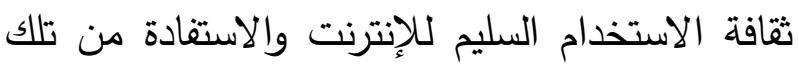

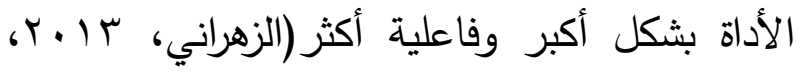
ص0:؛)، والأمن الرقمي يعني اتخاذ الاحتياطات

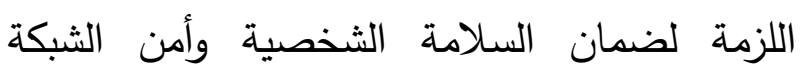

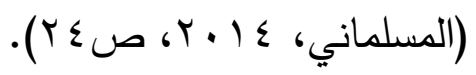

مراحل تتمية المواطنة الرقمية:

تحددت مراحل تتمية المواطنة الرقمية في المراحل

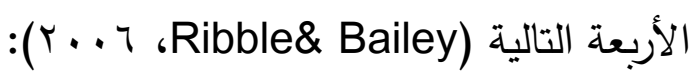

أولاً: مرحلة الوعي (Awareness) الوعي يعنى انهماك الطلاب في أن يكونوا مثنقين

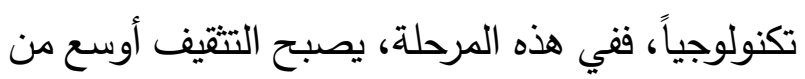

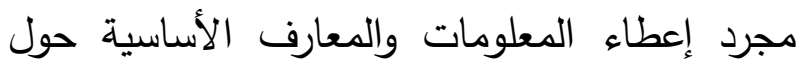
المكونات المادية والبرمجية، والتركيز على عرض التهاء أمثلة للاستخدام السيئ والغير المناسب لتلك المكونات

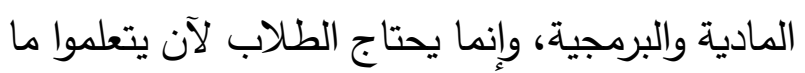
هو مناسب وغير مناسب عند استخدامهم لتلك التقنيات الرقمية الحديثة.

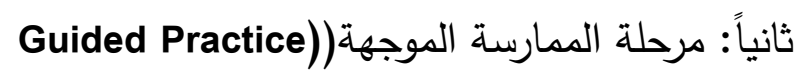
إن التلاميذ يجب أن يكونوا قادرين على استخدام

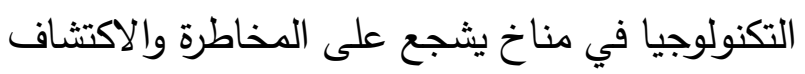
في مراحل متقدمة، وبدون الممارسة الموجهة فإنهم ربما لا يدركون هذه الطريقة المناسبة.

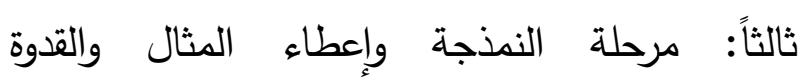
Modeling\& Demonstration))
والمعلومات المخزنة على الحاسوب، والاختراق للعبث بملفات المستخدم أو استغلال حاسوبه بقصد الإساءة إلى الآخرين، أو سرقة البيانات الثخصية بقصد الثصد الانتحال أو الابتزاز ، وسرقة بطاقات الأتمان، وأكثر

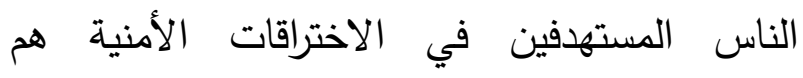
الأشخاص الذين يقومون بتصفح الانترنت ، حيث

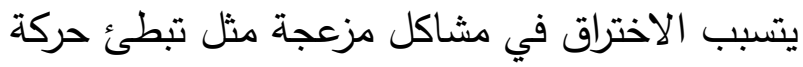
التصفح وانقطاعه على فترات منتظمة، ويمكن أن

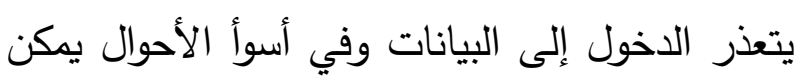
اختراق المعلومات الشخصية للمستخدم، وعلى الرغم

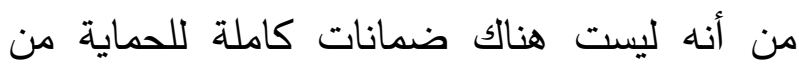

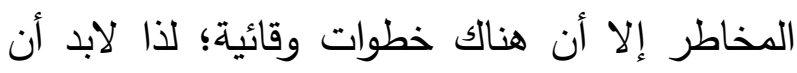
يكون المستخدمين بشكل عام على علم بما يتضمنه

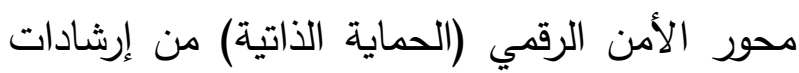
من شأنها أن تحميهح من مخاطر الإصابة بما يهدي

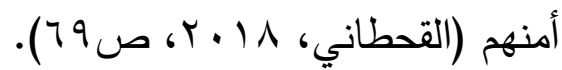
والجدير بالذكر أنه لا توجد معايير موحدة لقوانين

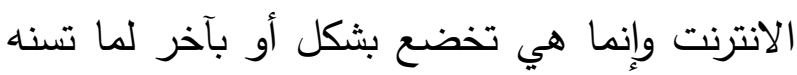
القوانين المحلية لذلك الإشكالية هنا عندما تكون المسألة القضائية" عابرة للدول " أي متعلقة بشخص لإند لهن أو شركة أو مقدم خدمة من دول مختلفة، لهذا قد عائل

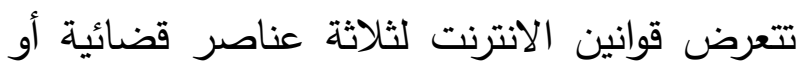
ثلاثة عوامل ألا وهي: أولاً: القوانين المحلية للمستخدم نفسه أو العميل، ثانياً: القوانين المحلية لمكان وجود الدانئ

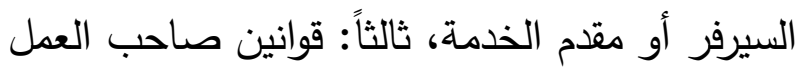
ومقدم السلعة، ومع انتشار الجرائم المعلوماتية مؤخراً 
وهذا يعنى إعطاء النموذج الواضح في الاستخدام أن تستخدم بها هذه التقنيات الرقمية الحديثة في الفصل

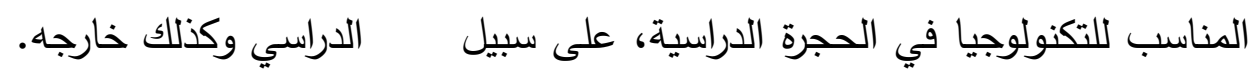

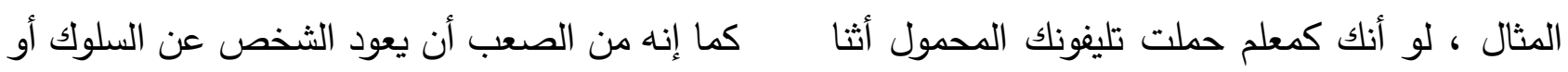
تواجدك بالفصل الدراسي ، فإنه ينبغي عليك إغلاقه الممارسة التي حدثت بالفعل ولكن يمكنه التفكير حلوها

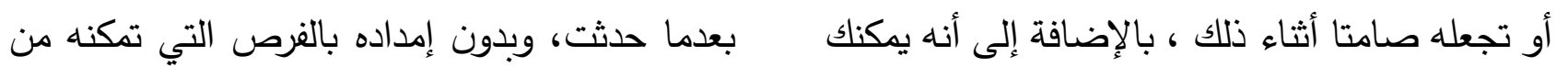

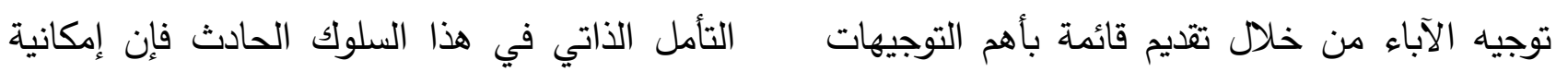
حول التساؤلات التي يمكن أن تطرح في أذهانهم في تكرار السلوك سوف تكون أكثر وأكثر في المستقبل

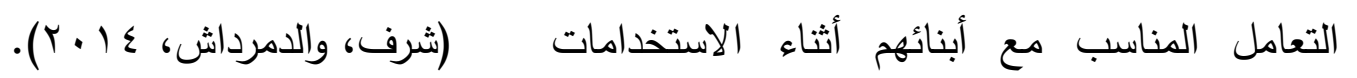

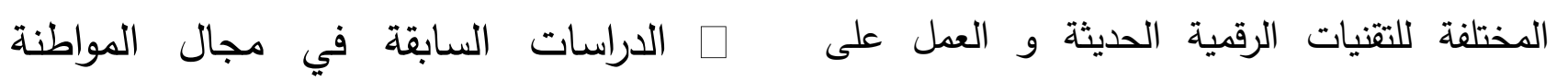
مناقشتها معهم ، فالكبار يحتاجون أن يكونوا نماذج الرقية الرقمية:

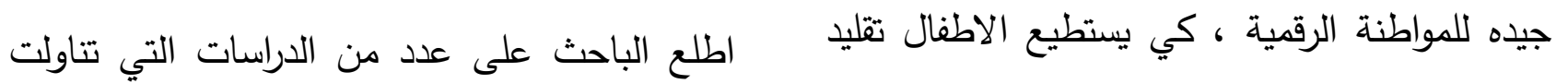

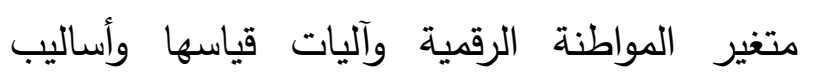
تتميتها، ثم قام بتلخيص أهم ما جاء فيها وجدولها

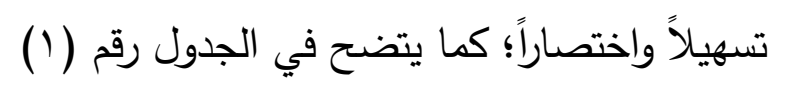

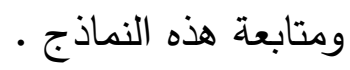
رابعاً: مرحلة التغذية الراجعة وتعديل النعاديل السلوك Feedback and Aalysis)) إن الفصل الدراسي ينبغي أن يكون المكان الذي يمكن

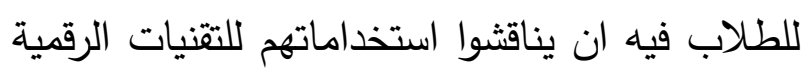
الحديثة ليروا كيف يمكنهم استخدامها بطريقة مناسبة. وأن ذلك يكون عن طريق إمداد الطلاب بالتكوين

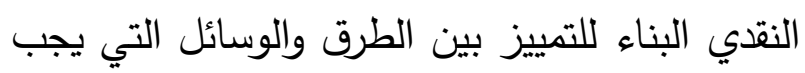


جدول (1) أهم الاراسات العربية والأجنبية التي تناولت المواطنة الرقمية

\begin{tabular}{|c|c|c|c|c|c|}
\hline أهم النتائج & منهجية البحث-مجتمع الدراسة-المتغيرات & الهذف الأساسي & عنوان البحث & 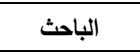 & ? \\
\hline 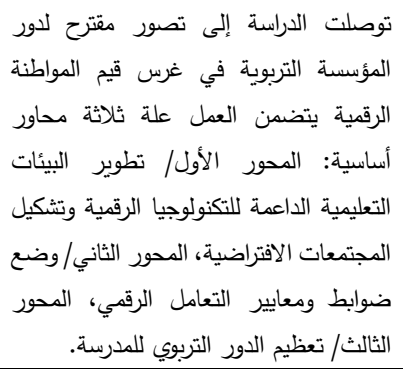 & 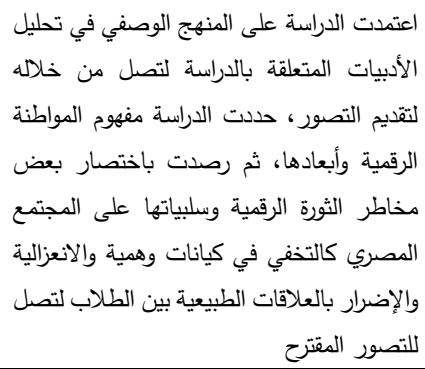 & 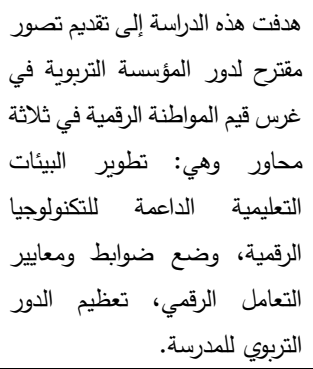 & في غرو المؤسسة التربوية & 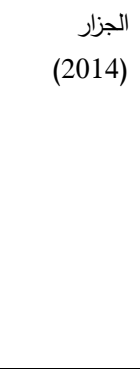 & 1 \\
\hline 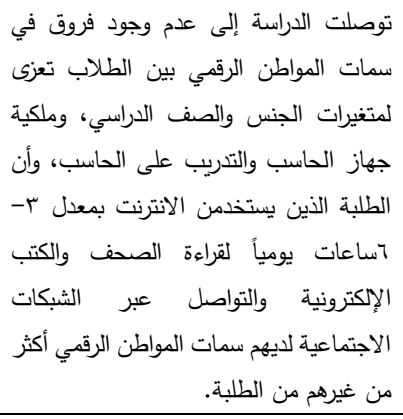 & 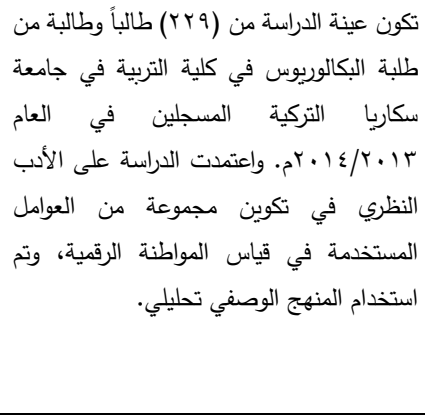 & 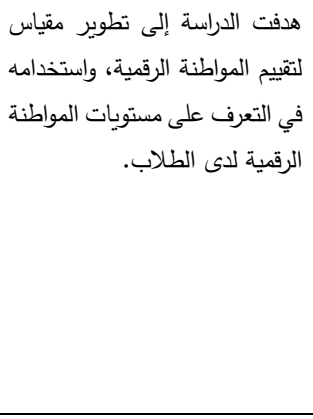 & Digital citizenship & $\begin{array}{r}\text { اسمان وكنان } \\
\text { Isman\& ) } \\
\text { CCanan } \\
(r .1 \varepsilon\end{array}$ & 2 \\
\hline 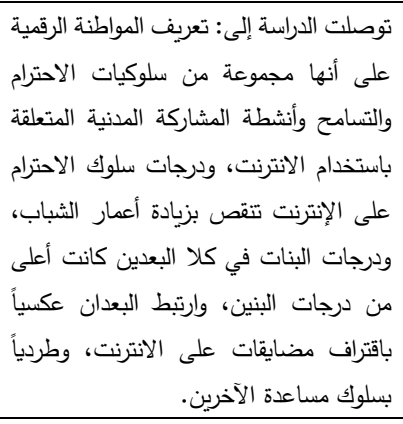 & 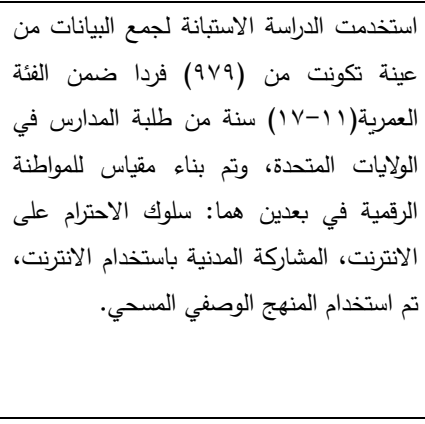 & 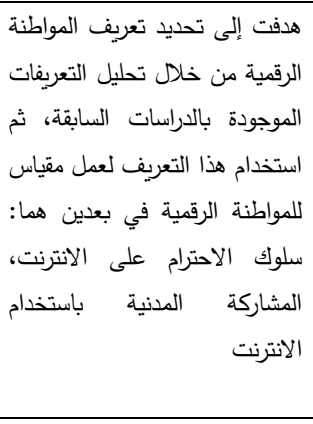 & تلعريف المواطنة الرقمية & $\begin{array}{r}\text { جونز وميتشل } \\
\text { Jones\& ) } \\
\text { ،Mitchell } \\
(r \cdot 10\end{array}$ & 3 \\
\hline 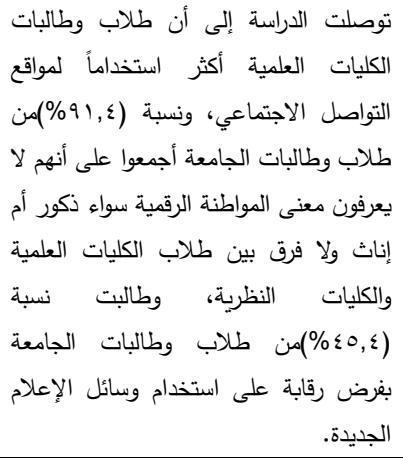 & 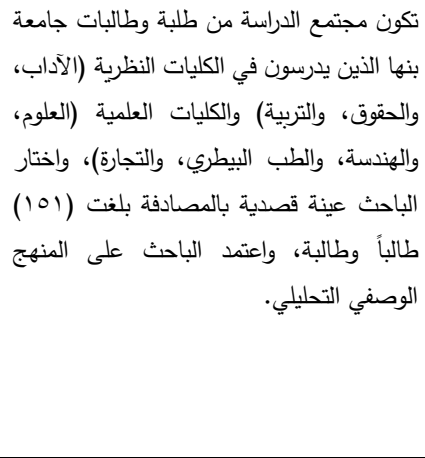 & 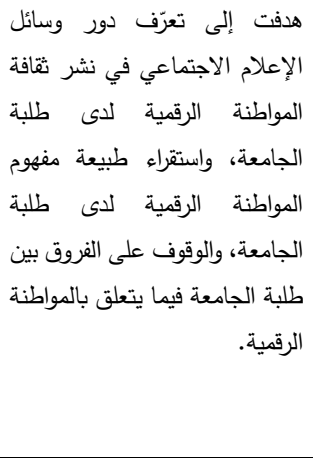 & الجديدة في دعم المواطنة & $\begin{array}{c}\text { السيد } \\
(r \cdot 17)\end{array}$ & 4 \\
\hline 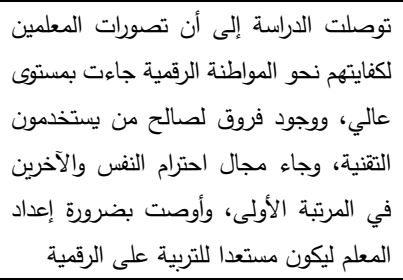 & فيناء استبانة طبقت على الباحث المنهج الوصفي والتحليلي، وقام من (؟ب) معلم & 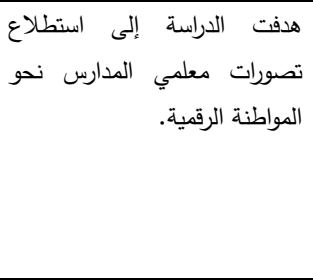 & 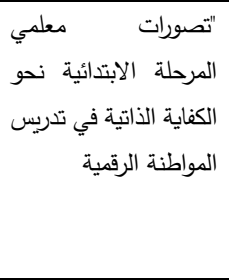 & 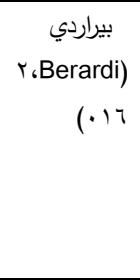 & 5 \\
\hline أظهرت نتائج الدراسة ت توافر قيم المواطنة & استخدم الباحث المنهج. الوصفي والمسحي & مدى توافر الدراسة إلى الكشف عن المواطنة لدى & مدى توافر قيم المواطنة & 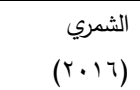 & 6 \\
\hline
\end{tabular}




\begin{tabular}{|c|c|c|c|c|c|}
\hline 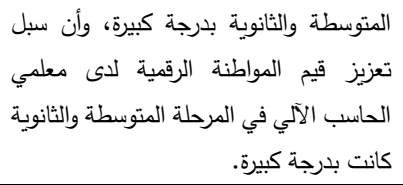 & 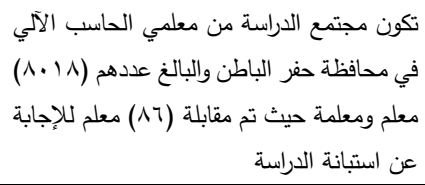 & المتوسطة والثانوية وسبل تعزيزها الآلي في المرحلة & المعاسب الآلي وتقنية في المافظة المرحلة & & \\
\hline 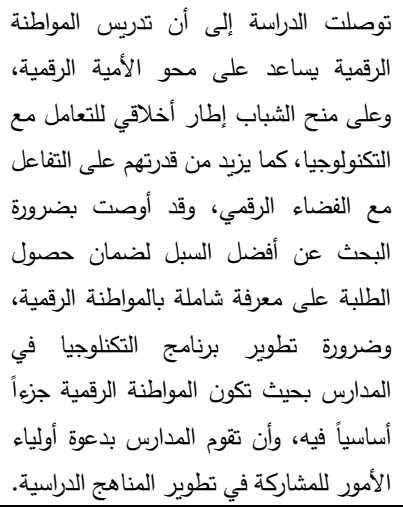 & 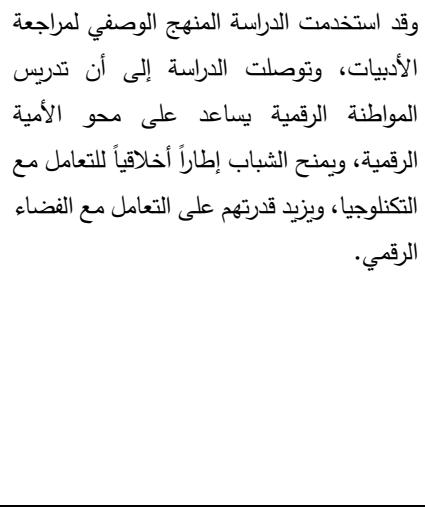 & 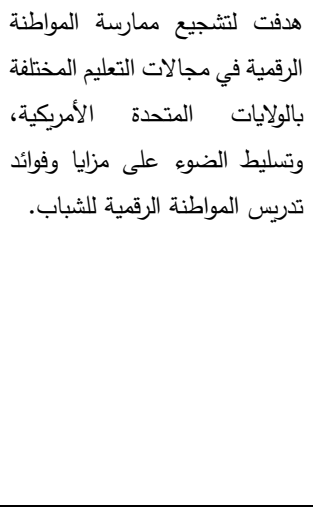 & تالفزيز الرقمية & $\begin{array}{r}\text { دويتيرر } \\
\text { وآخرون } \\
\text { Dottere ) } \\
\text { and et. } \\
\text { (r. . . al } 4 \text {. }\end{array}$ & 7 \\
\hline 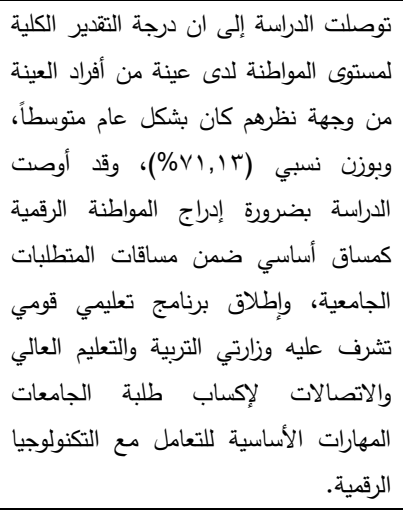 & 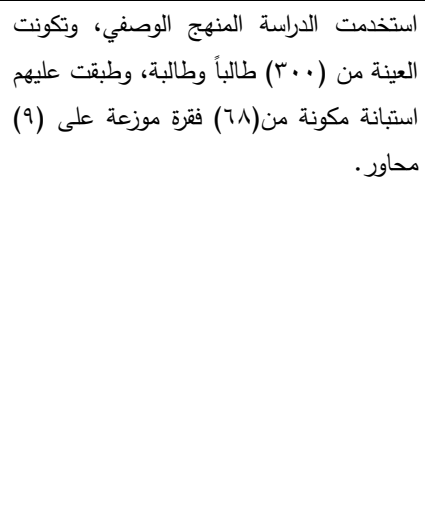 & تقدي & 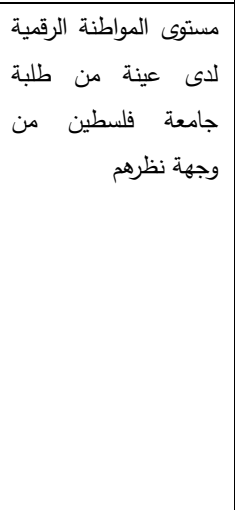 & 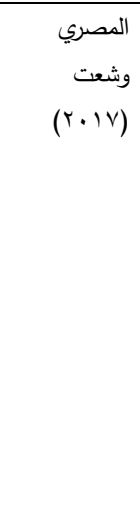 & 8 \\
\hline 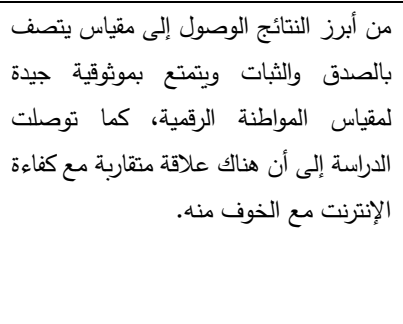 & 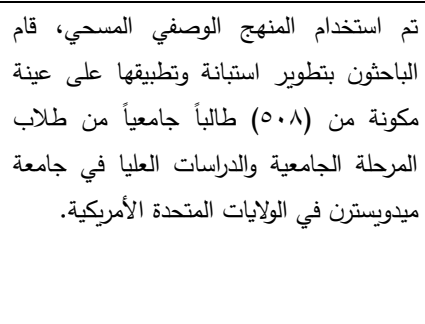 & 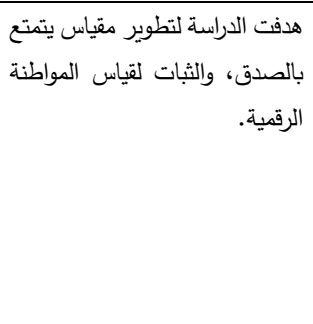 & $\begin{array}{l}\text { What it means to } \\
\text { be a citizen in the } \\
\text { internet age: } \\
\text { Development of a } \\
\text { reliable and valid } \\
\text { digital citizenship } \\
\text { scale }\end{array}$ & $\begin{array}{r}\text { شوي و وجلسمان } \\
\text { وكريستول } \\
\text { Glassma) } \\
\text { n\& Choi\& } \\
\text { CCristol } \\
\text { (r.lv }\end{array}$ & 9 \\
\hline والمي & 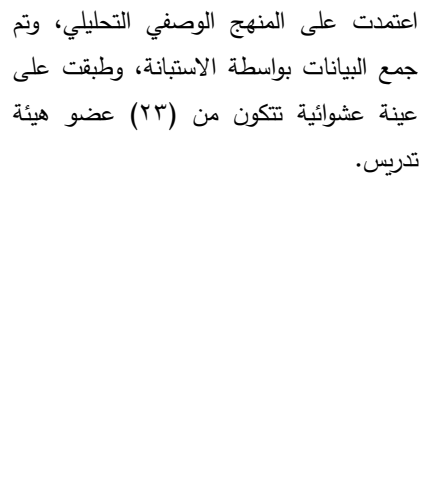 & 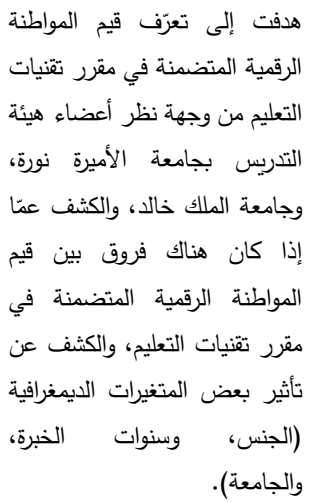 & 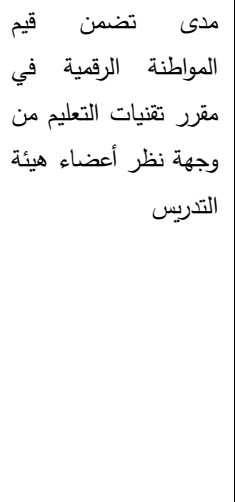 & $\begin{array}{l}\text { القحطاني } \\
(r \cdot 1 \Lambda)\end{array}$ & 10 \\
\hline
\end{tabular}




\begin{tabular}{|c|c|c|c|c|c|}
\hline 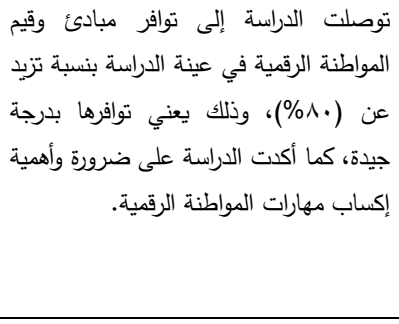 & 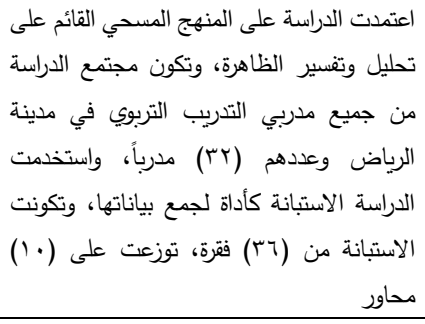 & التدوفت للتعرف على مدى توافر قيم الرقمية لدى مدربي & 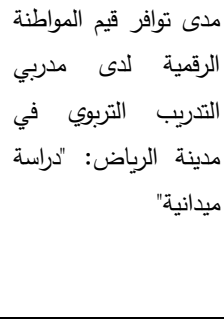 & آل & 11 \\
\hline 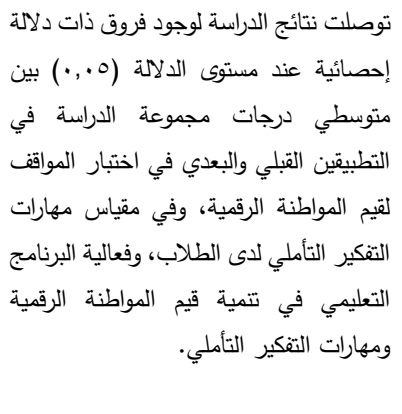 & 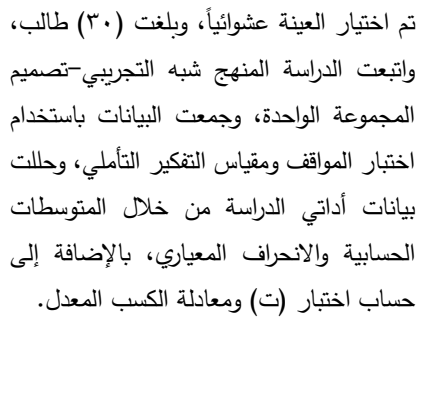 & 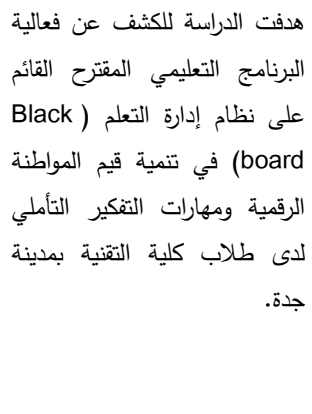 & 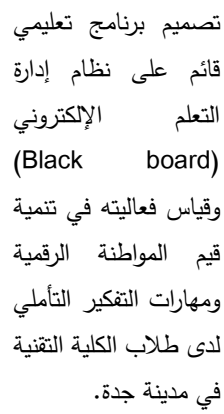 & $\begin{array}{l}\text { الحافظي } \\
\text { (r. (19) }\end{array}$ & 12 \\
\hline
\end{tabular}

قدمت رؤية وتصوراً مقترحاً حول غرس قيمة المواطنة

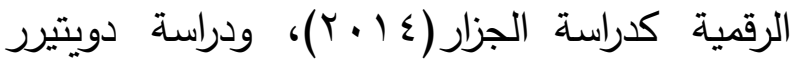

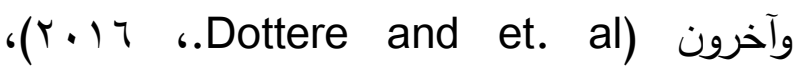
والدراسات التي عمدت لتطوير مقاييس لقياس مبادئ وقيم المواطنة الرقمية مثل دراسة شوي وجلسمان وكريستول Glassman\& Choi\& Cristol)

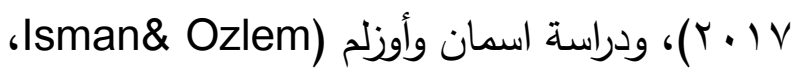

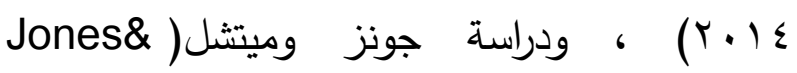
. $(r)$ ، Mitchell اتثقت الدراسة الحالية مع عدد من الدراسات السابقة في اختيار المنهج الوصفي كدراسة دراسة

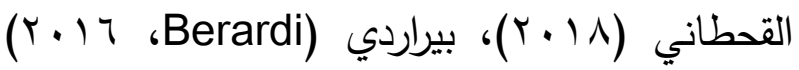

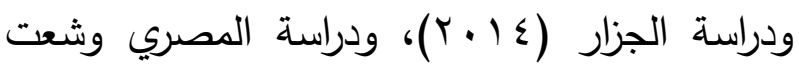

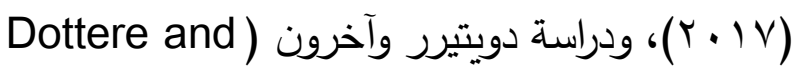
كا

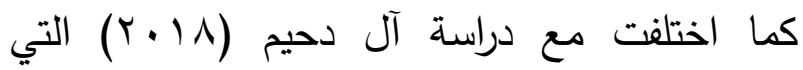

من خلال الاطلاع على الأدب النظري والدراسات السابقة المتعلقة بموضوع الدراسة الحالية؛ يمكن

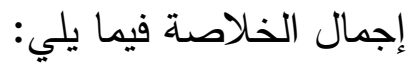
• استفادت الدراسة الحالية من الدراسات السابقة في الإطار النظري والمفاهيم المرتبطة بالمواطنة الرقمية.

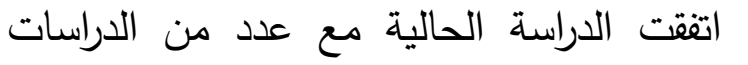
السابقة في أهمية مبادئ المواطنة الرقمية وجدارتها بالدراسة وحاجة طلاب الجامعة إلى معرفتها والوعي بقيمها التفصيلية. • استفادت الدراسة الحالية من الدراسات السابقة في المناهج البحثية، واستقرت إلى مناسبة المنهج الوصفي المعتمد على تحليل المحتوى لتحقيق أهدافها. هاستفادت الدراسة الحالية من عدد من الدراسات السابقة في بناء أداة الدراسة المتمثلة في بطاقة لتحليل محتوى الصفحات الرسمية للجامعات على شبكة الإنترنت، وبصفة خاصة من الدراسات السابقة التي 
التكنولوجيا ومتغير المواطنة الرقمية، وجعل هدف البحث قياس دور الجامعات السعودية في تتمية وتعزيز قيم المواطنة الرقمية سواءً في الأخبار التي لتي تتشرها الجامعة على صفحتها الرسمية، أو من خلال

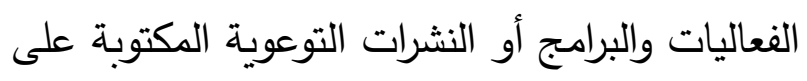
صفحات الويب الرسمية لهذه الجامعات، وبذلك يكون

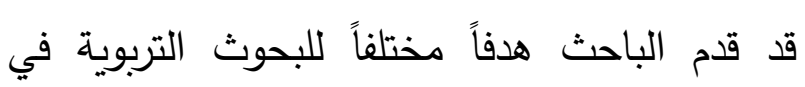
تكنولوجيا التعليم. منهج الدراسة وإجراءاتها: منهج الدراسة:

اعتمدت الدراسة الحالية على المنهج الوصفي التحليلي (تحليل المحتوى) لمناسبته لطبيعة الدراسة ومتغيراتها، حيث تم قياس درجة إسهام الجامعات السعودية في تعزيز قيم المواطنة الرقمية التسعة من خلال قائمة

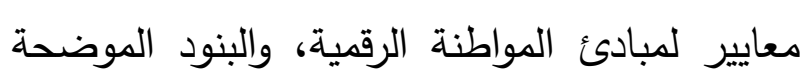

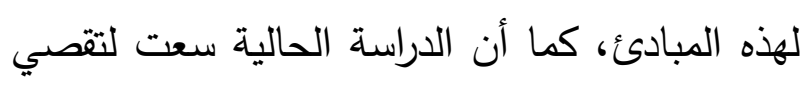
دور الجامعات في تتمية وتعزيز مبادئ المواطنة الرقمية وعلاقته بالعمر الزمني لهذه الجامعات.

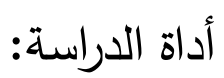
قام الباحث في هذه الدراسة بإعداد وبناء الأداة الخاصة

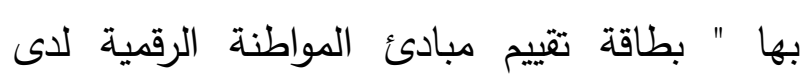

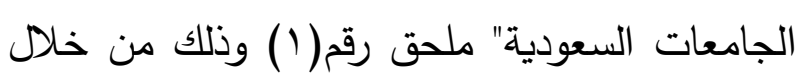
الاطلاع على الدراسات والأدبيات التي سبق وتحدثنا عنها بالتقصيل في محور المواطنة الرقمية في الفصل لإنل السابق للدراسات السابقة. وصف البطاقة:

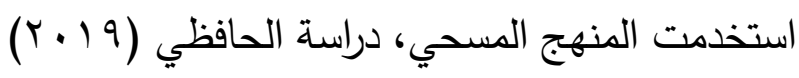
التي استخدمت المنهج شبه التجريبي.

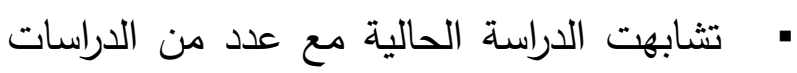
السابقة في محتويات أداة الدراسة حيث من الدراسات

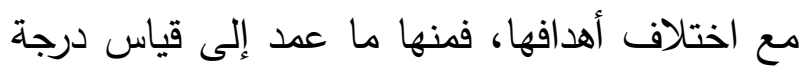
قيام المؤسسات بتعزيز المواطنة الرقمية لدى الملتحقين

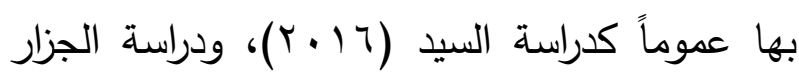

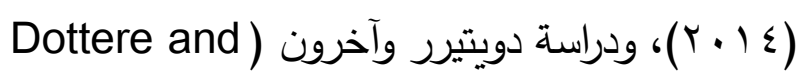

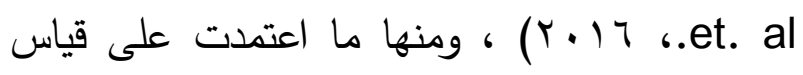
المواطنة الرقمية لدى فئات من الأفراد محددة منهم

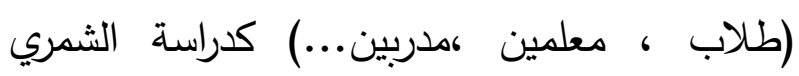

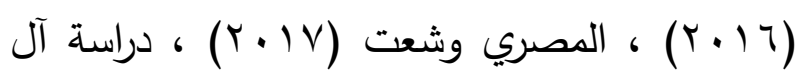

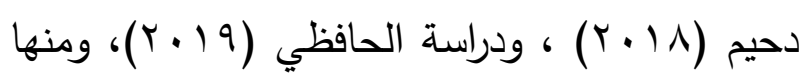
ما عني بدراسة توافر قيم المواطنة الرقمية في المقررات

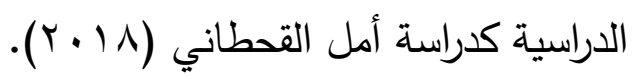

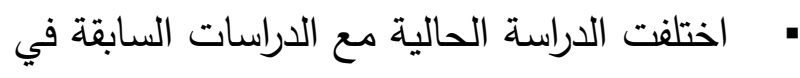

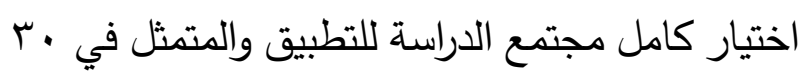
جامعة حكومية. اختلفت الدراسة الحالية مع الدراسات السابقة في استخدام تحليل المحتوى كأسلوب لدقته في جمع المعلومات، وموضوعية حيث لا يتأثر كالاستبانات والتجارب بالعنصر البشري واختلاف مزاجيته والعوامل النفسية المختلفة المتعلقة بالنفس البشرية.

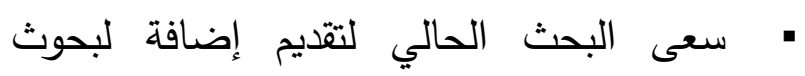
تكنولوجيا التعليم، مستخدماً متغير المواطنة الرقمية بشكل مختلف عن الدراسات السابقة؛ فقد مزج بين مئنيز 
• وضع التصور المبدئي للأداة وتضمن المحاور التسعة الرئيسية التي اتفقت عليها الدراسات السابقة، (T) بند فرعي من تصور الباحث وبنائه. عرض بطاقة التقييم والتي كانت بعنوان" بطاقة

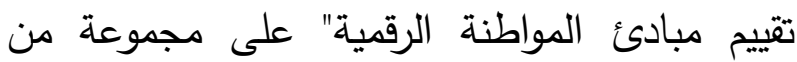
المحكمين للحكم على درجة صدق وملائمة فقرات

البطاقة وصحتها للتطبيق والتتييم باستخدامها. تطبيق مقترحات المحكمين والاستفادة منها في تقديم الصورة النهائية للبطاقة، والتي تمثلت في تعديلات بالحذف لبعض العناصر والاضافة الأخرى وتعديل الصياغة في بعضها، وبعد الانتهاء من هذه الخطوة تم تقديم البطاقة في صورتها النهائية كما يمثلها لهاهيا
اعتمد الباحث المبادئ الرئيسة للمواطنة الرقمية والتي

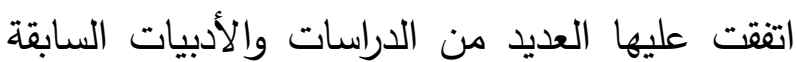

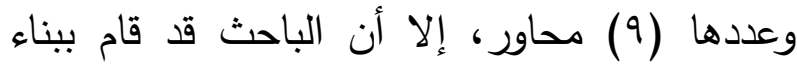
واستتتاج القيم الفرعية التي تضمنتها هذه المحاور الرئيسة وتوصل إلى (01) قيمة مندرجة تحت المبادئ الرئيسة التسعة للمواطنة الرقمية.

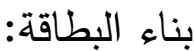
قام الباحث بعدة خطوات لتظهر الأداة بصورتها

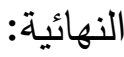
مراجعة البحوث والدراسات والأدبيات التي سبق وتتاولت محور المواطنة الرقمية وقياسها في عدة

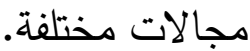

الجدول رقم (r): (r)

جدول (ץ) المحاور والبنود المكونة لبطاقة تقييم المواطنة الرقمية

\begin{tabular}{|c|c|c|}
\hline عدد البنود & المحاور الرئيسية للمواطنة الرقمية & م \\
\hline 7 & الوصول الرقمي & 1 \\
\hline 6 & التجارة الرقمية & 2 \\
\hline 8 & الاتصالات الرقمية & 3 \\
\hline 5 & محو الأمية الرقمية & 4 \\
\hline 6 & اللياقة الرقمية & 5 \\
\hline 7 & القوانين الرقمية & 6 \\
\hline 6 & الحقوق والمسئوليات الرقمية & 7 \\
\hline 7 & الصحة والسلامة الرقمية & 8 \\
\hline 6 & الأمن الرقمي & 9 \\
\hline 58 & 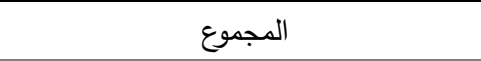 & \\
\hline
\end{tabular}

ومناسبة ووضوح فقرات البطاقة، وتراوحت نسبة الاتفاق على البطاقة ككل مابين • 9-91\% مما يشير

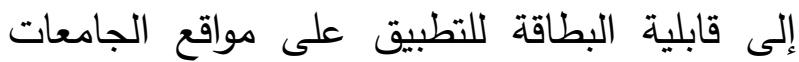
بدرجة ثقة عالية. ثانياً: صدق الاتساق الداخلي:
تقنين أداة الدراسة:

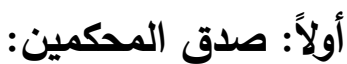
تحقق الباحث من صدق هذه البطاقة عن طريق عرضها على عدد من المحكمين المختصين في المناهج وتقنيات التعليم للحكم على مدى ملائمة 
الاتساق الداخلي لهذين المحورين بواسطة برنامج

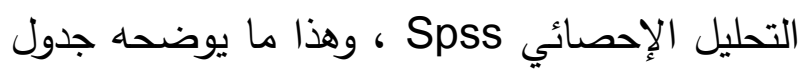

تم حساب معامل الاتساق الداخلي لمحاور الاستبانة

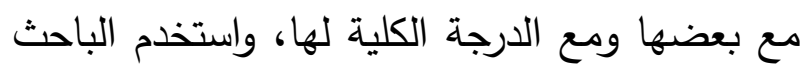

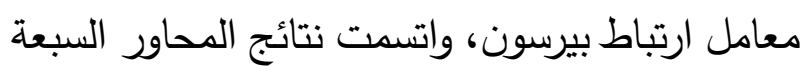
الاول بثبات جيد، بينما لم يكن هناك اتساق بين

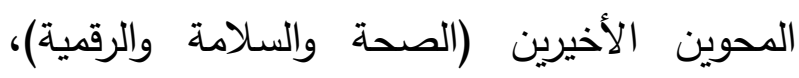
(الأمن الرقمي) والأداة عمواً ، ويعود السبب في ذلك الكين

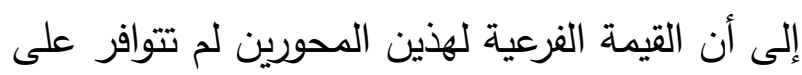

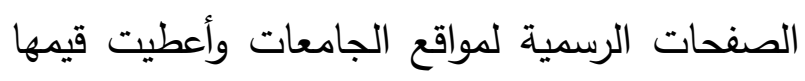
(صفر) في البطاقة مما أدى لتعذر حساب لجاب قيمة

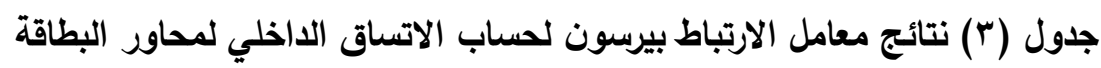

\begin{tabular}{|c|c|c|c|c|c|c|c|c|c|c|}
\hline الارتباط & |الرقمي & |الرقمة & والمسؤوليات & الرقوانية & الرقية اللياقة & | محو الأمية & الاتصالات & التجارة & الرقصي & المحور \\
\hline $0.378^{*}$ & & & & & & & & & 1 & الوصول الرقمي \\
\hline 0.269 & & & & & & & & 1 & $-0.263^{-}$ & التجارة الرقمية \\
\hline $0.904 * * *$ & & & & & & & 1 & 0.092 & $0.526 * *$ & الاتصالات الرقمية \\
\hline $0.663 * *$ & & & & & & 1 & $0.663 * *$ & $-0.104-$ & 0.470 *** & محو الأمية الرقمية \\
\hline $0.768 * *$ & & & & & 1 & $0.367 * *$ & $0.516 * *$ & 0.087 & 0.101 & اللياقة الرقمية \\
\hline $0.849 * *$ & & & & 1 & $0.499 * *$ & $0.485 * *$ & 0.776 ** & 0.329 & 0.122 & القوانين الرقمية \\
\hline 0.219 & & & 1 & 0.179 & $-0.146^{-}$ & $0.683^{* * *}$ & 0.304 & $-0.068-$ & 0.315 & الحقوق والمسؤوليات \\
\hline.$b$ & & 1 &.$b$ &.$b$ &.$b$ &.$b$ &.$b$ &.$b$ &.$b$ & الصحة والسلامة \\
\hline.$b$ & 1 & .b &.$b$ &.$b$ &.$b$ &.$b$ &.$b$ &.$b$ &.$b$ & الأمن الرقمي \\
\hline
\end{tabular}
* * تغني أن الأرقام دالة عند مستوى دلالة (1 .,.) ، * تعني أن الأرقام دالة عذ مستوى دلالة (ه .,.)

معامل(ألفا) كرونباخ لحساب التماسك الداخلي ثالثاً: ثبات الأداة: للبطاقة، كما يوضحها جدول (ء) التالي: تم حساب ثبات بطاقة تقييم مبادئ المواطنة الرقمية عن طريق استخدام برنامج (Spss)، واختيار 
جدول (؛ ) معامل ثبات بطاقة تقييم مبادئ المواطنة الرقمية

\begin{tabular}{c|c|c|c}
\hline معامل (ألفا) كرونباخ الثبات & معات \\
\hline
\end{tabular}

للدرجات المعطاة لفئات الإجابة وبطريقة رياضية على

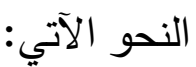
المدى = أكبر قيمة لفئات الإجابة - أصغر قيمة

$$
\begin{aligned}
& \text { لفئات الإجابة = r- }
\end{aligned}
$$

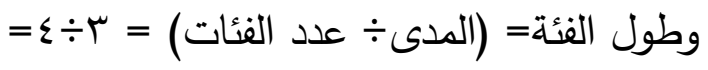

$$
\begin{aligned}
& \cdot, \text { Vo }
\end{aligned}
$$

وبذلك يكون معيار الحكم على قيمة المتوسط الحسابي

$$
\text { كما في الجدول التالي: }
$$

درجة تقييم مبادئ المواطنة الرقمية في الصفحات

الرسمية للجامعات موضع الدراسة تكون متوسطة

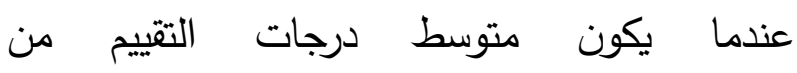

$$
\text { ( } 1,0 \text {, • • (إلى }
$$

درجة تقييم مبادئ المواطنة الرقمية في الصفحات

الرسمية للجامعات موضع الدراسة تكون منخفضة عندما يكون متوسط درجات التقييم من ( • إلى 0 >, • )

$$
\text { الإجابة عن أسئلة الدراسة: }
$$

السؤال البحثي الأول والذي ينص على:" ما درجة

$$
\text { تعزيز الجامعات السعودية لقيم الوصول الرقمي؟" لإول }
$$

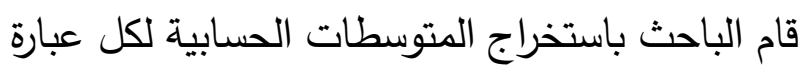
من عبارات المحور ، ثم المتوسط الكلي لهذا المحور باستخدام برنامج Spss للمعالجة الإحصائية وذلك

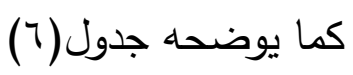

يتضح من جدول (§) إن معامل الثبات يساوي ال9, ،وهو معامل ثبات مرتفع يشير إلى صلاحية البطاقة للتطبيق.

$$
\text { نتائج الدراسة ومناقشتها: }
$$

\begin{tabular}{|c|c|}
\hline المتوسط الحسابي & معيار الاستجابة \\
\hline من هY,Y إلى ץ & عالية جداً \\
\hline من 0 , إلى & عالية \\
\hline 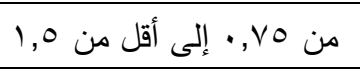 & متوسطة \\
\hline من · إلى أقل من Vo, . & منخفضة \\
\hline
\end{tabular}

طريقة تفسير نتائج الدراسة: لتفسير نتائج الدراسة حدد الباحث معياراً عند تفسير ومناقشة النتائج وفقاً

جدول (0): معيار الاستجابات والمتوسط الحسابي لارجات السلم الرباعي

درجة تقييم مبادئ المواطنة الرقمية في الصفحات

الرسمية للجامعات موضع الدراسة تكون عالية جداً

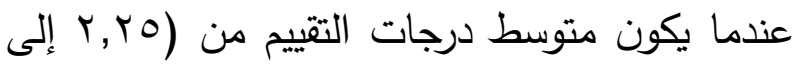

درجة تقييم مبادئ المواطنة الرقمية في الصفحات

الرسمية للجامعات موضع الدراسة تكون عالية عندما

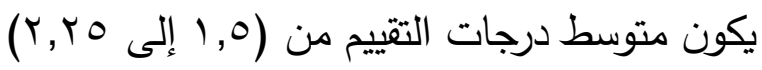


جدول (؟) نتائج المعالجة الإحصائية لعبارات محور الوصول الرقمي والمحور ككل

\begin{tabular}{|c|c|c|c|c|c|}
\hline \multicolumn{5}{|c|}{ المحور الأول: الوصول الرقمي } & \multirow{2}{*}{ تالقيمة } \\
\hline التسلسل & مستوى & 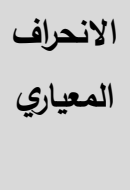 & 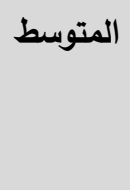 & العبارة & \\
\hline 5 & عالية جداً & 0.54 & 2.90 & إتاحة قنوات اتصال إلكترونية مختلفة بين أعضاء هيئة التثربس والطلبة. & 1 \\
\hline 3 & عالية جداً & 1.29 & 2.30 & معالجة مشكلات الطلبة في التعامل مع المصادر الرقية المختلفة. & 2 \\
\hline 7 & منفضضة & 0.65 & 0.30 & تضتمين إثارات توعوية لتوضيح الاستخدام الأمثل لتقنيات الاتصال الرقمي & 3 \\
\hline 6 & منخفضة & 0.40 & 0.20 & تنظيم برامج تدريبية للطلاب عن أساليب وطرق الاتصال الرقمي. & 4 \\
\hline 2 & منخفضة & 0.76 & 0.20 & التعريف بأدوات الاتصال وبائلها الدختلفة. & 5 \\
\hline 1 & منففضة & 0.25 & 0.07 & استذذام محركات البحث لذذمة العملية التعليمية. & 6 \\
\hline 4 & منفضضة & 0.00 & 0.00 & مشاركة المعرفة الرققية الخاصة بالجامعة مع المجتمع. & 7 \\
\hline & متوسط & & 0.85 & & إجمالي \\
\hline
\end{tabular}

المجتمعية التي تقوم بها الجامعات السعودية داخل المجتمع المحيط بالجامعة، وعدم توجيه الطلاب لهاب لهابل

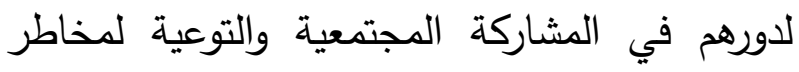
الاستخدام السيء للتكنولوجيا الرقمية. السؤال البحثي الثاني والذي ينص على:" ما درجة التهاء

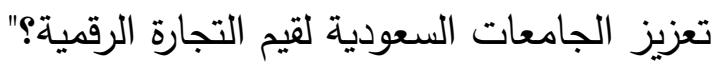

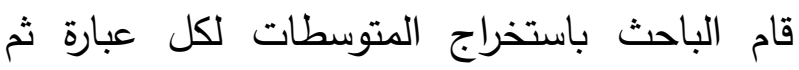
Spss المتوسط الكلي لهذا المحور باستخدام برنامج للمعالجة الإحصائية وذلك كما يوضحه جدول(V)
ويظهر في الجدول (؟) العبارات التي يتضمنها المحور الأول وعددها (V) عبارات وقد ترتبت هذه لفي

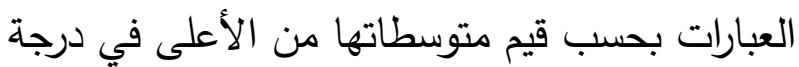

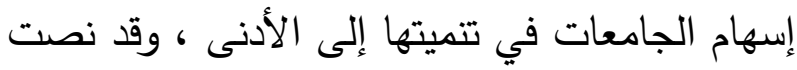

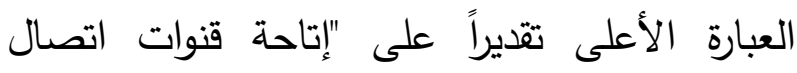
إلكترونية مختلفة بين أعضاء هيئة التدريس والطلبة"، وهذا يرجع لاهتمام الجامعات السعودية بتوافر قنوات

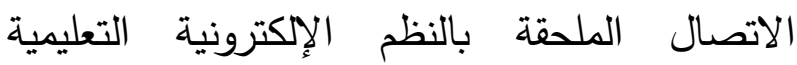
والصفحات الرسمية لها لتسهل التواصل بين الطلاب التبال و أساتنتهم في العملية التعليمية، بينما كانت العبارة التي تتص على" مشاركة المعرفة الرقمية الخاصة

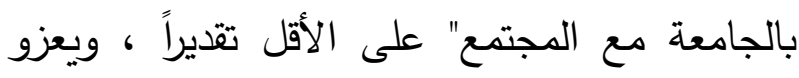
الباحث انخفاض هذه العبارة إلى ندرة الأنشطة لهيتة 
جدول (V) نتائج المعالجة الإحصائية لعبارات محور التجارة الرقمية والمحور ككل

\begin{tabular}{|c|c|c|c|c|c|}
\hline \multicolumn{5}{|c|}{ المحور الثاني: التجارة الرقمية } & \multirow{2}{*}{ ترتيب } \\
\hline في البطاقة & تحقق القيمة & 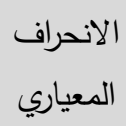 & 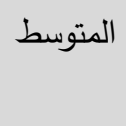 & 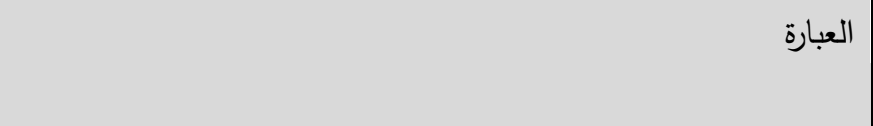 & \\
\hline 13 & منخفضة & 0.48 & 0.20 & التوجيه بترشيد التعامل مع مواقع التسوق الإلكترونية. & 1 \\
\hline 12 & منخفضة & 0.48 & 0.20 & للحسابات الثخصية، ...... وغيرها التشاط الإكتروني من عمليات السرقة، واختراق & 2 \\
\hline 11 & منخفضة & 0.46 & 0.17 & عقد ندوات ولقاءات حول كيفية التعامل الصحيح مع مواقع التسوق الإلكترونية. & 3 \\
\hline 8 & منخفضة & 0.43 & 0.13 & توعية الطلبة عن ضرورة انتقاء المواقع التجارية الإكترونية الأمنة. & 4 \\
\hline 9 & منخفضة & 0.40 & 0.10 & توضيح أهم مؤشرات المصداقية لمواقع التجارة الإكترونية. & 5 \\
\hline 10 & منخفضة & 0.40 & 0.10 & وقتمانين الوعي لدى الطلبة نحو بيع وشراء الدنتجات التي تتعارض مع أنظمة & 6 \\
\hline & منخفض & & 0.15 & لمحور & |إجمالي | \\
\hline
\end{tabular}

الدولة" على الأقل تقديراً ، وذلك يعود إلى عدم إقامة الجامعات ندوات ثقافية لما يتعلق بشراء المنتجات عبر المواقع التجارية الرقمية وبالتالي ندرة الإشارة التوعوية لما يتعلق بالقوانين والمنتجات المحظورة في الدولة. السؤال البحثي الثالث والذي ينص على:" ما درجة تعزيز الجامعات السعودية لقيم الاتصالات الرقمية؟" قام الباحث باستخراج المتوسطات لكل عبارة ثم Spss المتوسط الكلي لهذا المحور باستخدام برنامج للمعالجة الإحصائية وذلك كما يوضحه جدول(^)
ويظهر في الجدول (V) العبارات التي يتضمنها المحور الثاني وعددها (T) عبارات، وقد ترتبت هذه العبارات بحسب قيم متوسطاتها من الأعلى في درجة إسهام الجامعات في تنميتها إلى الأدنى، وقد نصت العبارة الأعلى تقديراً على "التوجيه بترشيد التعامل مع مواقع التسوق الإكترونية"، وهذا يرجع للانفتاح التجاري الحاصل في العصر الحالي والذي قد يتسبب في العديد من المخاطر خاصة لأصحاب الخبرة الضعيفة بحقوقهم وواجباتهم نحو المعاملات التجارية الرقمية، لذا فمن دور الجامعات توعية طلابها بهذا الشأن تفادياً للمخاطر ولحمايتهم منها، بينما كانت العبارة التي تتص على " تنمية الوعي لدى الطلبة نحو بيع وشراء المنتجات التي تتعارض مع أنظمة وقوانين 
جدول (^) نتائج المعالجة الإحصائية لعبارات محور الاتصالات الرقمية والمحور ككل

\begin{tabular}{|c|c|c|c|c|c|}
\hline \multicolumn{5}{|c|}{ المحور الثالث: الاتصالات الرقمية } & \multirow[b]{2}{*}{ ترتيب } \\
\hline التسلسل & مستوى & الانعراف & 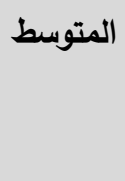 & 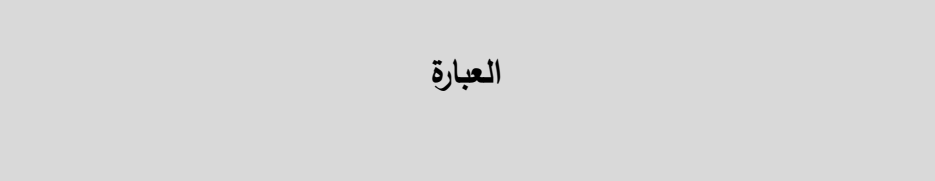 & \\
\hline 18 & عالية & 1.00 & 0.76 & 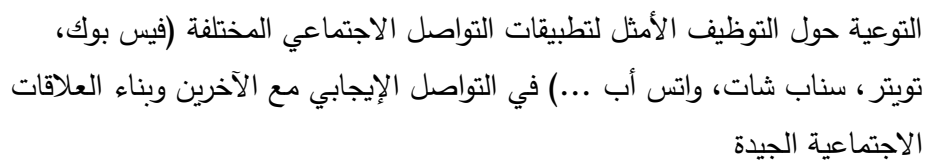 & 1 \\
\hline 17 & عالية & 1.00 & 0.76 & التوعية بالسلوكيات والآداب الصحيحة عند استخدام تقنيات الاتصال الرقمي المختلفة & 2 \\
\hline 19 & منخفضة & 1.00 & 0.60 & التوعية بضوابط ومحددات بناء العلاقات الاجتماعية مع الآخرين عبر الشبكة. & 3 \\
\hline 15 & منخفضة & 0.93 & 0.53 & نشر الوعي بأهمية تحديد الأهداف الأساسية للاتصال مع الآخرين. & 4 \\
\hline 14 & منخفضة & 0.97 & 0.50 & التعريف بمختلف تقنيات التواصل الرقمي. & 5 \\
\hline 20 & منخفضة & 0.81 & 0.40 & تتمية مهارات التعلم التشاركي بين الطلبة عبر تطبيقات الاتصال الرقمي المتاحة. & 6 \\
\hline 16 & منخفضة & 0.60 & 0.33 & معرفة طرق الاتصالات الرقمية الملائمة وغير الملائمة. & 7 \\
\hline 21 & منخفضة & 0.18 & 0.03 & توعية الطلبة بطرق استرجاع الملفات والبيانات المحذوفة. & 8 \\
\hline & منخفض & & 0.49 & 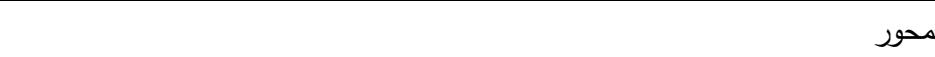 & 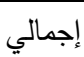 \\
\hline
\end{tabular}

التي تنص على" توعية الطلبة بطرق استرجاع الملفات والبيانات المحذوفة." على الأقل تقديراً، ويرجع ذلك لقلة خبرة الطلاب في التعامل مع البرمجيات المعنية باسترجاع الملفات المحذوفة، وقلة مشاركة الجامعات السعودية للتوعية بالمخاطر المترتبة على ضياع

$$
\text { البيانات والملفات المحذوفة. }
$$

السؤال البحثي الرابع والذي ينص على:" ما درجة تعزيز الجامعات السعودية لقيم محو الأمية الرقمية؟" قام الباحث باستخراج المتوسطات لكل عبارة ثم Spss المتوسط الكلي لهذا المحور باستخدام برنامج للمعالجة الإحصائية وذلك كما يوضحه جدول(9)
ويظهر في الجدول (^) العبارات التي يتضمنها المحور الثالث وعددها (^) عبارات، وقد ترتبت هذه العبارات بحسب قيم متوسطاتها من الأعلى في درجة إسهام الجامعات في تتميتها إلى الأدنى ، وقد نصت العبارة الأعلى تقديراً على "التوعية حول التوظيف الأمثل لتطبيقات التواصل الاجتماعي المختلفة (فيس بولك، تويتر ، سناب شات، واتس أب ...) في التواصل الإيجابي مع الآخرين وبناء العلاقات الاجتماعية الجيدة."، وهذا يعود إلى تصميم الصفحات الرسمية للجامعات حيث تتضمن معظم تطبيقات التواصل الاجتماعي لتسهيل التواصل مع الآخرين داخل نظام التعلم الخاص بالجامعة دون الحاجة للخروج منه وذلك بهدف خلق بيئة تعليمية متكاملة، بينما حصلت العبارة 
جدول (9) نتائج المعالجة الإحصائية لعبارات محور محو الامية الرقية والمحور ككل

\begin{tabular}{|c|c|c|c|c|c|}
\hline \multicolumn{5}{|c|}{ المحور الرابع: محو الأمية الرقمية } & \multirow{2}{*}{ ترتيب } \\
\hline في البطاقة & مستوى & 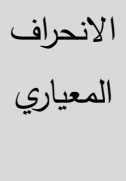 & المتوسط & 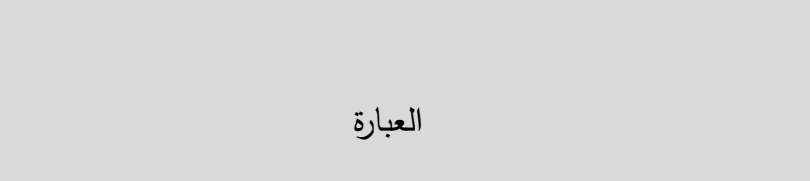 & \\
\hline 22 & منخفضة & 0.18 & 0.33 & تتمية الوعي بأهية تعلم مهارات استخدام التكنولوجيا الرقمية. & 1 \\
\hline 24 & منخفضة & 0.52 & 0.26 & تزويد الطلبة بالمعلومات التي تؤهلهم لاستخدام الاتصالات الرقمية. & 2 \\
\hline 26 & منخفضة & 0.58 & 0.26 & توعية الطلبة بدورهم المأمول في نشر الثقافة الرقمية في أوساطهم & 3 \\
\hline 23 & منخفضة & 0.37 & 0.16 & تقديم أحدث مستجدات تكنولوجيا التعليم والاتصال. & 4 \\
\hline 25 & منخفضة & 0.46 & 0.16 & في النواحي النظار الطلبة لتعلم كيفية الاستفادة من تكنولوجيا الاتصالات الرقمية & 5 \\
\hline & 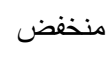 & & 0.18 & \multicolumn{2}{|c|}{ إجمالي المحور } \\
\hline
\end{tabular}

ويظهر في الجدول (9) العبارات التي يتضمنها استتجه الباحث من تحليله للمواد الإعلانية

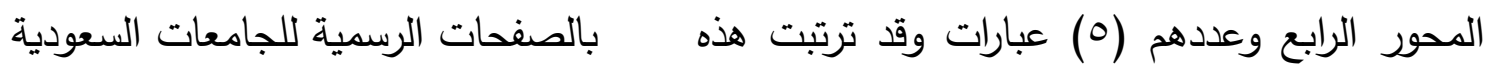

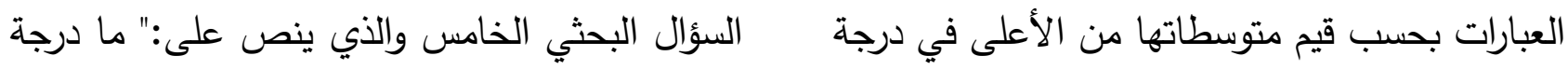

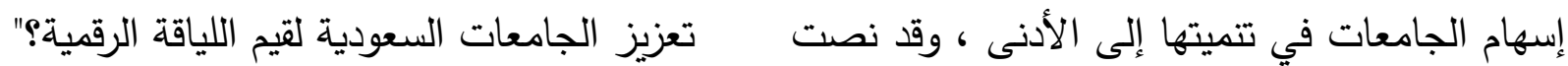

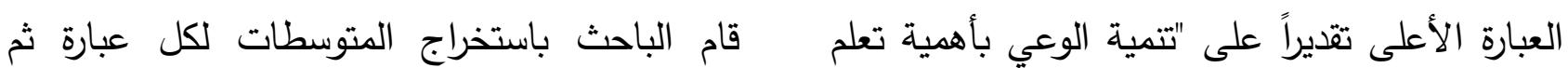

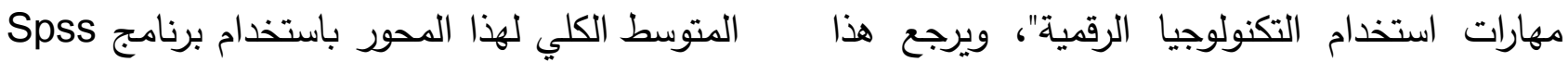
التقدير المرتفع لما لمسه الباحث من اتجاهات إيجابية للمعالجة الإحصائية وذلك كما يوضحه جدول(· • (). للجامعات السعودية بخصوص هذا الثأن للقضاء على الامية الرقمية بين الطلاب وذلك عن طريق عقد فئد

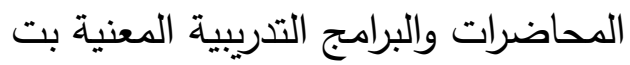
علم مهارات استخدام التكنولوجيا الرقمية، بينما حصلت العبارة التي تتص على" تقديم أحدث مستجدات تكنولوجيا التعليم والاتصال." على الأقل تقديراً، وقد يرجع هذا لعدم التفات أغلب الجامعات لمستجدات تكنولوجيا التعليم والاتصال وهذا ما لهات 
جدول (• 1) نتائج المعالجة الإحصائية لعبارات محور اللياقة الرقمية والمحور ككل

\begin{tabular}{|c|c|c|c|c|c|}
\hline \multicolumn{5}{|c|}{ المحور الخامس: اللياقة الرقمية } & \multirow{2}{*}{ ترتيب - (القيمة } \\
\hline 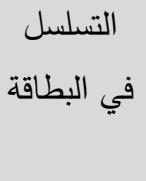 & مستوى & المعياري & المتوسط & 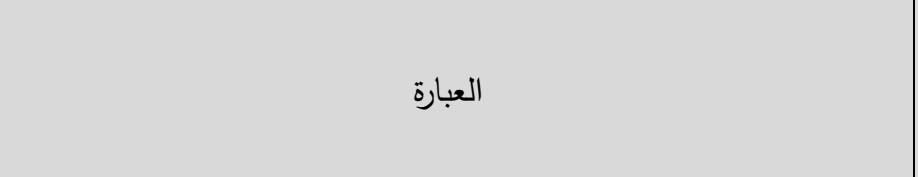 & \\
\hline 29 & منخفضة & 0.99 & 0.63 & الثخصية وعي الطلبة بأثكال السلوك غير المقبول في المجتمعات الرقمية كانتحال & 1 \\
\hline 28 & 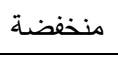 & 0.85 & 0.43 & تقديم برامج إرشادية حول أهمية ضبط السلوك وأخلاقيات استخدام التقنيات الرقمية. & 2 \\
\hline 27 & منخفضة & 1.69 & 0.43 & تقديم فيديوهات تعليمية حول طرق التعامل الواعي مع الأجهزة الرقمية. & 3 \\
\hline 30 & منخفضة & 0.85 & 0.36 & توجيه الطلبة إلى طرق وأساليب التصدي لأي سلوك غير مقبول قد يتعرضون له & 4 \\
\hline 31 & منخفضة & 1.64 & 0.33 & ترضك المجال لمشاركة الطلبة في وضع السياسات التي يجب اتباعها أثناء تواصل & 5 \\
\hline 32 & منخفضة & 1.64 & 0.30 & تلى تلويد الطلبة بالطرق والأساليب المناسبة التي تمكنهم من نشر السلوكيات المقبولة & 6 \\
\hline & منخفض & & 0.41 & \multicolumn{2}{|c|}{ إجمالي المحور } \\
\hline
\end{tabular}

أبرز الجرائم الرقمية في العصر الحالي، بينما حصلت

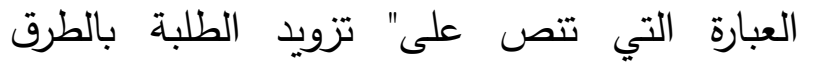
والأساليب المناسبة التي تمكنهم من نشر السلوكيات

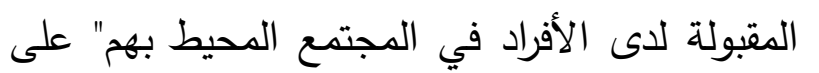

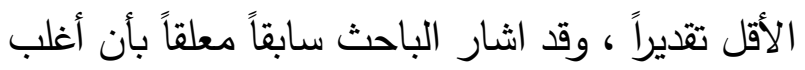
الجامعات السعودية لا تقوم بتحفيز الطلاب للقيام

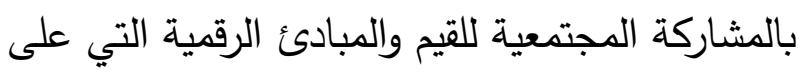
المجتمع كافة الإلمام بها. السؤال البحثي السادس والذي ينص على الإم:" ما درجة

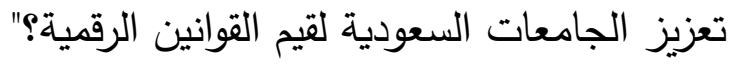

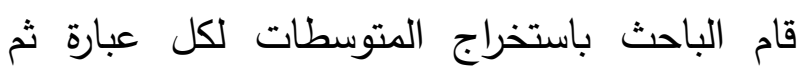

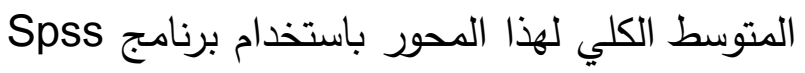

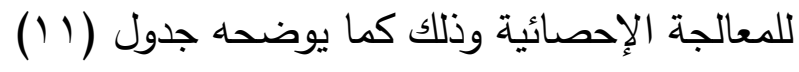

ويظهر في الجدول (·•) العبارات التي يتضمنها المحور الخامس وعددها (T) عبارات، وقد ترتبت هذه العبارات بحسب قيم متوسطاتها من الأعلى في درجة وته ترتي

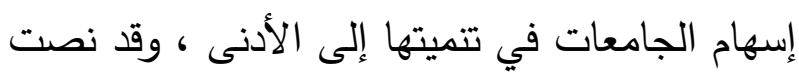
العبارة الأعلى تقديراً على "تتمية وعي الطلبة بأشكال السلوك غير المقبول في المجتمعات الرقمية كانتحال الثخصيات ونشر الثائعات وتبادل الصور والرئيعات الثرئل غير المناسبة"، فقد كانت هذه المهمة من أبرز المهمات التي تولتها أغلب الجامعات السعودية فقد التداه دعمتها بالعديد من الإجراءات مثل عقد الندوات والمؤتمرات ونشر الرسائل والمقالات التربوية للتوعية

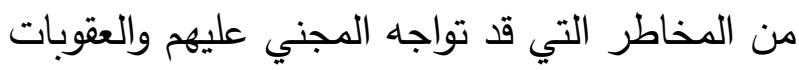
التي يسقطها القانون على الجناة، فانتحال الثخصيات

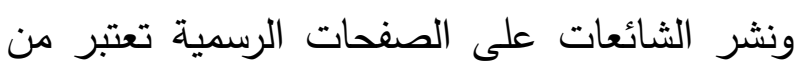


جدول (1 1) نتائج المعالجة الإحصائية لعبارات المحور السادس والمحور ككل

\begin{tabular}{|c|c|c|c|c|c|}
\hline \multicolumn{5}{|c|}{ المحور السادس: القوانين الرقمية } & \multirow{2}{*}{ ترتيب } \\
\hline في البطاقة & تحقق القيمة & المعياري & المتوسط & 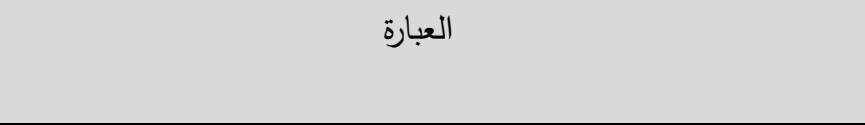 & \\
\hline 38 & منخفضة & 0.89 & 0.56 & 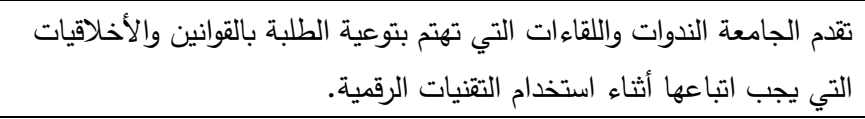 & 1 \\
\hline 37 & منخفضة & 0.89 & 0.53 & والأفكار المنحرفة. من الانضمام أو التعامل مع الصفحات الرقمية التي تروج الثائعات & 2 \\
\hline 34 & منخفضة & 0.73 & 0.44 & تقديم برامج توعوية حول المخاطر التي قد يتعرض لها الطلبة أثناء تعاملهم مع & 3 \\
\hline 36 & منخفضة & 0.85 & 0.40 & التحذير من متابعة الحسابات الإككترونية المشبوهة & 4 \\
\hline 33 & منخفضة & 0.61 & 0.36 & تتمية الوعي لاى الطلبة حول أنواع الجرائم المشهورة في المجتمعات الرقمية. & 5 \\
\hline 35 & منخفضة & 0.40 & 0.20 & تعريف الطلبة بخطوات وإجراءات الإبلاغ عن أي عمل غير قانوني عبر & 6 \\
\hline 39 & منخفضة & 0.30 & 0.10 & توضيح المسؤولية التي تقع على الطالب أثناء التعامل مع التطبيقات الرقمية. & 7 \\
\hline & 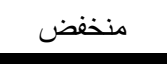 & & 0.37 & محور & إجمالي \\
\hline
\end{tabular}

تعزيز مبادئ وأخلاقيات استخدام التقنيات الرقمية، بينما حصلت العبارة التي تتص على" توضيح المسؤولية التي تقع على الطالب أثناء التعامل مع التطبيقات الرقمية" على الأقل تقديراً، وترجع قلة تقدير هذه العبارة لقلة نشر أغلب الجامعات السعودية ثقافة مسؤولية الطلاب حول تعاملهم مع التطبيقات الرقمية. السؤال البحثي السابع والذي ينص على:" ما درجة تعزيز الجامعات السعودية لقيم الحقوق والمسؤوليات

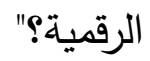
قام الباحث باستخراج المتوسطات لكل عبارة ثم Spss المتوسط الكلي لهذا المحور باستخدام برنامج للمعالجة الإحصائية وذلك كما يوضحه جدول (r)
ويظهر في الجدول (1) العبارات التي يتضمنها المحور السادس وعددها (V) عبارات، وقد ترتبت هذه العبارات بحسب قيم متوسطاتها من الأعلى في درجة إسهام الجامعات في تتميتها إلى الأدنى ، وقد نصت العبارة الأعلى تقديراً على "تقدم الجامعة الندوات واللقاءات التي تهتم بتوعية الطلبة بالقوانين والأخلاقيات التي يجب اتباعها أثناء استخدام التقنيات الرقمية"، ويرجع ارتفاع تقدير هذه العبارة لما وجده الباحث بعد تحليل للمواد الإعلانية بالصفحات الرسمية للجامعات السعودية، فقد أهتمت أغلب الجامعات السعودية بإقامة الندوات والمؤتمرات واللقاءات والورش التدربيية التي تعمل على 
جدول (r I ) نتائج المعالجة الإحصائية لعبارات المحور السابع والمحور ككل

\begin{tabular}{|c|c|c|c|c|c|}
\hline \multicolumn{5}{|c|}{ المحور السابع: الحقوق والمسؤوليات الرقمية } & \multirow{2}{*}{ القيمة } \\
\hline في البطاقة & تحقق القيمة & الانحراف & المتوسط & 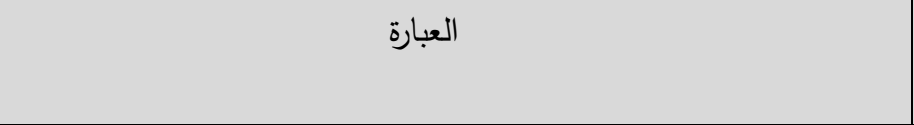 & \\
\hline 40 & منخفضة & 0.48 & 0.20 & تعريف الطلبة بحقوقهم ومسؤولياتهم في العالم الرقمي الافتراضي. & 1 \\
\hline 41 & منخفضة & 0.00 & 0.00 & تإليها. & 2 \\
\hline 42 & منخفضة & 0.00 & 0.00 & تحذير الطلبة من نشر الثائعات عبر التطبيقات الرقمية أو نشر الأخبار قبل التأكد & 3 \\
\hline 43 & منخفضة & 0.00 & 0.00 & شرح طرق وأساليب التعامل مع الثائعات والأفكار غير المقبولة وآليات الاستعداد & 4 \\
\hline 44 & منخفضة & 0.00 & 0.00 & تحذير الطلبة من انتهاك الحقوق الخاصة بالصفحات الرقمية للآخرين. & 5 \\
\hline 45 & منخفضة & 0.00 & 0.00 & توضيح الحقوق والمسؤوليات الرقمية في الفصول الافتراضية لأنظمة التعليم & 6 \\
\hline & 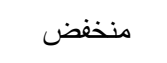 & & 0.03 & 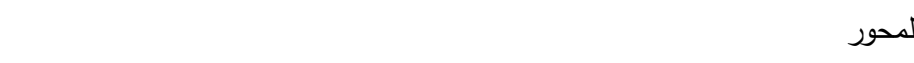 & 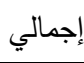 \\
\hline
\end{tabular}

ويظهر في الجدول (r) العبارات التي يتضمنها السؤال البحثي الثامن والذي ينص على:" ما درجة

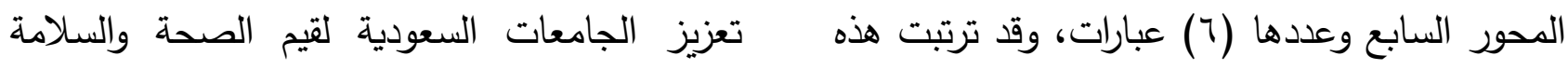

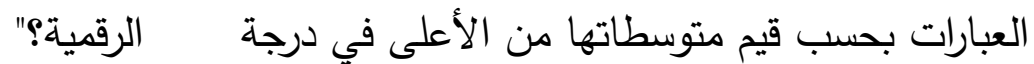

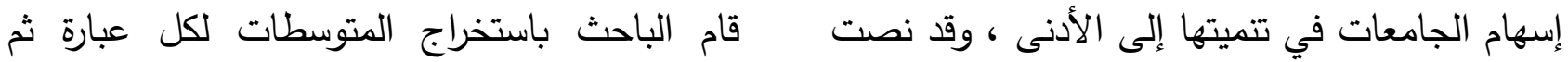

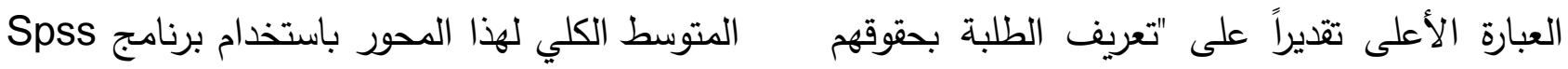

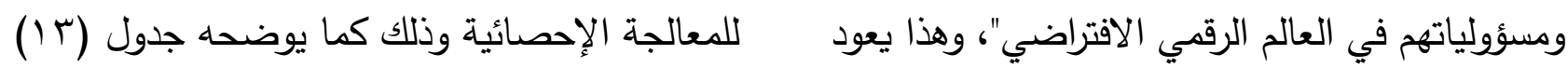
لالتفات معظم الجامعات السعودية لإقامة الندوات

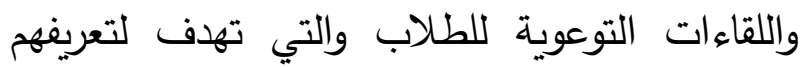
بحقوقهم ومسؤولياتهم أثناء استخدامهم للتكنولوجيا

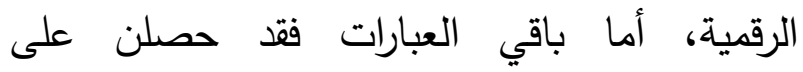
المتوسط( ·, •) أي انعدام الاستجابة من الغالبية

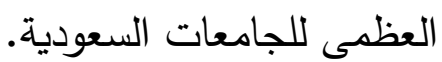


جدول (T I ) نتائج المعالجة الإحصائية لعبارات المحور الثامن والمحور ككل

\begin{tabular}{|c|c|c|c|c|c|}
\hline \multicolumn{5}{|c|}{ المحور الثامن: الصحة والسلامة الرقمية } & \multirow{2}{*}{ ترتيب } \\
\hline التسلسل & تحقتى & الانحر المعياري & المتوسط & 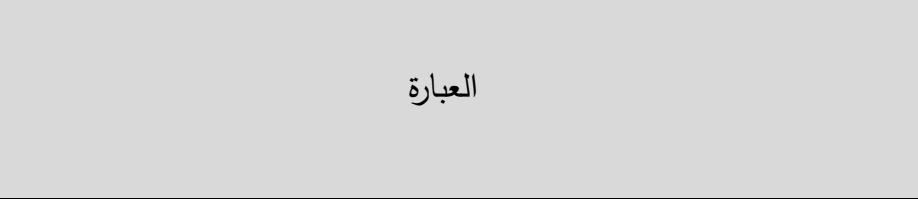 & \\
\hline 46 & منخفضة & 0.00 & 0.00 & توضيح الطرق السليمة للاستخدام الصحي للتكنولوجيا من خلال البرامج الإرشادية & 1 \\
\hline 47 & منخفضة & 0.00 & 0.00 & توضيح المخاطر الصحية البدنية التي قد يسببها الاستخدام غير الراشد للتكنولوجيا & 2 \\
\hline 48 & منخفضة & 0.00 & 0.00 & توجيه الطلبة إلى ضرورة مراعاة وإدارة الوقت عند استخدام التكنولوجيا الرقمية لتجنب & 3 \\
\hline 49 & منخفضة & 0.00 & 0.00 & التنبيه إلى سلبية الإفراط في استخدام الألعاب الإلكترونية تجنباً لأضرارها في ضياع & 4 \\
\hline 50 & منخفضة & 0.00 & 0.00 & توجيه الطلبة ليقوموا بدورهم المجتمعي بنشر ثقافة الصحة والسلامة الرقمية. & 5 \\
\hline 51 & منخفضة & 0.00 & 0.00 & توضيح المخاطر البدنية للجلوس الخاطئ أثناء التعامل مع التطبيقات الرقمية. & 6 \\
\hline \multirow[t]{2}{*}{52} & منخفضة & 0.00 & 0.00 & عقد ندوات ولقاءات تتمحور حول مخاطر الإدمان التكنولوجي للتطبيقات الرقمية. & 7 \\
\hline & منخفض & 0.00 & 0.00 & \multicolumn{2}{|c|}{ 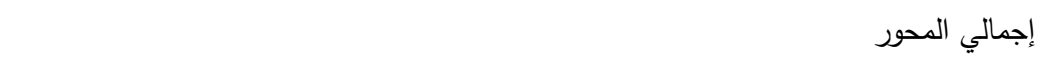 } \\
\hline
\end{tabular}

ويظهر في الجدول (rا) العبارات التي يتضمنها التدريب التربوي بتتمية وتعزيز مبادئ الصحة المحور الثامن وعددها (V) عبارات وقد حصلت جميع والسلامة الرقمية.

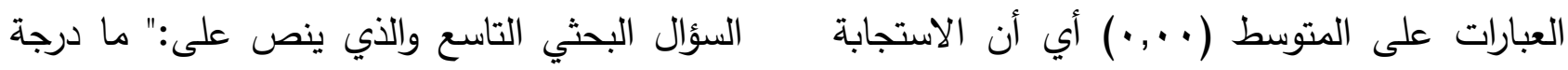

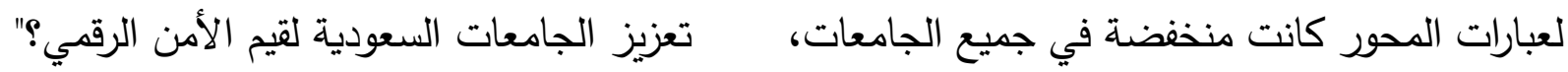

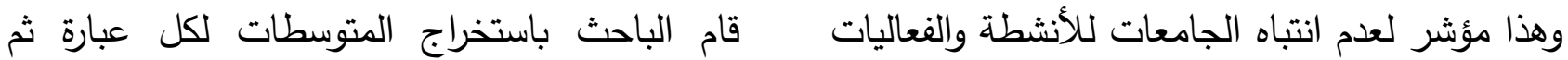

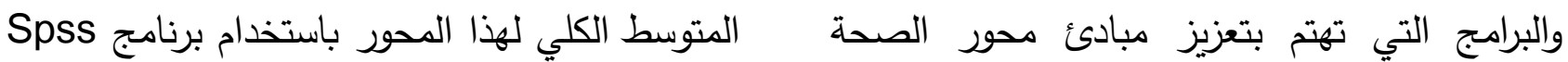
والسلامة الرقمية، وهذا يتفق مع دراسة آل للمعالجة الإحصائية وذلك كما يوضحه جدول (ع ( )

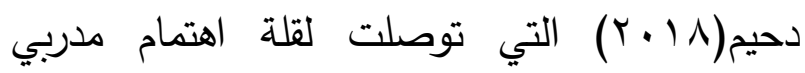


جدول (ع 1) نتائج المعالجة الإحصائية لعبارات المحور التاسع والمحور ككل

\begin{tabular}{|c|c|c|c|c|c|}
\hline \multicolumn{5}{|c|}{ المحور التاسع: الأمن الرقمي } & \multirow{2}{*}{ ترتيب } \\
\hline التسلسل & مستوى & 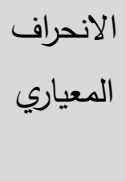 & المتوسط & 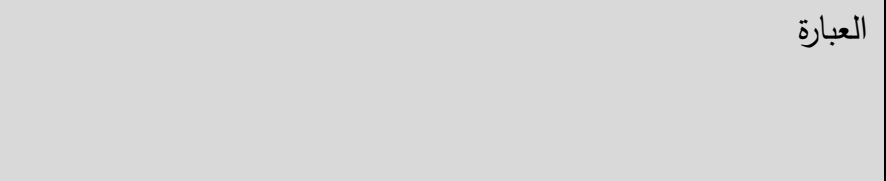 & \\
\hline 53 & منخفضة & 0.00 & 0.00 & الرقمية الخاصة بهم. & 1 \\
\hline 54 & منخفضة & 0.00 & 0.00 & وأعضاء هيئة التدريس. تلتصى الثكاوى الخاصة بالحماية والأمان لحسابات الطلبة & 2 \\
\hline 55 & منخفضة & 0.00 & 0.00 & من خلال التطبيقات المتاحة على مالية من الحماية والأمان في تعاملات الطلبة مع بعضهم & 3 \\
\hline 56 & منخفضة & 0.00 & 0.00 & توضيح أهمية اختيار كلمات مرور قوية لحساباتهم الرقمية. & 4 \\
\hline 57 & منخفضة & 0.00 & 0.00 & توجيه الطلبة نحو نشر ثقافة الأمن والحماية الرقمية في المجتمع المحيط & 5 \\
\hline 58 & منخفضة & 0.00 & 0.00 & الأخرين الرقمية. & 6 \\
\hline & منخفض & 0.00 & 0.00 & 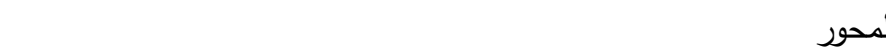 & إجمالي \\
\hline
\end{tabular}

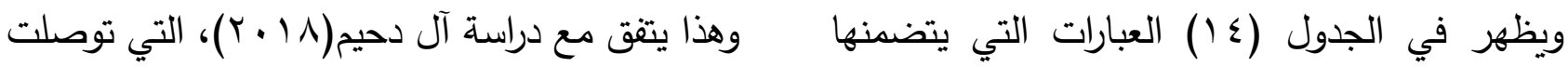
المحور التاسع وعددها (T) عبارات وقد حصلت جميع إلى قلة اهتمام مدربي التدريب التربوي بتعزيز مبادئ

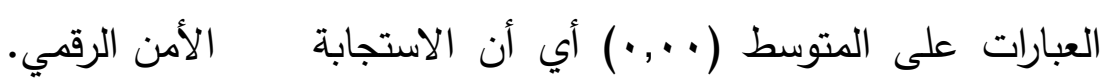

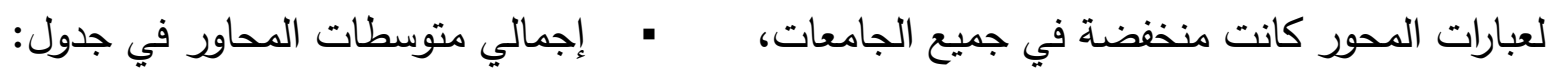
وهذا مؤشر لعدم انتباه الجامعات للأنشطة والفعاليات والبرامج التي تهتم بتعزيز مبادئ محور الأمن الرقمي، 
جدول (0 10) نتائج كل محور وترتيبها بحسب المتوسطات، ومستوى تقييم كل محور

\begin{tabular}{|c|c|c|c|c|}
\hline تقييم مستوى المحاور & الترتيب & المتوسط & 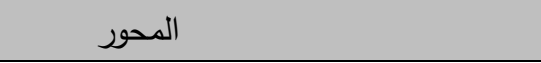 & 5 \\
\hline متوسط & 1 & 0.85 & المحور الأول: الوصول الرقمي & 1 \\
\hline منخفض & 2 & 0.49 & المحور الثالث: الاتصالات الرقمية & 3 \\
\hline منخفض & 3 & 0.41 & المحور الخامس: اللياقة الرقمية & 5 \\
\hline منخفض & 4 & 0.37 & المحور السادس: القوانين الرقمي & 6 \\
\hline منخفض & 5 & 0.18 & المحور الرابع: محو الأمية الرقمية & 4 \\
\hline منخفض & 6 & 0.15 & المحور الثاني: التجارة الرقمية & 2 \\
\hline 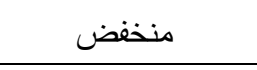 & 7 & 0.03 & المحور السابع: الحقوق والمسؤوليات الرقمية & 7 \\
\hline منخفض & 8 & 0.00 & المحور الثامن: الصحة والسلامة الرقمية & 8 \\
\hline منخفض & 9 & 0.00 & المحور التاسع: الأمن الرقمي & 9 \\
\hline
\end{tabular}

إلى اتبي برامج وخطط فاعلة في تتمية وتعزيز مبادئ المواطنة الرقمية، ومراجعة برامجها الحالية ذات العلاقة بمبادئ المواطنة الرقمية. السؤال البحثي العاشر والذي ينص على:" هل هناك فروق ذات دلالة إحصائية بين متوسطات درجات تضمين الجامعات السعودية لمبادئ المواطنة الرقمية في صفحتها الإلكترونية الرسمية تعزى لمتغير العمر الزمني للجامعة؟" قام الباحث باستخدام تحليل التباين One way Anova متوسطات درجات تعزيز المواطنة الرقمية للى الجامعات السعودية بحسب العمر الزمني للجامعات، وذلك باستخدام برنامج Spss للمعالجة الإحصائية وذلك كما يوضحه جدول (7 (1).
يظهر في جدول(0) المحاور التسعة لأداة الدراسة وقد ترتبت هذه المحاور بحسب المتوسط الذي حصل عليه كل محور ، حيث حصل المحور الأول" الوصول الرقمي" على الأعلى متوسط بين المحاور، ليتفوق على باقي محاور الاستبانة بحصوله على متوسط (10, •)، وهذا يتفق مع ما ورد في دراسة الشمري

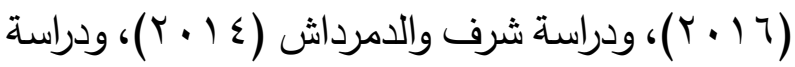

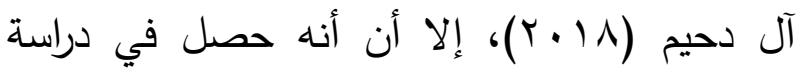
القحطاني(1 ( r) على الترتيب الثالث ، بينما حصل المحورين الثامن والتاسع على أقل متوسط بين المحاور فتتفق هذه النتيجة دع دراسة آل دحيم حيث حصل محور (الصحة والسلامة (r.11) الرقمية)، ومحور (الأمن الرقمي) على أقل تقدير، بينما اختلفت هذه النتيجة مع دراسة القحطاني(1 ( • ب) حيث حصلا على الترتيب الرابع والخامس على التوالي، وهو مؤشر على حاجة الجامعات السعودية 
جدول (4 1 ) نتائج تحليل التباين لقياس فروق المتوسطات بين الجامعات بحسب العمر الزمني للجامعة

\begin{tabular}{|c|c|c|c|c|c|c|}
\hline الدلالة & قيمة (ف) & الانحراف & المتوسط & العدد العد & الجامعات بحسب العمر الزمني & s \\
\hline \multirow{4}{*}{0.174} & \multirow{4}{*}{1.870} & 0.13 & 0.22 & 8 & جامعات ناشئة & 1 \\
\hline & & 0.36 & 0.39 & 14 & جامعات حديثة & 2 \\
\hline & & 0.14 & 0.18 & 8 & جامعات قديمة & 3 \\
\hline & & 0.27 & 0.292 & 30 & نتائج الجامعات ككل & \\
\hline
\end{tabular}

والذي يعتقد الباحث بأن يرجع إلى تبني وزارة التعليم بالمملكة العربية السعودية عامة لتكنولوجيا الاتصال والتواصل الرقمي ودمجها في التعليم وبرامجها، وهو

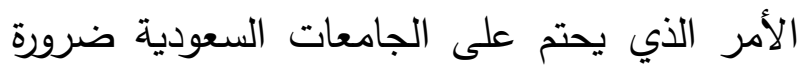
تنمية الوعي بطرق الاتصال الرقمي وآداب التواصل الرقمي وحقوق وواجبات كل فرد تجاه باقي الافراد في البيئة الرقمية ، كي لا يترتب على ضعف هذه المبادئ حدوث أي مشكلات تؤثر على جودة الاتصال الرقمي لآلئي وتحقيقه لأهدافه المثلى. ץ- حصول ثلاثة محاور هي: الثاني " التجارة الرقمية"، والرابع " محور الأمية الرقمية"، والسادس " لهابه القوانين الرقمية"، على متوسطات منخفضة لكنها تقع قي المنتصف بين المجموعة الأعلى والمجموعة الأقل، ويرجع ذلك إلى قلة البرامج الموجهة نحو مبادئ التجارة الرقمية، والقوانين الرقمية، ويعزو الباحث ذلك لاعتبار هذه الجوانب مما يتوقع من طالب المرحلة

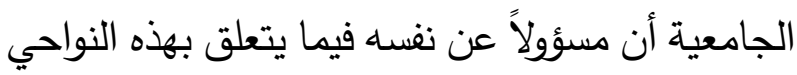
حيث تعدد الطرق التي يمكن للطلاب تعلم تكنولوجيا
ويظهر في جدول(7 (1) نتائج اختبار تحليل التباين لمجموعات الجامعات السعودية المقسمة بحسب العمر الزمني للجامعات، وقد تبين من الجدول أن الدلالة

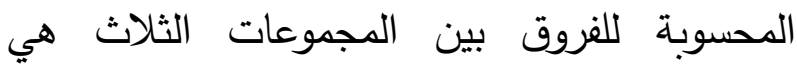

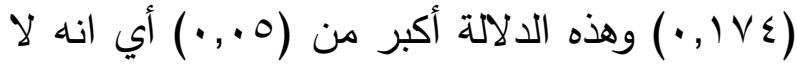
توجد دلالة للفرق بين متوسطات الجامعات السعودية تعزى لمتغير العمر الزمني للجامعات فقد حصلت الجامعات على متوسطات متقاربة، إلا أن الجامعات الحديثة قد حصلت على المتوسط الأعلى وقد يعزى الهى اند الهات ذلك لفارق العدد لهذه المجموعة عن غيرها حيث تمثلت في (ع ()) جامعة بينما كان عدد كلا من الجامعات القديمة والناشئة (^) جامعات فقط. ملخص نتائج الاراسة: تتلخص نتائج الدراسة في النقاط التالية: 1- حصول ثلاثة محاور هي: الأول "الوصول

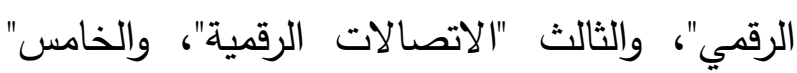
اللياقة الرقمية" على المتوسطات الأكبر من بين المحاور التسعة المتمثلة في مبادئ المواطنة الرقمية، 


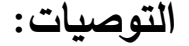

في ضوء نتائج الدراسة الحالية يوصي الباحث بما يلي:

1- أهمية عناية الجامعات السعودية بمبادئ المواطنة الرقمية الأقل تعزيزاً والمتمثلة في مبدأي الأمن الرقمي،

والصحة والسلامة الرقمية.

Y- إجراء المزيد من الدراسات حول إسهامات الجامعات السعودية في تعزيز قيم المواطنة الرقمية من

خلال الصفحات الإلكترونية الرسمية للجامعات. r- إجراء البحوث التجربية التي تهدف لتعزيز مبادئ المواطنة الرقمية من خلال طرق واستراتيجيات مختلفة تعمل على غرس هذه المبادئ في شخصيات وممارسات المتعلمين. ع- الاطلاع على ما تقوم به الجامعات ذات المستوى الأكاديمي والتصنيف العالي حول العالم ومعرفة الطرق التي تقوم بها لتعزيز مبادئ المواطنة الرقمية. 0- تعزيز مبادئ المواطنة الرقمية لدى القيادات والأساتذة الأكاديميين حتى يتسنى لهح نقل خبراتهم للمتعلمين. ד- إدراج مساقات تدريسية حول المواطنة الرقمية في برامج الجامعات السعودية.

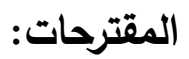

في سبيل تعزيز مبادئ وقيم المواطنة الرقمية يقترح الباحث إجراء البحوث التالية: 1- إجراء دراسة تهدف للتعرف على درجة وعي طلاب الجامعات السعودية بقيم المواطنة الرقمية.
الاتصال الرقمية من خلالها مثل بيئات التواصل الأخرى خارج نطاق التعليم الجامعي، لذلك جعلت الجامعات السعودية الأولوية لتوعية للطلاب على أساليب الاتصال الرقمي والوصول الرقمي أكثر من التجارة الرقمية والقوانين الرقمية. r- حصول ثلاثة محاور هي: السابع" الحقوق والمسؤوليات الرقمية"، والثامن "الصحة والسلامة الرقمية"، والتاسع" الأمن الرقمي" على أقل المتوسطات من بين باقي المحاور التسعة، وهذا مما يبرر إجراء مثل هذه الدراسة والدراسات المشابهة لها نظراً لأهمية وحساسية هذه المبادئ بالذات لتأثيرها القوى على الأمن الوطني والأمن والصحة الشخصية للمتعلمين، ولأن وجود ضعف في هذه القيم لدى الطلاب يجعلهم في موقع إلحاق الضرر بأنفسهم وبأوطانهم لاسمح الله ع- عدم وجود فروق بين الجامعات السعودية في درجة تعزيزها لمبادئ المواطنة الرقمية تبعاً لاختلاف العمر الزمني للجامعة، ويعزو الباحث لعدم وجود مساقات تعليمية تتولى تدريس مبادئ المواطنة الرقمية وبالتالي يؤثر عمر الجامعة وسياستها على بروز الغروقات في المعالجات والنتائج، كما يعزى ذلك لحداثة مصطلح المواطنة الرقمية وكونه من مستجدات هذه الحقبة ولم يأخذ وقته ولم يكتسب أهميته لدى الجامعات لذلك يتم التعرض لله فقط من خلال الاجتهادات الشخصية لعمادات شؤون الطلاب في بعض البرامج التوعوية والتدريبية السطحية. 
ץ- إجراء دراسة مقارنة تهدف للتعرف على أفضل حسان، فارس (ع ( ب). "المواطنة الرقمية"، مجلة كلنا مواطنون،.(151) التجارب العالمية في رفع درجة وعي المتعلمين بقيم حشيش، نسرين يسري (1/ (ب). "مهارات المواطنة

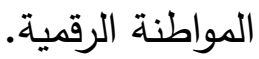

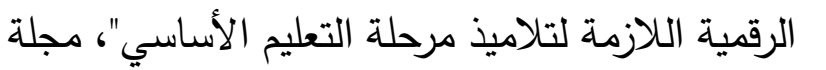
r- إجراء دراسة تهدف للتعرف على التحديات

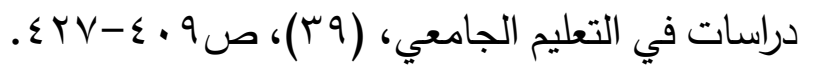
والمشكلات التي تواجه الجامعات السعودية في جانب التباء

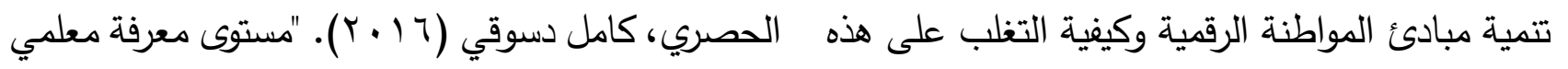
الدراسات الاجتماعية بأبعاد المواطنة الرقمية وعلاقتها ببعض المتغيرات"، المجلة العربية للدراسات التربوية والاجتماعية، السعودية(^). (1).

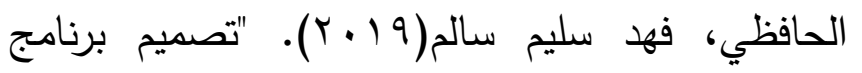
Black تعليمي قائم على نظام إدارة التعلم الإلكتروني

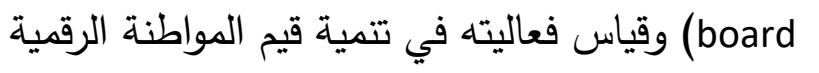
ومهارات التنكير التأملي لدى طلاب الكلية التقنية في مدينة جدة"، مجلة تكنولوجيا التربية-دراسات وبحوث-

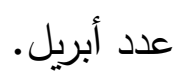

الاسوري، فؤاد .(2017) مستوى توافر معايير المواطنة

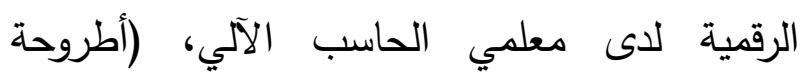

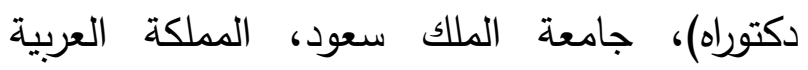

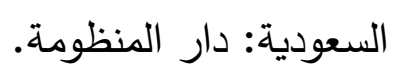
الدهشان، جمال على، والقويهي، هزاع بن عبد الكريم (10) (10. "المواطنة الرقمية مدخلاً لمساعدة أبنائنا على الحياة في العصر الرقمي"، مجلة البحوث النفسية

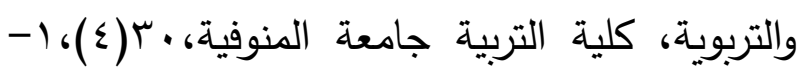
.

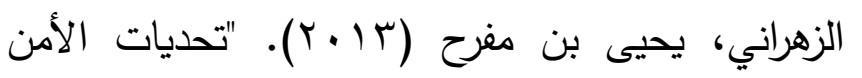
المعلوماتي في الثبكات الاجتماعية في المملكة الأسمري، شهد .(2015) المواطنة الرقمية وثقافة الاستخدام الأمن للإنترنت للكبار والصغار ، مركز تقنيات التعليم للطباعة والنشر • آل دحيم، فهر هذال، وآل دحيم، بريكان مسفر.

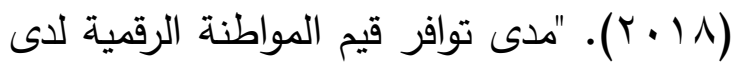
مدربي التدريب التربوي في مدينة الرياض: دراسة

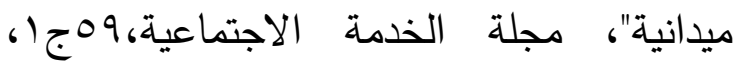
$. \varepsilon r V-r q q$ الجزار، هالة حسن بن سعد. (ع ا.بץ). "دور المؤسسات التربوية في غرس قيم المواطنة الرقمية: تصور مقترح"، دراسات عربية في التربية وعلم النفس، 385-418. 56 
وطرق التدريس الحاسب الآلي، كلية التربية جامعة

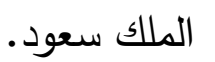
الطوالبة، هادي (Y V (Y). "المواطنة الرقمية في كتب التربية الوطنية والمدنية - دراسة تحليلية"، المجلة

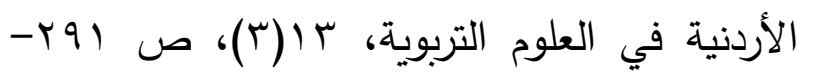
.$\Gamma \cdot \Lambda$ العجمي، محمد خميس (T 1 • ب). "المحاور السبعة في المواطنة الرقمية"، متاح على: المئي http://www.mediafire.com/file/rfl9m8lvdwnuu 4v/\%25D8\%25A7\%25D9\%2584\%25D9\%258 5\%25D8\%25AD\%25D8\%25A7\%25D9\%2588 \%25D8\%25B1_\%25D8\%25A7\%25D9\%2584 \%25D8\%25 العقاد، ثائرة عدنان محمد . (2017) تصور مقترح لتمكين المعلمين بمدارس وزارة التربية والتعليم الفلسطينية نحو توظيف منطلبات المواطنة الرقمية في التعليم، (رسالة ماجستير)، كلية التربية قسم أصول التربية، جامعة الأزهر ، غزة.

عبد القوي، حنان عبد العزيز (T ا • r). "المواطنة الرقمية لدة طلاب الجامعة بمصر : كلية البنات-جامعة عين شمس نموذجاً"، مجلة البحث العلمي في التربية،

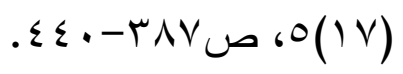

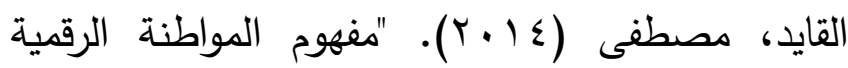
Digital Citizenship http://www.new-educ.com/definition-ofdigital-citizenship

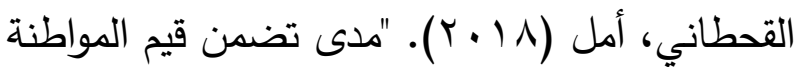
الرقمية في مقرر تقنيات التعليم من وجهة نظر أعضاء
العربية السعودية من منظور قانوني"، المجلة العزبية الدولية للمعلومات، جمعية كليات الحاسبات والمعلومات في الجامعات العربية، السعودية، ب(Y)،

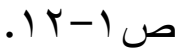
السليحات، روان يوسف، والفلوح، روان فياض، والسرحان، خالد على (1/ • Y). "درجة الوعي بمفهوم المواطنة الرقمية لدى طلبة مرحلة البكالوريوس في كلية العلوم التربوية بالجامعة الأردنية"، دراسات العلوم التزبوية، وقائع مؤتمر كلية العلوم التربوية " التعليم في الوطن العربي نحو نظام تعليمي متميز"،0؛ (ب). السيد، محمد (7 ( + ץ). "دور وسائل الإعلام الجديدة في دعم المواطنة الرقمية لدى طلاب الجامعة"، مجلة بحوث العلاقات العامة الشرق الأوسط،.(12) شرف، صبحي شعبان، والدمرداش، محمد السيد

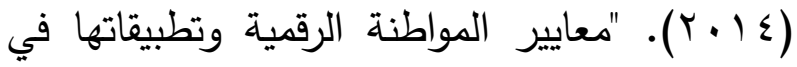
المناهج الدراسية"، المؤتمر السنوي السادس للمنظمة العربية لضمان الجودة في التعليم، كلية التربية جامعة

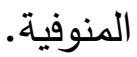

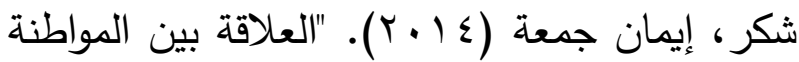
الإكترونية وتثكيل هوية الأنا للمراهقات"، مجلة

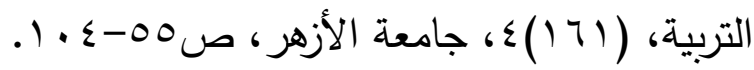
الشمري، حمدان •(2016) مدى توافر قيم المواطنة

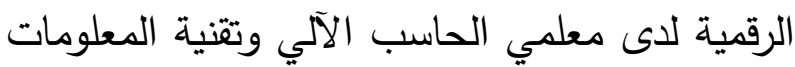
في المرحلة المتوسطة والثانوية في محافظة حفر الباطن، (رسالة ماجستير غير منشورة) قسم المناهج 


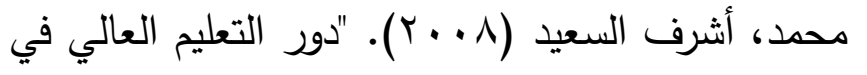
مواجهة تحديات تأسيس مجتمع المعرفة في مصر"،

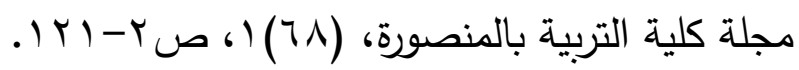

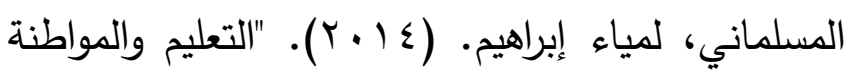
الرقمية: رؤية مقترحة"، عالم التربية،(47) 15 ،-15 إناء

94.

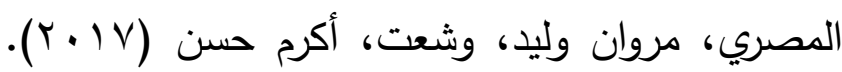

"مستوى المواطنة الرقمية لدى عينة من طلبة جامعة ولمدية

فلسطين من وجهة نظرهم"، مجلة جامعة فلسطين

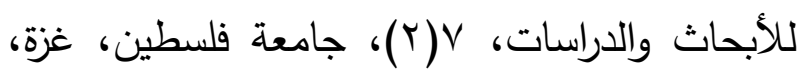

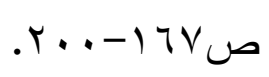

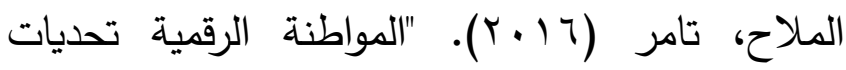
وآمال"، مجلة كلية التربية جامعة الإسكندرية.

\section{المراجع الأجنبية:}

Alberta Education. (2012). Digital Citizenship Policy Development Guide.

Breslau, J., Aharoni, Pedersen, E. R., \&Miller, L. L. (2015). "Areview of research on problematic internet use and well-being". Santa Monica: Rand Corporation.

Berardi,R.(2016). Elementary teachers' perceptions of value and efficacy regarding the instruction of digital citizenship. Unpublished master thesis, Immaculate University

Choi, M., Glassman, M., \&Cristol, D. (2017)."What it means to be a citizen in the internet age: Development of a reliable and valid digital citizenship scale". Computers \& Education, 107, 100-112.

Dotterer, G., Hedges, A., Parker, H. (2016). "Fostering Digital in the Classroom", Education Digest Journal, 82(3), Vilnius, Lithuania, P.58-63.
هيئة التدريس"، مجلة الجامعة الإسلامية للدراسات

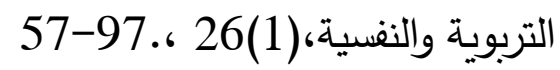

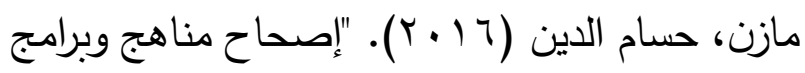

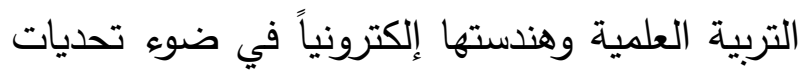
ما بعد الحداثة والمواطنة الرقمية"، المؤتمر العلمي لهي الثامن عشر (مناهج العلوم بين المصرية والعالمية)،

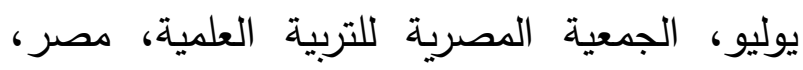
ص ص D R المجالي، فايز (V V . . r). "استخدامات الانترنت وتأثيره على العلاقات الاجتماعية لدى الشباب الجامعي:

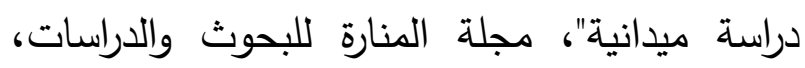

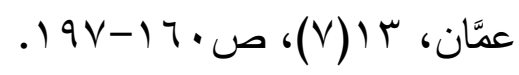

Eurydice. (2013). Citizenship education at school in Europe. Eurydice. The information network on education in Europe. Cambridge: Cambridge University Press.

Froehlich, D. (2012). NCTA Web 2.0: "Passport to Digital Citizenship. Participant Manual". North Caroli na Teacher Academy.

https://translate.google.com.sa/translate?hl=ar \&sl=en\&u=http://wikieducator.org/Digital Citizenship\&prev=search.

Isman, A., Canan G. (2014). "Digital citizenship". Turkish Online Journal of Educational Technology-TOJET, 13(1), 7377.

Klute, E. (2017). "Intercultural digital citizenship in the community". Mira Media. Available at: http://www.miramedia.nl/media/file .

NetSafe. (2013). "Digital Citizenship", Retrieved on November 2, 2015, Available at: 
Ohler, J. (2011). Digital Community, Digital Citizen. Thousand Oaks: Corwin Press Inc. Preddy, L. (2016). "The Critical Role of the School Librarian in Digital Citizenship Education", Knowledge Quest, 44(4), Knowledge Quest Academy, Colorado, USA, pp.4-5.

Ribble, M; Bailey, G; \& Ross, T. (2004). Digital citizenship: Addressing appropriate technology behavior. Learning \& Leading with Technology, 32 (1), 6- 12.

Ribble, M., Bailey, G. (2006). Digital citizenship. At all grades levels.
Ribble, M. (2011). "Digital Citizenship in Schools" (2nd ed.). International Society for Technology in Education. U.S. \& Canada. Thompson, P. (2013). "The digital natives as learners: Technology use patterns and approaches to learning". Computers \& Education, 65(1), 12-33.

Wang, X., Xing, W. (2018). "Exploring the influence of parental involvement and socioeconomic status on teen digital citizenship: A path modeling approach". Journal of Educational Technology \& Society, 21(1), 186-199. 


\title{
The role of Saudi universities in promoting the values of digital citizenship (an analytical study of the websites of Saudi universities).
}

\author{
Zafer Ahmed MUSLEH Algarni \\ Associate Professor of Education Technology \\ College of Education - Zulfi \\ Majmmah University - KSA
}

\begin{abstract}
Saudi universities in promoting the values and principles of digital citizenship among its students by analyzing all that were published on the official electronic pages of universities or the so-called "university official website". The study also aimed to reveal the highest values of digital citizenship and the lowest percentage of the universities 'degree of care by publishing them through their electronic pages, and looking for the existence of differences in that according to the difference in the chronological age between one university and another. To analyze the electronic pages of universities, the researcher relied on a special card that he prepared to achieve the goals of the study, as this card included the nine main elements of digital citizenship principles, through which a number of sub-value for each element was deduced and the number after the arbitration was settled by specialists at (58) values for digital citizenship. Then, the researcher applied it on the official pages of Saudi public universities on the Internet, which amount to (30) universities in the academic year $1441 \mathrm{AH}$; As it was divided according to the chronological age into three groups (old universities - middle-aged (modern) universities - emerging universities). The results of the study showed that three of the principles of digital citizenship outperformed the remaining nine, which are, the first principle called "digital access", the third "digital communication" and the fifth "digital etiquette (fluency)" and this embodies the great interest of Saudi universities in promoting the elements of these principles among their students. Also, the results proved the absence of statistically significant differences attributed to the difference in the chronological establishment age between Saudi universities in their contributions to promote the values and principles of digital citizenship. The study recommended universities to take care of the less promoted elements of digital citizenship, which are represented in the principles of "digital security" and "digital health and wellness", also, recommended universities to create courses for digital citizenship, train university professors on integrating the principles of digital citizenship into the curriculum, conduct more studies on the contributions of Saudi universities in Promoting the values of digital citizenship through various social media channels such as: Twitter, Facebook, Snapchat... and to conduct more studies on practical proposals and programs through which the role of universities in spreading the principles of digital citizenship in Saudi society at all its levels can be promoted.

Key words: (digital citizenship - digital access - digital commerce - digital communication - digital illiteracy - digital etiquette - digital laws - digital rights and responsibilities - digital health and wellness digital security).
\end{abstract}

